\title{
WestVirginiaUniversity
}

THE RESEARCH REPOSITORY @ WVU

Graduate Theses, Dissertations, and Problem Reports

2017

\section{Steam generation by solar and natural gas generators for thermal enhanced oil recovery}

Abha Dwivedy

Follow this and additional works at: https://researchrepository.wvu.edu/etd

\section{Recommended Citation}

Dwivedy, Abha, "Steam generation by solar and natural gas generators for thermal enhanced oil recovery" (2017). Graduate Theses, Dissertations, and Problem Reports. 3990.

https://researchrepository.wvu.edu/etd/3990

This Problem/Project Report is protected by copyright and/or related rights. It has been brought to you by the The Research Repository @WVU with permission from the rights-holder(s). You are free to use this Problem/Project Report in any way that is permitted by the copyright and related rights legislation that applies to your use. For other uses you must obtain permission from the rights-holder(s) directly, unless additional rights are indicated by a Creative Commons license in the record and/ or on the work itself. This Problem/Project Report has been accepted for inclusion in WVU Graduate Theses, Dissertations, and Problem Reports collection by an authorized administrator of The Research Repository @ WVU. For more information, please contact researchrepository@mail.wvu.edu. 


\title{
Steam Generation by Solar and Natural Gas Generators for Thermal Enhanced Oil Recovery
}

\author{
Abha Dwivedy \\ Problem Report Submitted \\ to the College of Engineering and Mineral Resources \\ at West Virginia University \\ in Partial Fulfillments of the Requirements \\ for the Degree of \\ Masters of Science in \\ Petroleum and Natural Gas Engineering \\ Dr. Kashy Aminian, Chair \\ Dr. Radhey Sharma, Co-Chair \\ Prof. Sam Ameri, Committee Member \\ Dr. P.V. Vijay, Committee Member \\ Department of Petroleum and Natural Gas Engineering
}

Morgantown, West Virginia

2017

Keywords: Solar Steam Generator, Natural Gas Steam Generator, Thermal Enhanced Oil Recovery Copyright 2017 Abha Dwivedy 


\title{
Abstract \\ Steam Generation by Solar and Natural Gas Generators for Thermal Enhanced Oil Recovery
}

\begin{abstract}
Abha Dwivedy
With easy oil recovered all across the world, the oil fields are depleting and extraction of heavy oil is becoming more important. The exploration and drilling of new fields is expensive and time intensive. With most of the oil remaining is heavy and viscous; Enhanced Oil Recovery (EOR) methods are followed. Thermal EOR is the most widely used method in which steam injection is the most popular. Every year natural gas is burnt to produce steam and this amount is increasing as heavy oil reserves are developing all across the world. With increase in technological advancements and goal of reducing carbon emissions, solar energy is used to produce steam for the injection. This technology is called solar wells. The main objective is highlighting the cost of steam produced by natural gas and solar wells and finding investment, installation, operation and maintenance costs of these generators. Further, analyzing these costs, recommendations are made if new technology (solar wells) is worth the investment.
\end{abstract}




\section{Acknowledgements}

I would like to take this opportunity to thank all the important people who made me successfully accomplish my problem report by supporting me in every way. First and foremost, I would like to thank my parents for being there, encouraging me and believing in all my decisions. I would like to dedicate this to them as they worked really hard to make sure I had quality education and living.

Dr. Radhey Sharma, I would like to thank you for giving me the opportunity to work as Graduate Service Assistant and simultaneously helping me with my research and funding. In these past 2 years, you have guided me to achieve my best. I am really appreciative of what I have learnt from you and without your support, this wouldn't have been possible. I would like to sincerely express my gratitude to Dr. Kashy Aminian for giving me the opportunity to work under him and patiently answering all my questions. I have learnt a lot from all your classes, which will help me progress in my career and I am extremely grateful. Prof. Sam Ameri, I cannot thank you enough for talking to me every time I stopped by your office no matter how busy you were. Thanks for all your support and help.

Special thanks to Leslie Van Zant, Kimberly Baker, Maggie Tang, Dr. John Zaniewski and Dr. Hema Siriwardane for an amazing work place environment. I have learnt a lot from working with all of you and I am genuinely appreciative.

In addition, I would like to acknowledge all my friends for uplifting my spirit. Thanks to Anirudh Tirunahari, Valentina Jami, Garrett Rinker, Olivia Theurer, Ikttesh Chahal, Chitrangi Doshi, and Rasik Pondicherry. 


\section{Table of Contents}

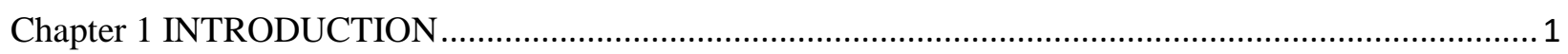

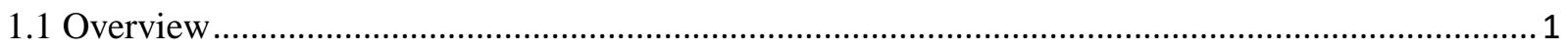

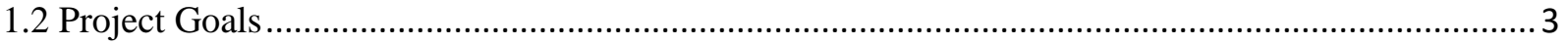

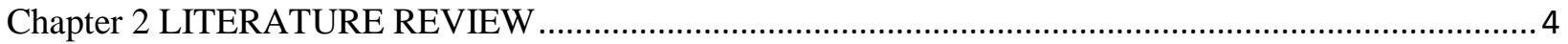

2.1 Concept of Thermal Enhanced Oil Recovery …......................................................................... 4

2.1.1 Factors Affecting Thermal Enhanced Oil Recovery .......................................................... 4

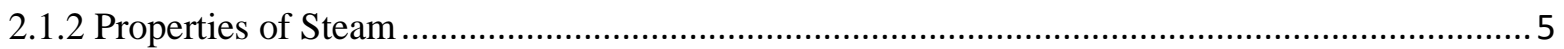

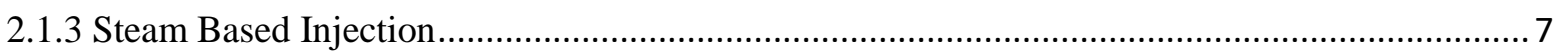

2.2 Solar Generator for Thermal Enhanced Oil Recovery ................................................................ 13

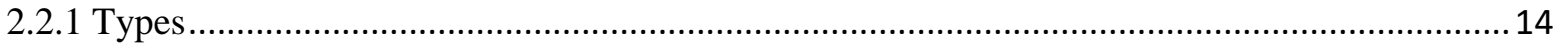

2.3 Natural Gas Generator for Thermal Enhanced Oil Recovery ….................................................. 15

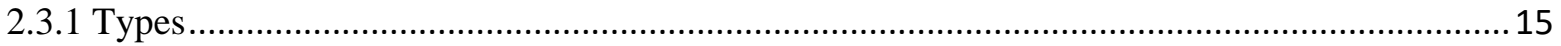

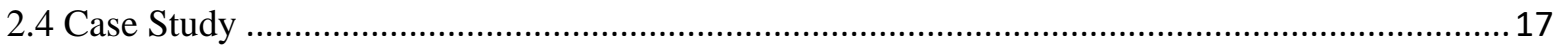

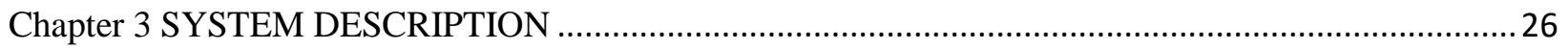

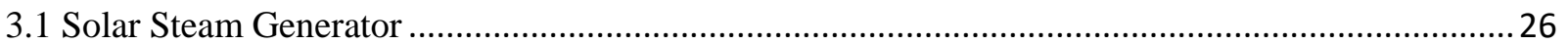

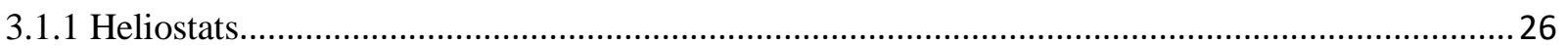

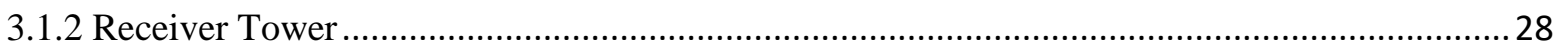

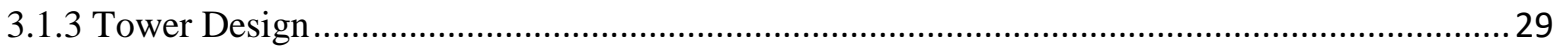

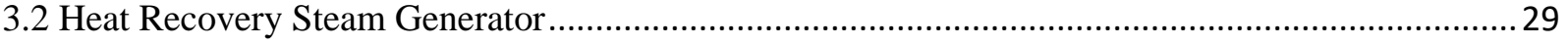

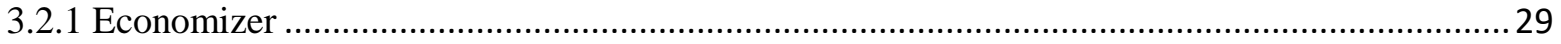

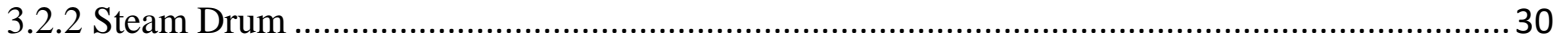

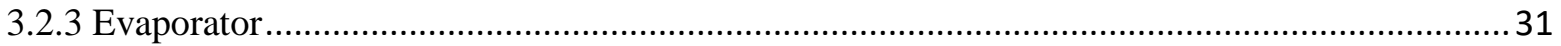

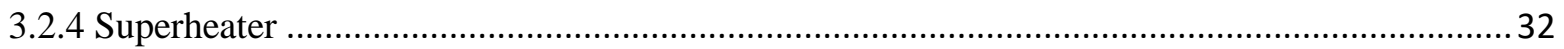

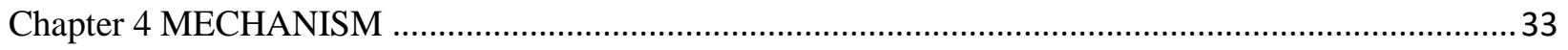

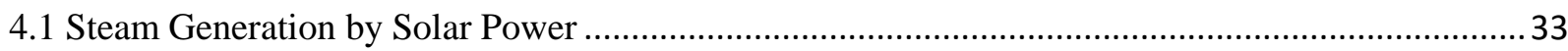

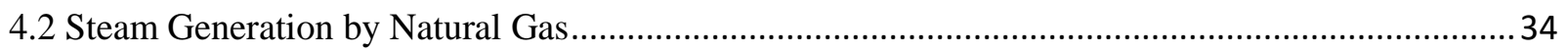

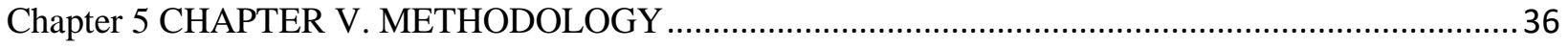

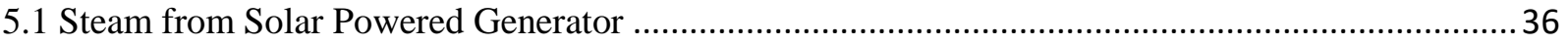

5.2 Steam from Natural Gas Powered Generator.................................................................................. 36

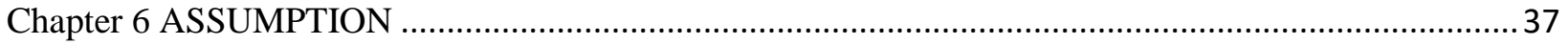

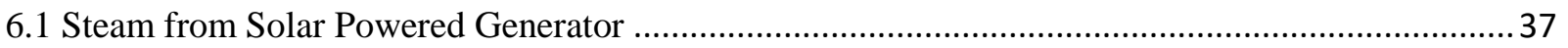

6.2 Steam from Natural Gas Powered Generator..................................................................................... 37 


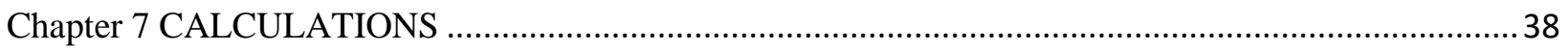

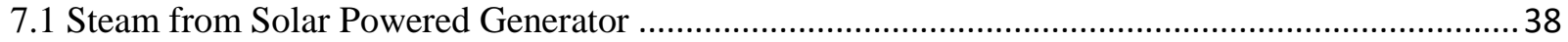

7.2 Steam from Natural Gas Powered Generator......................................................................... 41

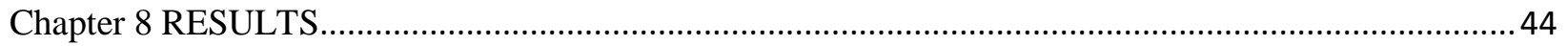

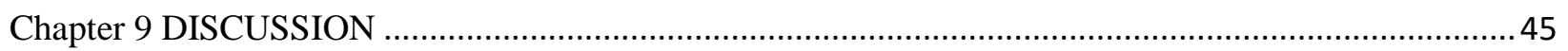

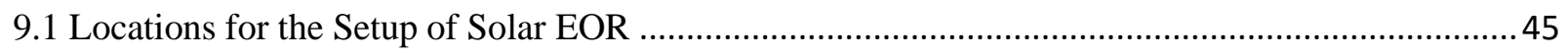

9.2 Advantages of Solar Enhanced Oil Recovery .........................................................................50

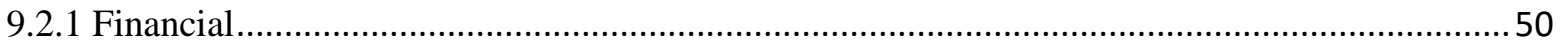

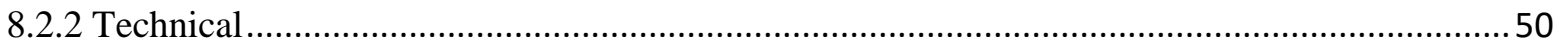

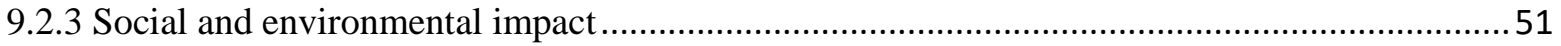

9.3 Disadvantages of Solar Enhanced Oil Recovery …..................................................................51

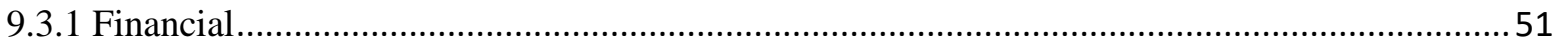

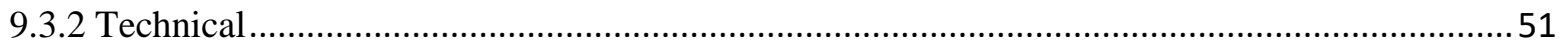

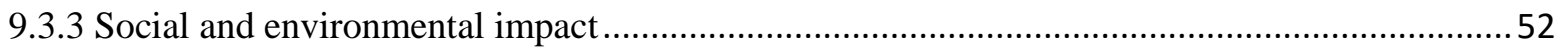

9.4 Advantages of Natural Gas Enhanced Oil Recovery ...............................................................52

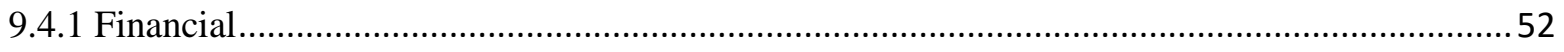

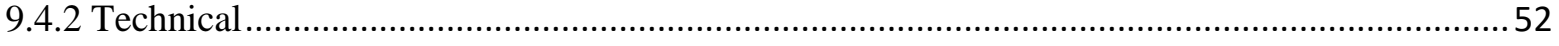

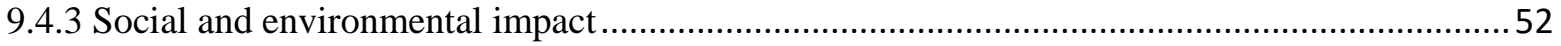

9.5 Disadvantages of Natural Gas Enhanced Oil Recovery...............................................................52

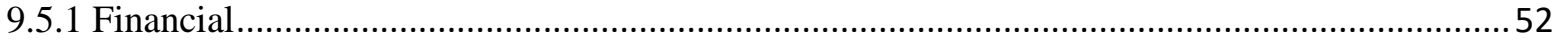

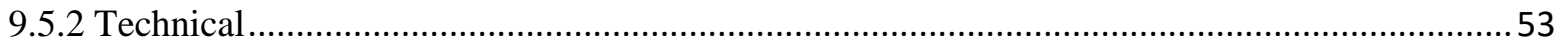

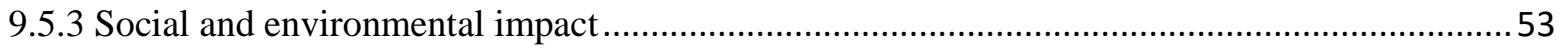

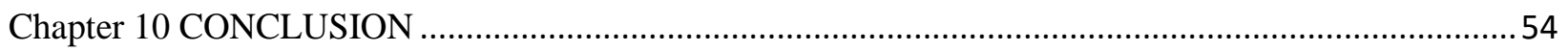




\section{List of Figures}

Figure 1-1 Global Heavy Oil Resources, Barrels in Place [5] .........................................................

Figure 1-2 Variety of Viscous Oils for Different Countries [5]......................................................... 2

Figure 2-1 Viscosity of Different Oils at Different Temperatures [10] ..................................................... 4

Figure 2-2 Steam Chest and Heated Oil Zones in Steam Drive [18] ..................................................... 6

Figure 2-3 Heat Content of Boiling Water and Saturated Steam at Different Pressure ............................. 7

Figure 2-4 Different Process Steps in Cyclic Steam Simulation ........................................................ 9

Figure 2-5 Steam Process After Initial Cycle [21] ..................................................................... 11

Figure 2-6 Cross Section of Steam Assisted Gravity Drainage [22].................................................... 12

Figure 2-7 Conceptual diagram of the SAGD process [25] ............................................................ 13

Figure 2-8 Once Through Steam Generators [35]......................................................................... 16

Figure 2-9 Cross Section of Heat Recovery Steam Generator [34] ....................................................16

Figure 2-10 Different Areas of Operation by Aera Energy [42] ....................................................... 17

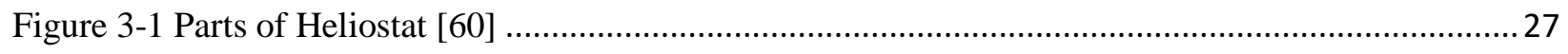

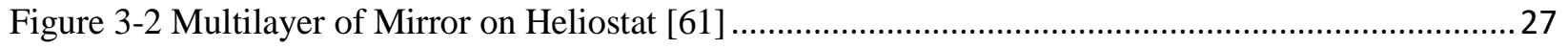

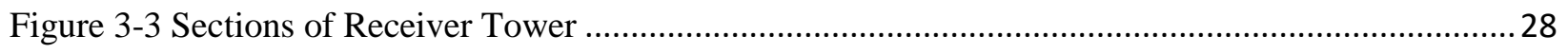

Figure 3-4 Side Section and Cross Section of Economizer [64] [65] ................................................... 30

Figure 3-5 Cross Section of Steam Drum [66] …......................................................................... 31

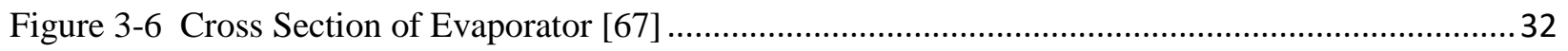

Figure 3-7 Cross Section of Super Heater [68] [69] ....................................................................... 32

Figure 4-1 Solar Steam Generation Mechanism ............................................................................. 33

Figure 4-2Heat Recovery Steam Generation Mechanism [71] ......................................................... 34

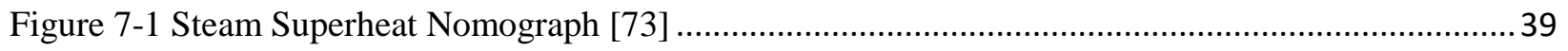

Figure 9-1 Global Heavy Oil Resources in Barrels in Place............................................................... 45

Figure 9-2 Global Heavy Oil Resources in Barrels in Place by Country [5] ......................................... 45

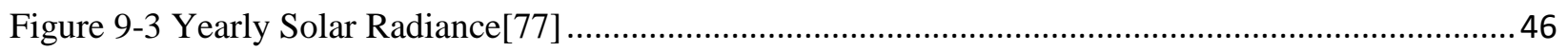

Figure 9-4 Average Minimum and Maximum Temperature in San Francisco, U.S.A .............................46

Figure 9-5 Average Monthly Sun hour in San Francisco, U.S.A [78] ...................................................47

Figure 9-6 Average Minimum and Maximum Temperature in Tumeremo, Venezuela .............................47

Figure 9-7 Average Monthly Sun hour in Tumeremo, Venezuela[79] .................................................47

Figure 9-8 Average Minimum and Maximum Temperature in Riyadh, Saudi Arabia .............................. 48

Figure 9-9 Average Monthly Sun hour in Riyadh, Saudi Arabia[80] .................................................. 48

Figure 9-10 Average Minimum and Maximum Temperature in Bagdad, Iraq ......................................48

Figure 9-11 Average Monthly Sun hours in Bagdad, Iraq[81] ......................................................... 49 


\section{List of Tables}

Table 1-1 Classification of Different Heavy Oil based on API Gravity and Viscosity [5]........................ 1

Table 2-1 EOR production at Different AREA Energy Fields [43] .................................................... 18

Table 2-2 Additional Fields of EOR Operation by AERA Energy [43] ................................................... 18

Table 2-3 Different Operations at Midway Sunset, AERA Energy …................................................... 19

Table 2-4 Different Operations at South Bellridge, AERA Energy …..................................................20

Table 2-5 Summary of Cogeneration in California Fields [43] ............................................................ 21

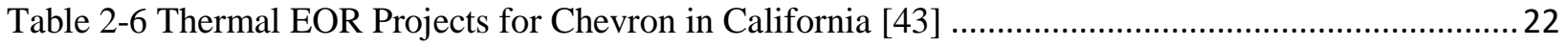

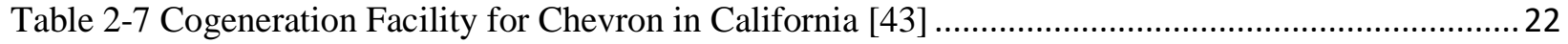

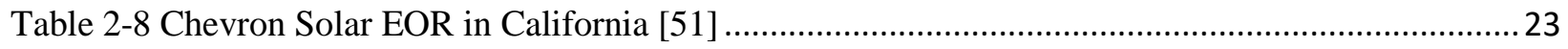

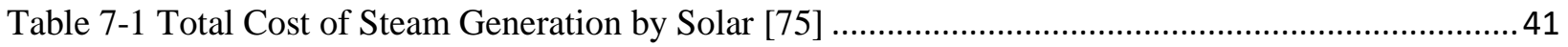

Table 7-2 Energy Content and Combustion Efficiency of Fuels [76].................................................. 41

Table 7-3 Total Cost of Steam Generation by Natural Gas [75] [76] .................................................. 42

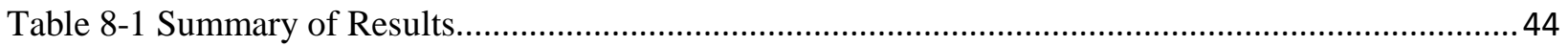




\section{Chapter 1 INTRODUCTION}

\subsection{Overview}

With the recent decline in the prices of oil that further lead to decline in domestic production and increase in imports, the field growth of the petroleum reserves cannot be overemphasized. To optimize reservoir development for better economic returns, reservoirs are periodically assessed for the hydrocarbon reserves. Field growth of existing fields by enhanced oil recovery (EOR) methods are crucial as they contribute to $90 \%$ of the additional reserves in the U.S. [1]. The primary recovery of reservoirs consists of natural flow and artificial lift, resulting in an oil recovery of only 5-15\%. Upon dissipating natural pressure, secondary recover is carried out by injecting fluids; this target to an additional recovery of 30\%. Tertiary recovery consists of thermal EOR, chemical EOR and gas injection, which increases the oil recovery to more than $80 \%$ [2]. Total world crude oil resources account for around 9-13 trillion bbl. out of which two-third are heavy oil and bitumen deposits. Heavy oil has higher density, higher specific gravity and higher viscosity compared to conventional oil. The oil resources all around the world as per IEA (International Energy Agency) have 30\% of conventional oil, 15\% of heavy oil, 30\% of bitumen and oil sand, and $25 \%$ of extra heavy oil. The viscosity of oil is generally described by the API gravity [3].

American Petroleum Institute developed API gravity, which is used to measure the relative density of various petroleum liquids. With lower API number, higher is the specific gravity and heavier is the oil [4]. The table below distinguishes the heavy oil, extra heavy oil and bitumen as per $12^{\text {th }}$ world petroleum congress.

\begin{tabular}{|l|l|l|}
\hline & API Gravity & Viscosity \\
\hline Heavy Oil & $10^{\circ}-22.3^{\circ}$ & $100-10,000$ \\
\hline Extra Heavy Oil & $<10^{\circ}$ & $100-10,000$ \\
\hline Bitumen & $<10^{\circ}$ & $>10,000$ \\
\hline
\end{tabular}

Table 1-1 Classification of Different Heavy Oil based on API Gravity and Viscosity [5]

Heavy oil compared to conventional oil has higher level of Sulphur. The lighter fractions are eradicated through natural processes. With higher proportion of asphaltic molecules and substitution of carbon network with nitrogen and oxygen, oil density increases [6]. The global heavy oil resources represented by barrels in place are shown in the figure below- 


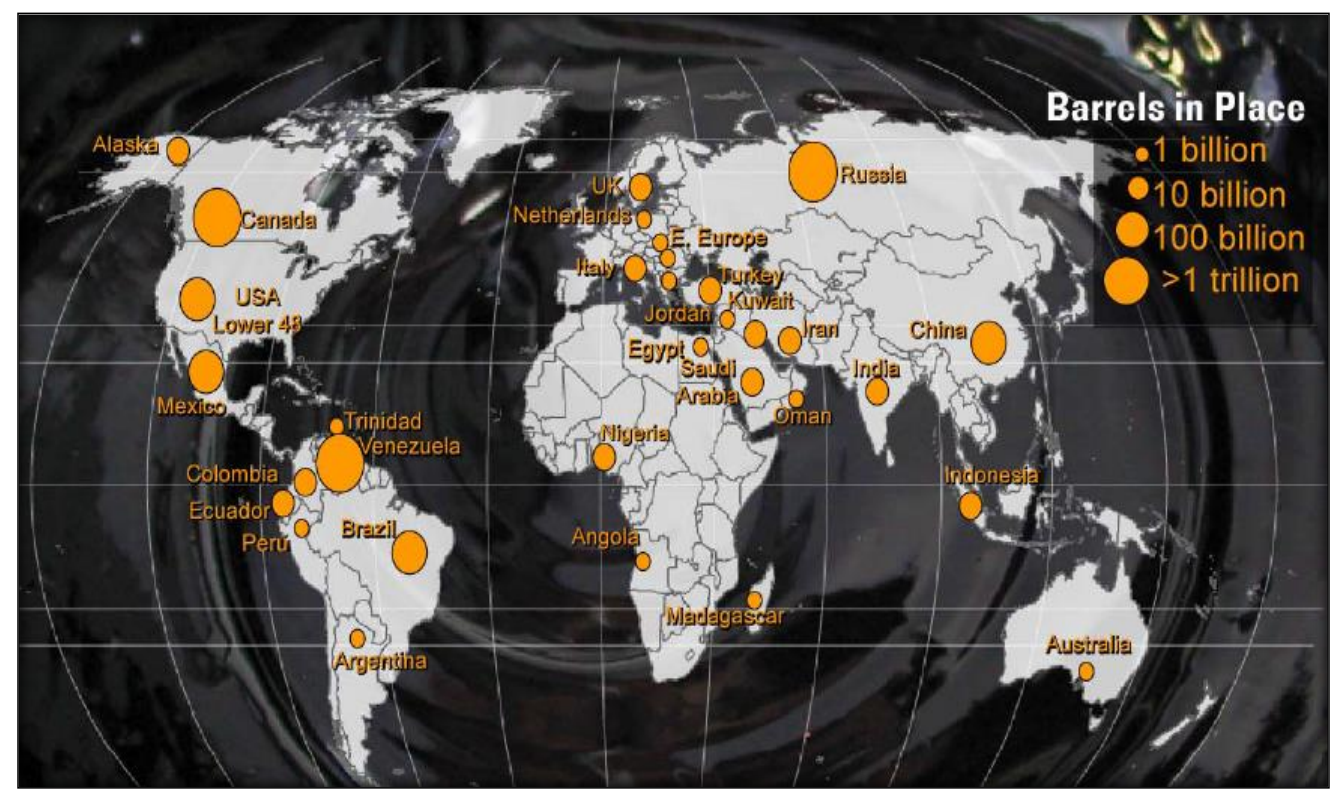

Figure 1-1 Global Heavy Oil Resources, Barrels in Place [5]

The total worldwide estimate of heavy hydrocarbon is 5.5 trillion barrels and four-fifth of these deposits is found in the western hemisphere. The oil supply can be improved if heavy oil and natural bitumen reserves are recovered [7]. Furthermore, the variety of these viscous oil with respect to API gravity for different countries are represented in the figure below-

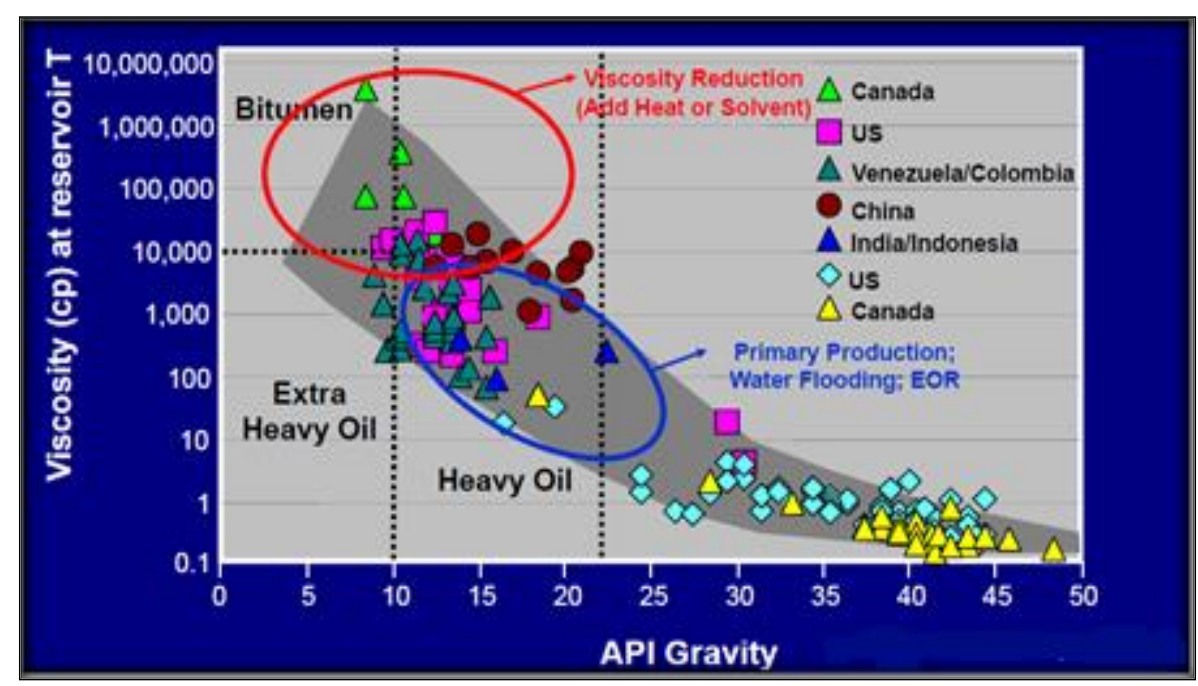

Figure 1-2 Variety of Viscous Oils for Different Countries [5]

The thermal recovery process is divided into two types, steam based and combustion based. This research focuses on steam based injection which further consists of cyclic steam simulation (CSS), steam flooding, and steam assisted gravity drainage (SAGD) [8]. The new technological development in Thermal Enhanced Oil Recovery is solar powered oil field that 
uses solar energy to heat water and convert it into steam. This steam is then injected into the wells for enhanced oil recovery.

\subsection{Project Goals}

This project focuses on the production of steam by Solar Steam Generator (SSG) and Heat Recovery Steam Generator (HRSG) for Thermal Enhanced Oil Recovery (TEOR), used by major oil companies. As SSG is a new technology in the petroleum market, the goal of this project is to lay some light on the cost of steam produced by two different generation systems and additionally analyze investment, installation, operation and maintenance cost of these generators. As the price of natural gas fluctuates from different countries to different time frame, range of natural gas prices is observed to further calculate the cost of steam. This range is compared to steam generated by SSG. Based on the heavy oil reserves and annual solar radiance, most suitable locations are proposed, where SSG is suitable to operate. Finally, with this project, recommendations are made to oil companies, if this new technology (SSG) is worth the investment, considering both advantages and disadvantages. 


\section{Chapter 2 LITERATURE REVIEW}

\subsection{Concept of Thermal Enhanced Oil Recovery}

As heavy oil is viscous and hard to flow, Thermal Enhanced Oil Recovery (TEOR) is carried out. Depending on the reservoir, API gravity of heavy oil is usually less than 20 degree and external heat is required for its production [8]. The process of thermal recovery is divided into two types firstly, hot fluid recovery in which fluid such as steam is injected in the reservoir and secondly, combustion recovery process in which the heat is generated within the reservoir. This project focuses on steam based injection as it is the most commonly used method. The injection of steam lowers the viscosity of oil as the crude oil is heated and thereby vaporizing the oil to increase the mobility and production. Furthermore, this effect reduces the surface tension, increases the permeability and improves the seepage condition of the reservoir. In shallow reservoirs, steam injection is the most economical way to obtain high viscosity crude. Some examples of shallow reservoir include San Joaquin Valley of California, oil sand of Alberta, Canada etc. [9].

\subsubsection{Factors Affecting Thermal Enhanced Oil Recovery}

The factors affecting the recovery of oil include viscosity reduction, steam distillation, thermal expansion, relative permeability, steam drive and alteration in capillary pressure.

\subsubsection{Viscosity}

The viscosity reduces with the change in temperature as shown in the figure below.

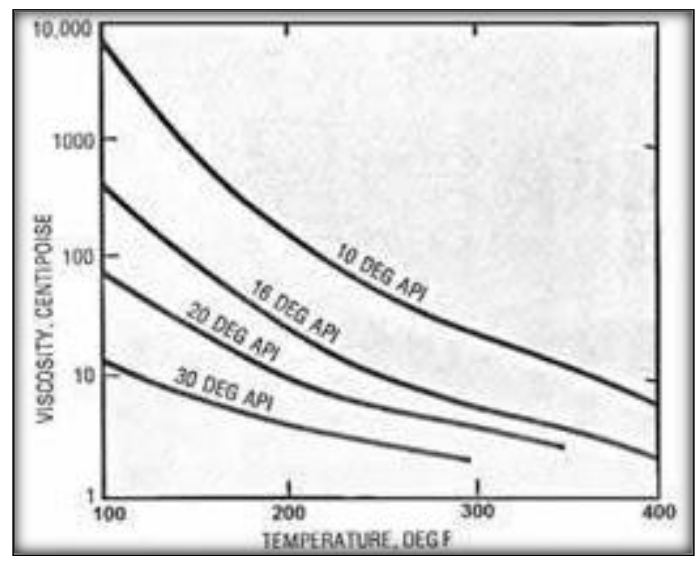

Figure 2-1 Viscosity of Different Oils at Different Temperatures [10]

The effect of temperature on viscosity depends on volatility, nature and composition of oil. With increase in temperature, the macromolecular structure of crude oil changes, causing monomers to be scattered. This results in improved flow property and decreased oil flow 
resistance [11]. The viscosity reduction is explained by mobility ratio that is the ratio of effective permeability to viscosity [12]. Viscosity measures the resistance of oil to flow. With higher viscosity of oil, greater pressure drop is required to move oil through sand. As viscosity of water in formation and injection well is identical and lower than that of crude oil, it flows more readily through sand and pushes oil towards production well. The API gravity is measured for every kind of crude oil as it correlates to physical properties [13]. The equation below highlights the importance of change in viscosity to pore scale capillary effect. The $v$ represents interstitial velocity, $\mu$ is fluid viscosity and $\gamma$ is interfacial tension (IFT) between the displaced and displacing fluid. When pore scale capillary effect increases, viscosity also increases however, interfacial tension decreases.

$$
C a=\frac{v \times \mu}{r}[14]
$$

\subsubsection{Steam Distillation}

With high temperature steam, lighter fraction of crude oil is vaporized and this process is known as steam distillation. These lighter hydrocarbons are carried by the steam, combustion gas, hot water and distilled solvents in front of the combustion front, towards the production well [15]. Steam distillation is a critical function responsible for gravity segregation of fluids and low residual oil saturations in porous media. Through distillation process, oil composition has greater effect on efficiency of oil recovery than API gravity [16].

\subsubsection{Relative Permeability Alteration}

The relative permeability of oil, water and gas can be affected by high temperature and pressure of steam. The temperature can be altered by interfacial tension (IFT) between flowing phases or altered by the wettability of porous material. With increase in temperature, IFT between oil and water decreases and the wettability can shift to oil wet or water wet condition depending on fluids in the reservoir and porous media chemical composition. The IFT should be equal or less than $0.1 \mathrm{dyne} / \mathrm{cm}$ for relative permeability to be substantial and this is possible with light oil at very high temperature [17].

\subsubsection{Properties of Steam}

The steam injected through injection well is a mixture of vapor and liquid. The weight fraction of vapor is called steam quality. As vapor can sustain more energy that liquid, quality of steam is better if it has more amount of vapor. The heat from the steam heats cap rock, reservoir rock and base rock. At the initial step, hot vapor rises up due to low density and steam chest is 
formed at the top of the reservoir. As oil drains downwards, the saturation reduces to approximately 5\%. The condensed water and low viscous oil drains towards the production well and heats the high viscous oil at the bottom. The hot water displaces oil at the bottom of the reservoir. As water has lower energy than vapors and is more viscous, it moves slower than steam and leads to low effectiveness of oil production. Thus, gravity affects fluids more at the top of the reservoir than at the bottom.

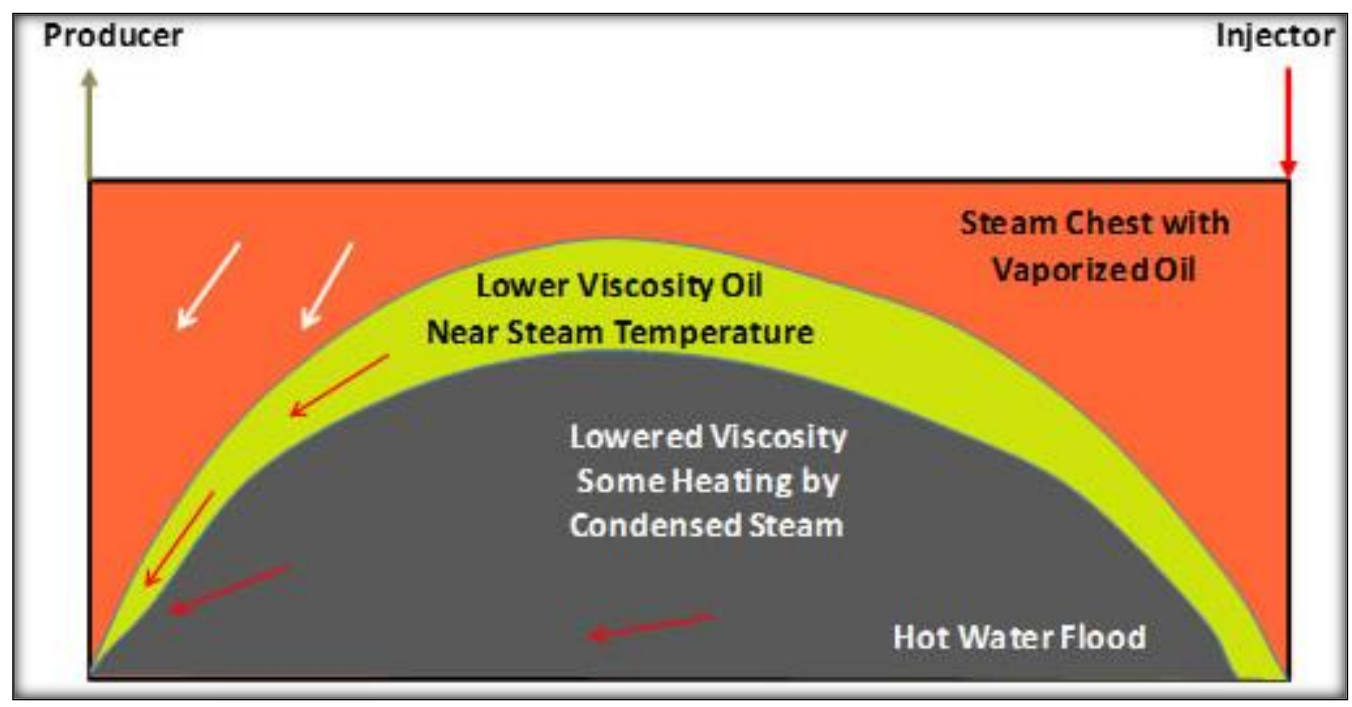

Figure 2-2 Steam Chest and Heated Oil Zones in Steam Drive [18]

The water carries very large amount of heat per unit mass as it has highest specific heat and lateral heat of vaporization than any other fluid. The variation of boiling water and dry saturated steam is shown in the figure below. The lateral heat of vaporization is the difference between two curves and is higher at low pressure. It reduces to zero at $705^{\circ} \mathrm{F}$ and 3206 psia, which is the critical point. Steam carries more heat than hot water at 100 to 1500 psia, where most of the projects operate. 


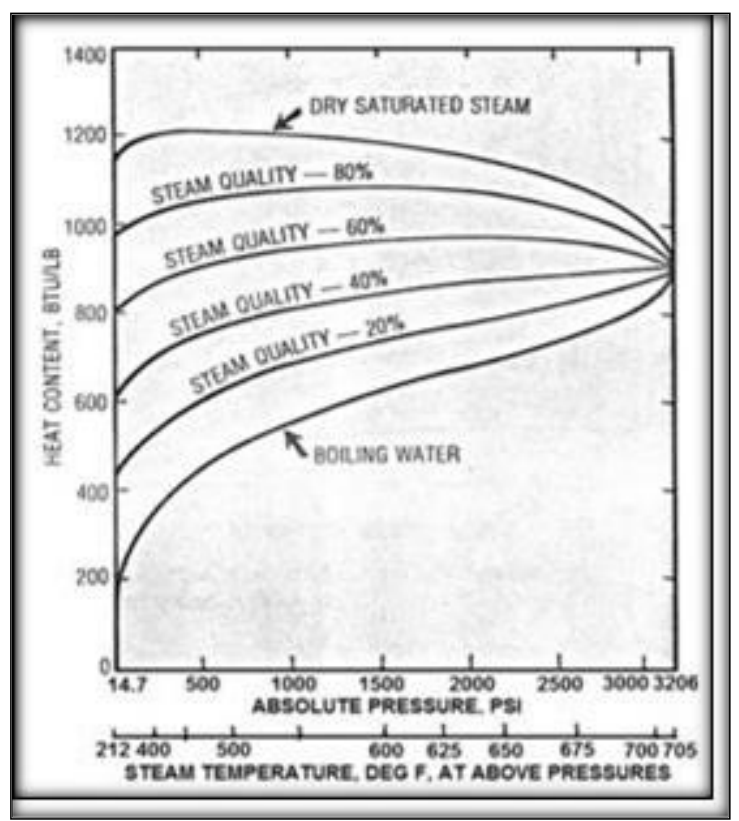

Figure 2-3 Heat Content of Boiling Water and Saturated Steam at Different Pressure

Steam temperature increases with increase in pressure. At lower pressure, steam injection applications have low heat loss as heat loss decreases with low temperature. Additionally, deeper high pressure reservoirs and low permeability reservoirs experience higher heat loss as they require high injection pressures. Steam heats the formation when it gives up it lateral heat at constant temperature to turn into water. If the lateral heat is higher, steam can remain at higher temperature to heat the subsurface formations to move through the reservoir. From the above figure, the average condition of $80 \%$ quality steam required for injection is 450 degree Fahrenheit and 414.7 psia [10].

\subsubsection{Steam Based Injection}

The steam simulation process is applied to viscous oil and involves injection of steam into the reservoir through injection wells. To force the steam into the reservoir, the injection pressure must exceed the formation pressure. After the injection process, the reservoir is left for soak in period before oil is pumped out from the production well. The injected steam reduces the viscosity of heavy oil, making it easier to flow. Steam stripping is a process which removes larger fraction of crude oil by removing low boiling point liquids from heavy oil. With this process the constituents of oil remain the same with heavy components in the reservoir and favorable lighter fractions recovered from the production well. Upon the condensation of steam, stripped components condense to form solvent and increase the displacement efficiency. The 
steam distilled is composed of naphthenic and aromatic components, which acts as a good solvent to oil. The paraffin aids the deposition of asphaltic component in front of steam, thereby restricting the oil flow from production well. Low recovery of the heavy oil can be caused by the shrinkage of the volatile condensing front as steam continues to pass. As the volatile constituent increases in the conventional oil from residual oil, the recovery rate decreases. The process of stripping, distillation and condensation of steam in general increases the rate of recovery favorably more than just the reduction of viscosity alone. The process of the injection from one or more well is called steam drive and this technique is effective for the recovery of heavy oil that has little success rate due to the difficulty of making a connection between production and injection well. When the flow path is heated, the steam moves to the oil zone and the oil drains towards the production well. If the well is poorly insulated or when the injection rate is low, hot fluid suffers a great heat loss. The temperature of non-condensable injected fluids is lower than that at the wellhead, causing the vapors to condense due to the heat loss. As heat is not maintained in steam, oil comes in contact with the hot water instead of steam. This can have an adverse effect on the initiation and rate of growth of steam zone and thereby on the recovery rate of the oil [19].

\subsubsection{Cyclic Steam Stimulation}

The cyclic steam simulation/injection (CSI) is a type of the steam based thermal recovery that uses viscosity reduction, gas expansion and wettability alteration. This process is applied to both heavy oil and light oil reservoir and was first introduced in late 1950s. To further increase the effectiveness, this process includes chemical additives, introduced in the horizontal wells and implemented in with hydraulic fracturing. The advantage of this method is that it gives quick payoff with high success rate. With respect to other steam recovery methods such as steam flooding (50-60\% OOIP) and SADG (60-70\% OOIP), this is less competitive. This process is also referred to as "huff-and-puff" as it involves periodic steam injection. One well is used as injector and producer with three stages of the cycle including injection, soaking and producing. Upon injection of steam into the well for certain period of time, temperature in the surrounding reservoir rises (200-300 degree Celsius under $1 \mathrm{MPa}$ of injection pressure). After the desired amount of steam is injected, the well is shut down to soak the steam for not more than few days. After the well is opened, the oil flows out with the built in pressure and then by artificial lift. This process of injecting, soaking, and producing is repeated until desired economic level is 
achieved [20]. The recovery factor for CSI ranges from 20 to $35 \%$ and minimum depth for this method is $1,000 \mathrm{ft}$ [19]. Depending on the structure and type of the formation, the depth can vary. Therefore, for the method to be very effective, the formation should have thick pay zone of greater than 10 meters, oil saturation greater than $40 \%$ and porous sand greater than $30 \%$. As the geology is important for steam distribution, unconsolidated sand with low clay is favorable. Additionally, 10 API gravity and viscosity of oil between 1000 to $4000 \mathrm{cp}$ is considerable with permeability of at least $100 \mathrm{md}$. The three stages of CSI is demonstrated in the figure below.

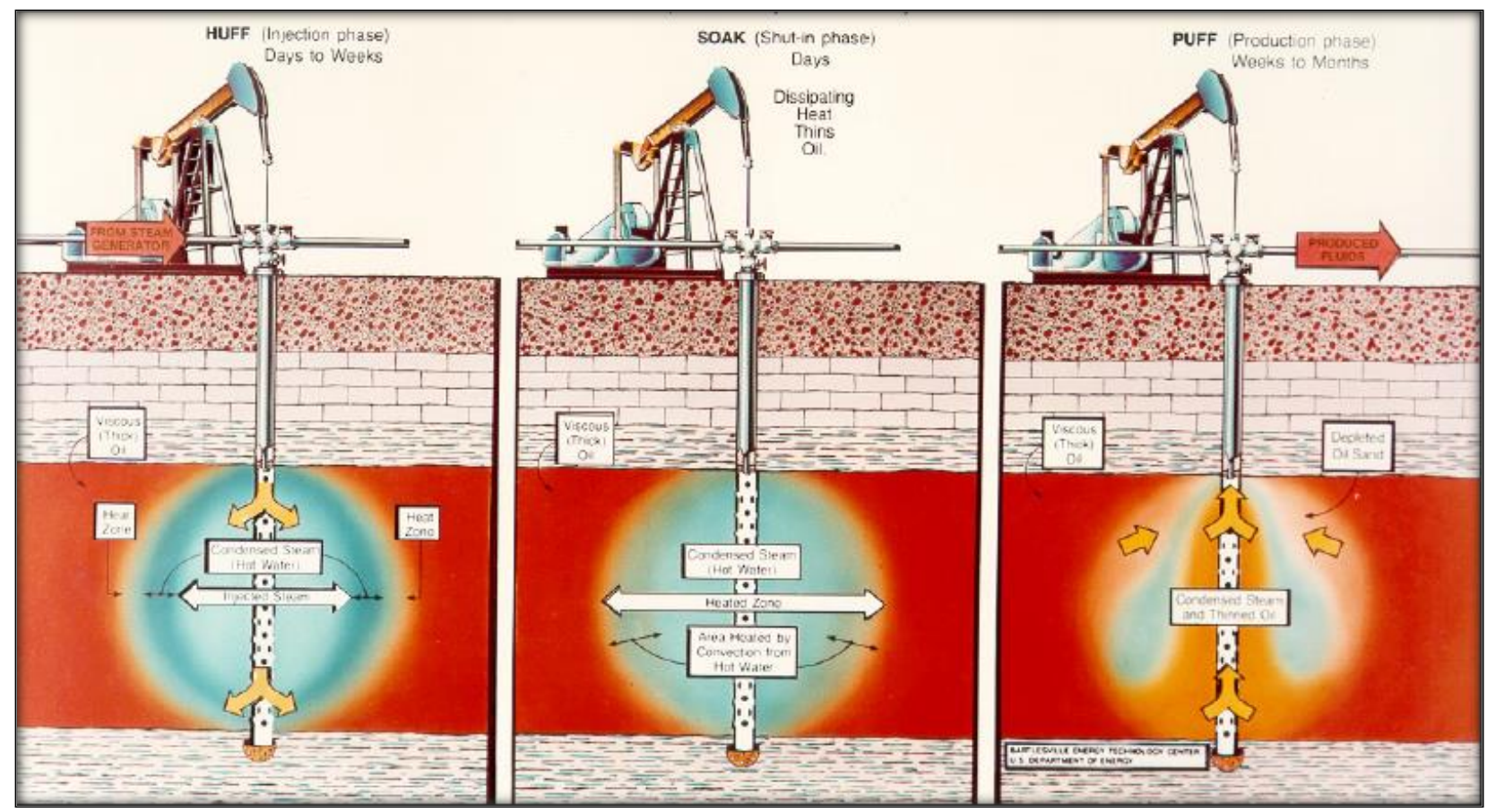

Figure 2-4 Different Process Steps in Cyclic Steam Simulation

The ultimate recovery from CSI is relatively low to total oil in the reservoir. However, the ultimate recovery from steam drive is higher. As steam flooding and CSI alone are not so effective, steam flooding may follow CSI as CSI recovers heavy oil around single well bore and steam flooding recovers oil between the wells. In some cases to help increase the initial production, steam flooding wells are produced for 1 or 2 cyclic steam simulation. This also leads to high operating cost and high steam capital. CSI followed by steam drive is a good combination for accelerating crude production and ultimate recovery [20]. By adjusting the artificial lift and injection of steam rates, the fluids from each well can be used to optimize the production. To identify which sub formation zone is producing gas, oil or water, downhole fluids flow measurements can be used. The cyclic steam simulation and steam flooding are mostly used 
on vertical wells. Recently, horizontal wells and vertical wells with multilateral branches have tried using these methods with advantages of reduced footprint while trapping large subsurface regions. In such cases, when heavy crude oil is present in the reservoir, steam drive is inefficient and steam injection rates are limited due to high resistance to flow between wells. Cyclic steam injection reduces the resistance near the wells and this improves the injection rate by reducing the resistance to flow between the wells during the steam drive. The heated zones can be connected when cyclic steam injection process is repeated to further reduce the flow resistance and improve the steam drive operability. Steam flooding, steam drive and CSI are all related to the cost of steam which is generated by natural gas. To improve the economics, the waste heat can be used for co-generation or electricity can be generated and sold. Alternative fuels such as coal, coke etc. can also be used to generate steam. This process can control the overuse of steam by redirecting the steam where heavy oil has not been produced and shutoff from zones that have been swept. The natural occurrence of the gravity overrides in every steam flooding process. The expansion of the steam occurs downward and the heated crude oil drains from the production well by gravity. In the further section it is described how the geometry of this is totally different from SAGD (steam assisted gravity drainage) however, the basics mechanism is same [19].

\subsubsection{Steam Flooding}

Steam flooding is a widely used advanced technology to enhance heavy oil reservoir and improves the performance of low permeability reservoir. It is a widely used technology for heavy oil reservoir as well as low permeability light oil reservoir [20]. The basic principle of this process is that high temperature steam is injected into the reservoir that heats up the formation and steam acts as driving force to push oil from the producing well. The lighter components in the crude is distilled due to the presence of the gas phase and carried with hydrocarbon compounds. At the condensation front, steam condenses the hydrocarbon compounds leading to the reduction in viscosity. The condensation of the steam makes the process efficient and increase the sweep efficiency. When compared to hot water drive, the recovery is significantly higher from steam [19]. 


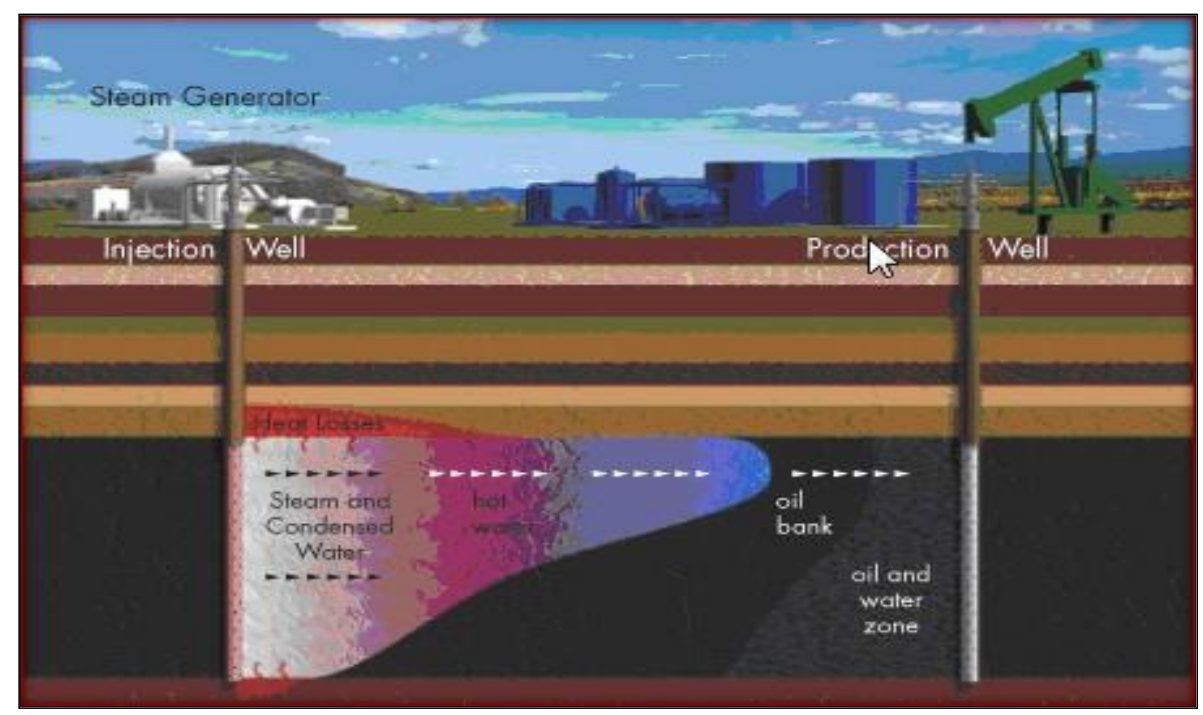

Figure 2-5 Steam Process After Initial Cycle [21]

In steam flooding, there is a separate injection and production well. This process is continuous as steam is injected from the injection well to form saturated steam zone around the well bore. There are two steps to this process-

1. Direct Steam Stimulation- Steam stimulation of production well.

2. Indirect Steam Stimulation- To increase the production from other wells, steam is injected to increase steam drive [19].

\subsubsection{Steam assisted gravity drainage}

There are other processes one of them namely Steam Assisted Gravity Drainage Technology by which heavy oil crude and bitumen is recovered. In this process, two horizontal wells are drilled into the oil reservoir few meters (approximately 5 meters) above the other and advanced steam simulation is performed. The high pressure steam is injected into the upper wellbore to heat the oil and further reduce its viscosity. This heat drains the oil into the lower wellbore from where it is pumped out [19]. 


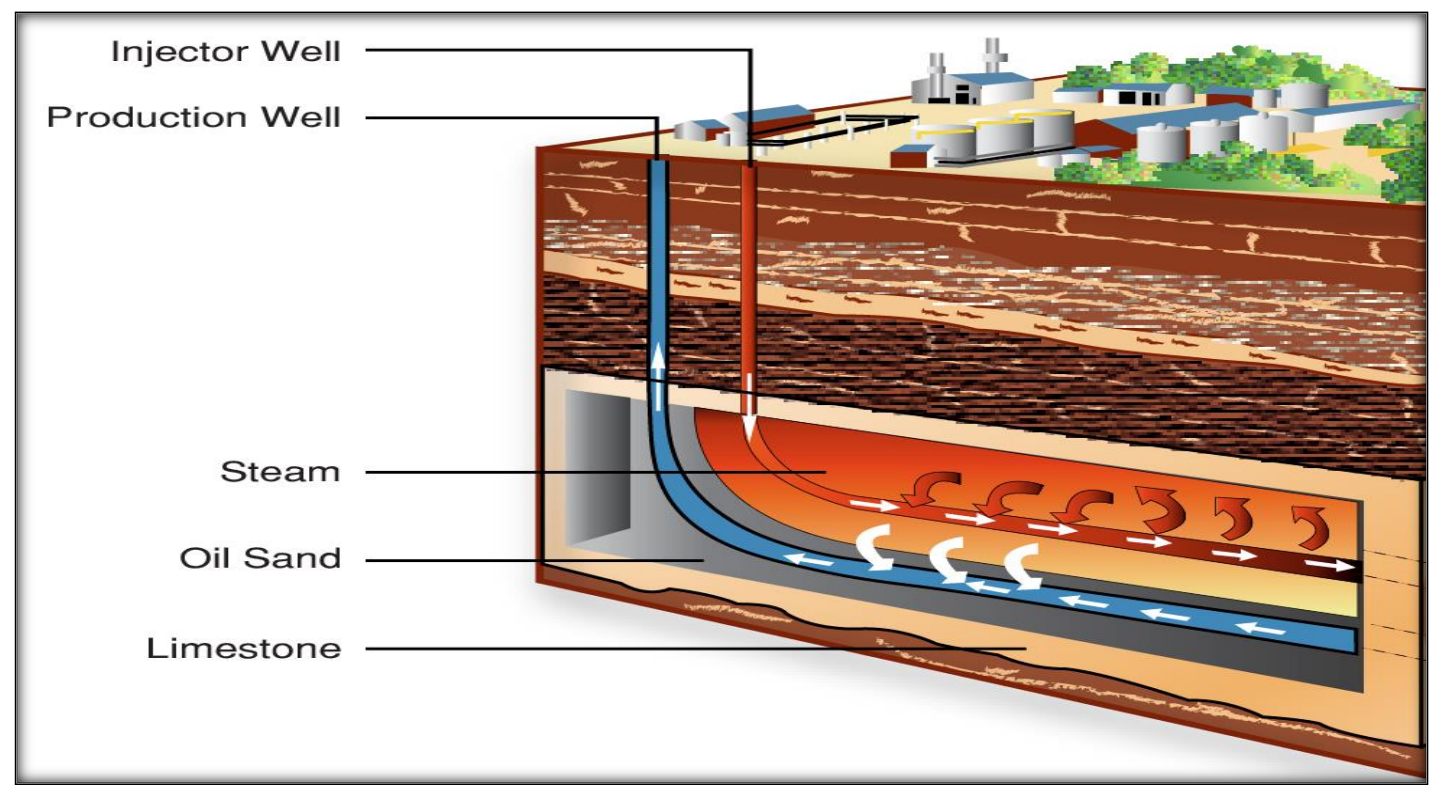

Figure 2-6 Cross Section of Steam Assisted Gravity Drainage [22]

The mixture of sand, water and bitumen is called oil sand [23]. As it is very viscous and cannot flow like conventional crude. It must be heated underground before it can be produced and processed. The Twenty percent of the oil sand reserves are close to the surface and can be mined to be extracted. However, $70 \%$ of the reserves are on an average of 1300 feet below the surface. So in order to extract these deep bitumen deposits, techniques such as SAGD must be used. The steam injection and oil production from the two horizontal wells happen continuously [24]. The top well injects steam, which further heats bitumen to be separated from sand and collects in the lower well with produced water. The mechanism of this process takes place in 3 steps namely, steam condenses at interface, condensate and oil flow to the bottom as a result of gravity, and chamber grows sideways and upwards due to the continuous injection of steam as showed in the figure below [25]. The bitumen and water produced from the wells is sent to the upgrading plant where bitumen is separated from the water. This water is recycled into the steam generator and injected back into the upper horizontal well [24]. 


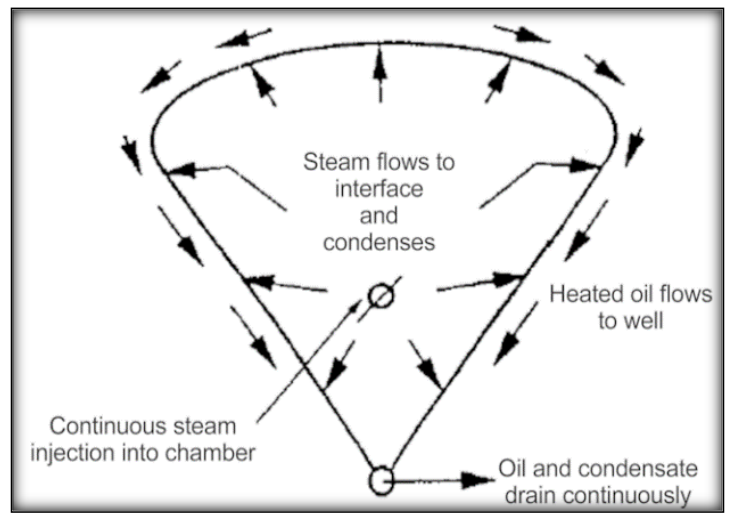

Figure 2-7 Conceptual diagram of the SAGD process [25]

The difference between water's saturation temperature at producer pressure and actual temperature where pressure is measured is called sub cool. Sub cool is higher and temperature is lower if the liquid level is above the producer. As reservoirs are heterogeneous, it becomes challenging to achieve sub cool throughout the length of the horizontal well. Therefore, when uneven steam chamber development is faced, small quantity of steam enters the producer. This allows the bitumen to remain hot in the entire wellbore thus keeping its viscosity low and this allows transferring heat to the colder parts of the well. Also, when operator deliberately circulates steam in the producer following a shut in period, this process is called partial SAGD. With high value of sub cool, the steam injection and production slightly reduces due to high viscosity and lower mobility of bitumen at low temperature. The high steam pressure cannot sustain the steam chambers and can result in its collapse. With continuous injection and production at reservoir pressure, instability problems are even out and production rate increases to 70 to $80 \%$ of OOIP. SAGD is twice as efficient as CSS process and results in fewer well damages by high pressure. Additionally, it is even more economical as recovery rate of oil is higher. The formation with thin shale barriers produces the recovery rate of 60 to $70 \%$ [26].

\subsection{Solar Generator for Thermal Enhanced Oil Recovery}

Solar Enhanced Oil Recovery uses concentrated solar Energy to convert light energy into heat energy which further heats the water and converts it into steam. This steam is further heated up to 400 degree Celsius with pressure of 100 bar and is injected into oil well to reduce viscosity of heavy oil and makes it easier to recover [27]

The system has two main components namely, reflector and receiver. The reflector is the mirror that captures and focus sunbeam onto the receiver and receiver contains water which is 
further heater to be converted into steam. The tracking system keeps the sunlight focused throughout the day on receiver. The solar power EOR systems also have thermal energy storage system that collects heat energy during the day and produce steam from water in the evening or during less sunny days [28]. On the other hand, hybrid systems using natural gas combined with solar powered steam generators supplement energy during low solar radiation period. With the help of solar EOR, steam is produced during morning hours when solar energy is available and gas fired steam is used during the night or less sunny days. With this process, large amount of natural gas consumption can be lowered without affecting the output of heavy oil.

\subsubsection{Types}

\subsubsection{Central Tower-}

Central tower also known as power tower technology uses heliostats, large tracking mirrors to focus concentrated sunlight onto the central tower receiver filled with demineralized water [29]. Sunlight can be concentrated upto 1,500 times onto water, which is used as the heat transfer fluid [30]. The reflected sun's energy heats up the water to produce high temperature and pressure steam. This steam passes through the heat exchanger into distribution heater and further to injection wells [31].

\subsubsection{Linear Concentrating System}

Linear concentrating system uses long $U$ shaped mirror to focus sunlight on the receiver tubes that run through the length of the mirror. The fluid flowing through the tubes is heated with the concentrated sunlight and is sent to heat exchanger into distribution heater to injection wells. There are two types of linear systems namely- parabolic trough systems and linear Fresnel reflector systems. In parabolic trough system, the receiver is positioned along the focal length of mirror and has a parabolic shape. The mirrors can focus 30 to 100 times the normal intensity of sun light achieving a temperature of up to 750 degree Fahrenheit. There are three major plants in the U.S. - Mojave Solar Project in California, Solana Generating Station in Arizona, and Genesis Solar Energy Project in California. Linear Fresnel reflector system uses Fresnel effect to concentrate 30 times normal intensity solar rays to be concentrated onto mirrors with large aperture and short focal length. The receiver is placed above several mirrors to allow greater mirror mobility for tracking the sun with increased efficiency and reduced material cost and requirement. Linear concentrating systems are built aligned to north-south orientation to collect maximum solar energy and enable the tracking of sun from east to west during the day [28]. 


\subsection{Natural Gas Generator for Thermal Enhanced Oil Recovery}

Natural gas steam generators are used in oil fields to generate saturated steam from injection fluid into the reservoir for enhanced oil recovery. For the conversion of water into steam, the generators are installed with steam drums. The steam drum has centrifugal drum that uses centrifugal and inertia forces with the heat from the exhaust gas to convert water into steam. The superheated section then further heats the steam to the desired temperature [32]. Typical efficiency of natural gas steam generator is between $80-85 \%$ however, can increase to $90 \%$ with special equipment design. Typical capacity of steam generators range from $10^{7}$ to $150 \times 10^{6}$ $\mathrm{Btu} / \mathrm{Hr}$. The corresponding rate of feedwater ranges from 650 to 10,000 BWPD (barrels of feedwater per day) recovering $80 \%$ quality steam. The size of the steam generator depends on the overall cost effectiveness [33].

\subsubsection{Types}

\subsubsection{Once through Steam Generators}

There are two types of gas steam generators namely Once through Steam Generators (OTSG) and Heat Recovery Steam Generators (HRSG). Once through Steam Generator (OTSG) is a special type of HRSG without boiler drums. OTSG are designed to have a continuous path for feedwater and does not have economizer, evaporator or superheater. As these generators are designed based on the heat load, they have high degree flexibility. With the absence of steam drum, there are fewer variables to control leading to quick change in the production of steam. In OTSG, hot exhaust gases can pass over the tubes with no water flowing inside with proper material selection. With this design, exhaust gas diverter system and bypass stack are eliminated [34]. The basic design of OTSG is shown in the figure below- 


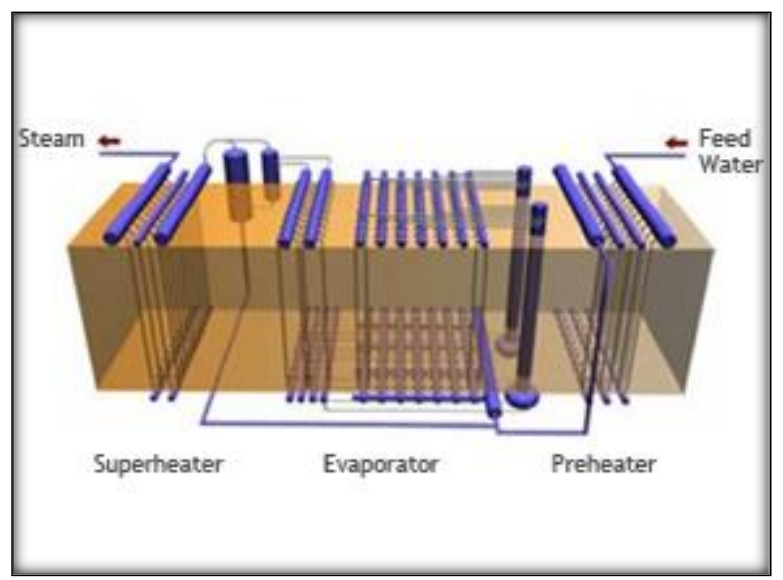

Figure 2-8 Once Through Steam Generators [35]

\subsubsection{Heat Recovery Steam Generators}

There are four main systems in Heat Recovery Steam Generators (HRSG) namely the preheater, evaporator, economizer and superheater. This generator can be categorized based on several variables such as the level of pressure or direction of exhaust gas and water. In horizontal HRSG, the exhaust gas flows horizontally over vertical tubes however, in vertical HRSG, exhaust gas flows vertically over horizontal tubes. The HRSG analyzed for this report has dual pressure system consisting of high and low pressure systems. There are steam generators that have single or triple pressure sections. Each section has steam drum that recirculates water and water-steam mixture to form saturated steam which is further converted into superheated steam. The figure below shows the design of HRSG [34]-

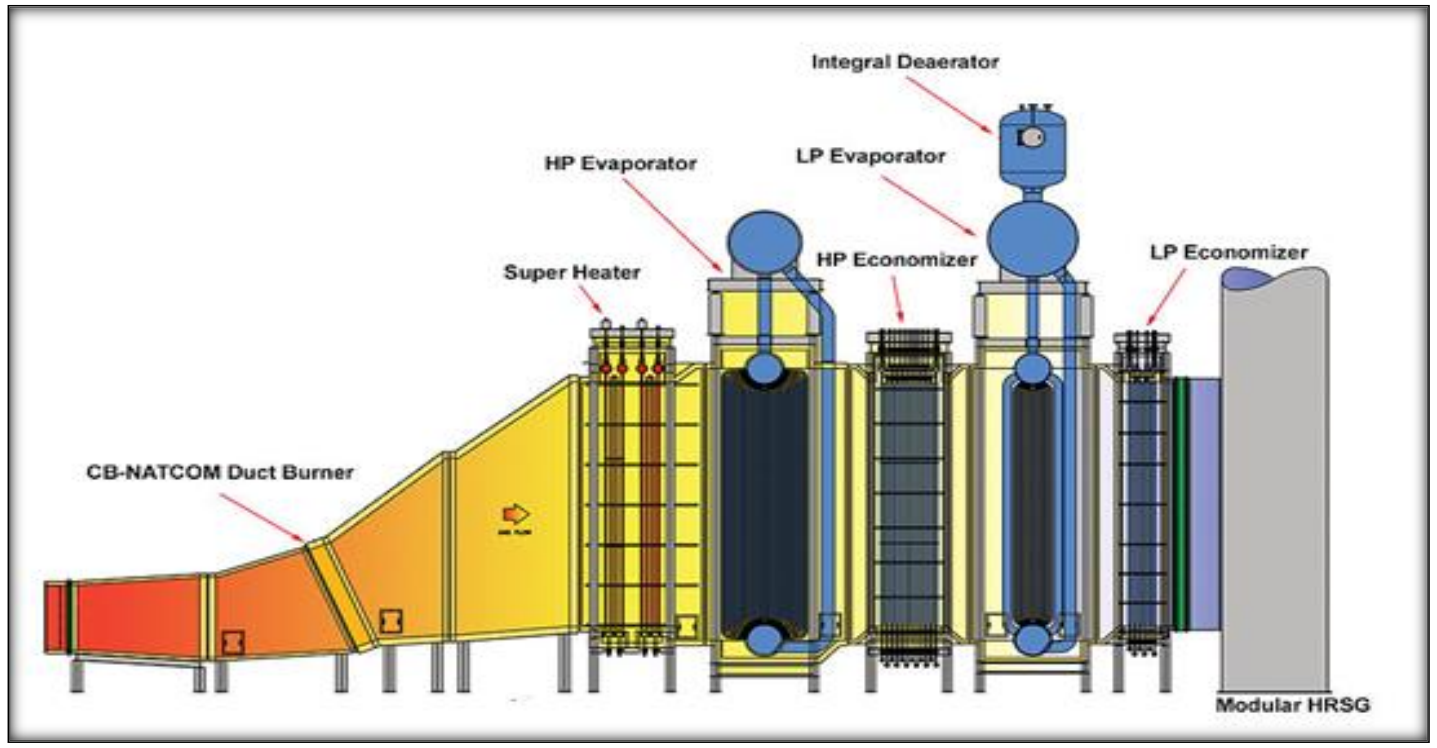

Figure 2-9 Cross Section of Heat Recovery Steam Generator [34] 


\subsection{Case Study}

\subsubsection{Aera Energy}

Aera Energy has many oil fields where TEOR (Thermal Enhanced Oil Recovery) is performed such as South Belridge, Coalinga, Cymric, Lost Hills, McKittrick, Midway-Sunset, and San Ardo [36]. Kern County is the largest producing county for Aera Energy and includes Belridge, Cymric, Kern River, McKittrick, Midway-Sunset, and Lost Hill fields. The onshore operations are performed at San Ardo and Coalinga [37]. Heavy oil is recovered form Tulare formation and the company produces 75,000 barrels of oil per day from here. The south of Belridge is the $6^{\text {th }}$ most and Lost Hill is the $9^{\text {th }}$ most productive fields in the United States [38]. Coalinga is located in the Fresno County and produces approximately 6,000 barrel of heavy oil per day [39]. Midway Sunset field is located in the southwest of Kern County and ranks top 10 in the production of oil in the U.S [40]. San Ardo is located in the Monterey County and produces an approximate of 10,200 barrels of heavy oil per day [41]. The location of fields are shown in the figure below-

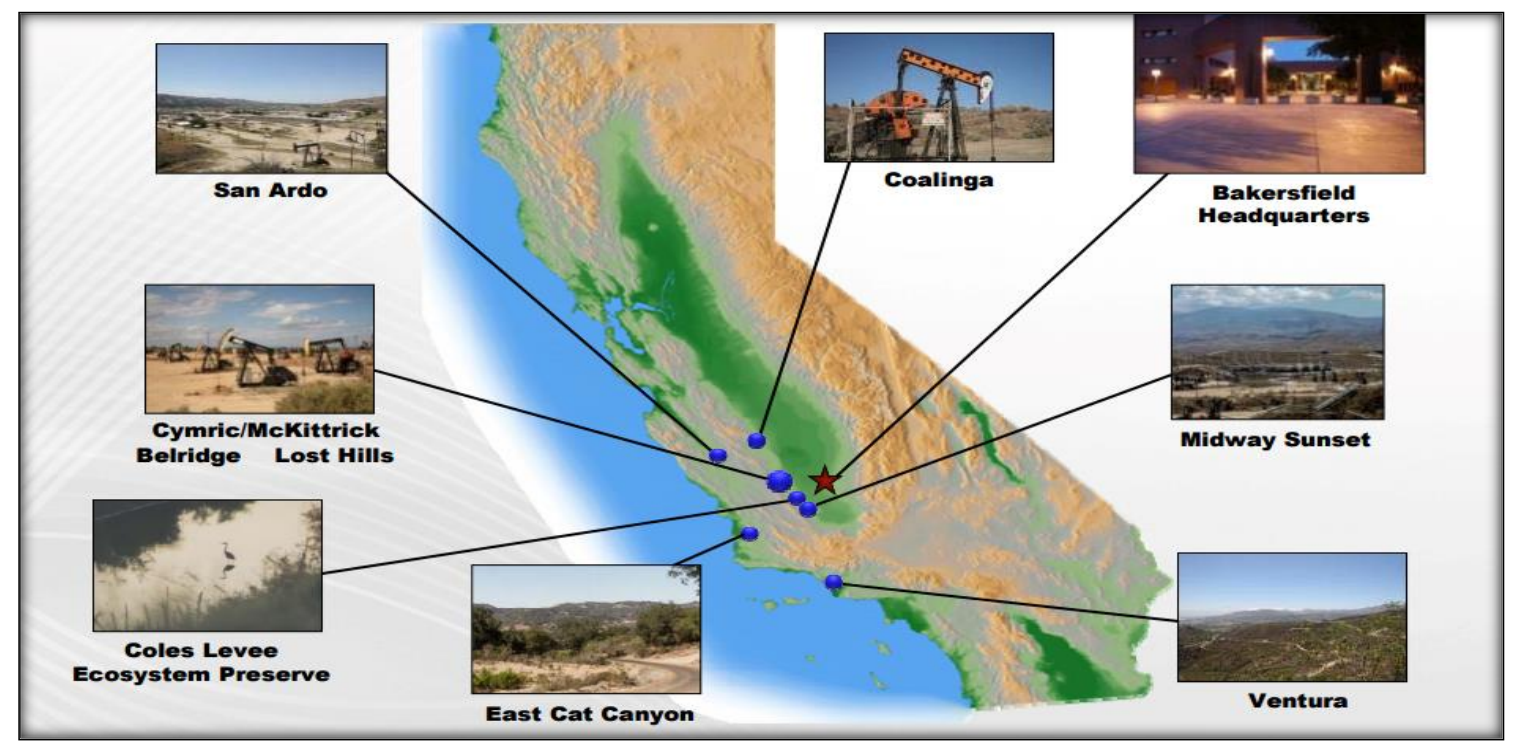

Figure 2-10 Different Areas of Operation by Aera Energy [42]

Additional information on the fields and EOR production is shown in the table below- 


\begin{tabular}{|c|c|c|c|c|c|c|}
\hline Field & Lease Operator & $\begin{array}{l}\text { Fuel } \\
\text { Type }\end{array}$ & $\begin{array}{l}\text { Maximum Power } \\
\text { Output (MW) }\end{array}$ & $\begin{array}{l}\text { Surplus } \\
\text { Power } \\
\text { Buyer }\end{array}$ & $\begin{array}{c}\text { Approx. Plant } \\
\text { Cost } \\
\text { (\$ millions) } \\
\end{array}$ & Fuel Requirements \\
\hline Belridge S. & Aera & Gas & 9.6 & None & 12.0 & $6.0 \mathrm{MMcf} / \mathrm{d}$ \\
\hline Belridge S. & Aera & Gas & 65.0 & PGE & 53.0 & 15.6 MMcf/d \\
\hline Kern River & Aera & Gas & 28.0 & PGE & 33.1 & $7.3 \mathrm{MMcf} / \mathrm{d}$ \\
\hline Kern River & Aera & Gas & 46.0 & PGE & 57.0 & $9.5 \mathrm{MMcf} / \mathrm{d}$ \\
\hline Midway-Sunset & Aera & Gas & 4.0 & PGE & 6.0 & 1.2 $\mathrm{MMc} / \mathrm{d}$ \\
\hline San Ardo & Aera & Gas & 6.2 & None & 8.2 & $3.8 \mathrm{MMc} / \mathrm{d}$ \\
\hline
\end{tabular}

Table 2-1 EOR production at Different AREA Energy Fields [43]

The arrows marked on the table below represent the additional fields of the Aera Energy.

\begin{tabular}{|c|c|c|c|c|c|c|c|c|c|c|}
\hline Operator & Fieid & State & County & $\begin{array}{c}\text { Date } \\
\text { Begun } \\
\end{array}$ & $\begin{array}{l}\text { Prod } \\
\text { Wells } \\
\end{array}$ & $\begin{array}{l}\text { Inject } \\
\text { Wells }\end{array}$ & $\begin{array}{c}\text { Depth } \\
\mathrm{Ft}\end{array}$ & $\begin{array}{c}\text { Total Prod } \\
\text { BOPD }\end{array}$ & $\begin{array}{c}\text { EOR Prod } \\
\text { BOPD } \\
\end{array}$ & $\begin{array}{c}\text { Estim } \\
\text { Power (hp) }\end{array}$ \\
\hline AERA & Bekidge & CA & Kern & $\operatorname{Jan}-61$ & 2,900 & 975 & $400-1,400$ & 37,000 & 37,000 & 27,750 \\
\hline AERA & $\rightarrow$ Cat Canyon & $C A$ & Santa Barbara & Mar-85 & & & $2,500-4,500$ & & & \\
\hline AERA & Coalinga & CA & Fresno & $\tan -80$ & 190 & 22 & $825 \cdot 1,650$ & 3.580 & 3.580 & 2,685 \\
\hline AERA & Coalinga & CA & Fresno & Nov-87 & 172 & 48 & $650-1000$ & 5,850 & 5,850 & 4,388 \\
\hline AERA & Oymric & $C A$ & Kern & Dec-86 & 100 & 46 & 1,000 & 5.600 & 5,600 & 4,200 \\
\hline AERA & Kem River & CA & Kern & $\operatorname{Jan}-70$ & 840 & 270 & $150-1,500$ & 10,800 & 10,800 & 8,100 \\
\hline AERA & Lost Hills & $\mathrm{CA}$ & Kern & Jun-90 & 100 & 36 & 350 & 4,070 & 4,070 & 3,053 \\
\hline AERA & Lost Hils & $\mathrm{CA}$ & Kern & Jun-90 & 125 & 37 & 200 & 4,500 & 4,500 & 3,375 \\
\hline AERA & Mckitrick & CA & Kern & Mar-88 & 145 & 115 & 600 & 4,500 & 4,500 & 3,375 \\
\hline AERA & Midway-Sunset & $\mathrm{CA}$ & Kern & Oct-70 & 381 & 32 & 950 & 12,000 & 12,000 & 9,000 \\
\hline AERA & Midway-Sunset & $\mathrm{CA}$ & Kern & $\operatorname{Jan}-79$ & 66 & 0 & 900 & 800 & 800 & 600 \\
\hline AERA & Midway-Sunset & CA & Kern & $\operatorname{Jan}-89$ & 78 & 8 & 800 & 1,600 & 1,500 & 1,125 \\
\hline AERA & Midway-Sunset & CA & Kern & $\operatorname{Jan}-83$ & 205 & 25 & 1,080 & 4,300 & 4,300 & 3,225 \\
\hline AERA & Midway-Sunset & CA & Kern & $\operatorname{Jan}-71$ & 650 & 34 & $500-1,400$ & 6,600 & 6,600 & 4,850 \\
\hline AERA & Midway-Sunset & CA & Kern & Jan-80 & 145 & 8 & 1,300 & 2,200 & 2,200 & 1,650 \\
\hline AERA & Mount Poso & CA & Kern & $\operatorname{Jan}-71$ & 75 & 16 & $1,500-1,800$ & 3,100 & 3,100 & 2,325 \\
\hline AERA & North Midway-Sunset & CA & Kern & Nov-67 & 376 & 21 & 1,000 & 10,750 & 10,750 & 8,063 \\
\hline AERA & San Ardo & CA & Monterey & Jun-68 & 100 & 28 & 2,300 & 1.930 & 1,930 & 1,448 \\
\hline AERA & San Ardo & CA & Monterey & Mar-80 & 42 & 14 & 2,100 & 7,350 & 7,350 & 5,513 \\
\hline AERA & South Belridge & $\mathrm{CA}$ & Kern & Jan-69 & 510 & 263 & 1,000 & 43,200 & 43,200 & 32,400 \\
\hline AERA & South Belridge & CA & Kern & $\operatorname{Jan}-65$ & 50 & & 1,000 & 460 & 460 & 345 \\
\hline AERA & Yorba Linda & $\mathrm{CA}$ & Orange & $\operatorname{Jan}-71$ & 203 & 11 & $500-1,000$ & 1,000 & 750 & 563 \\
\hline ARCO & Kern River & $C A$ & Kern & $\operatorname{Jan}-70$ & 88 & 11 & 600 & 370 & 370 & 278 \\
\hline ARCO & Kem River & CA & Kern & $\operatorname{Jan}-70$ & 87 & 28 & 1,200 & 1,000 & 1,000 & 750 \\
\hline ARCO & Kem River & CA & Kern & Sep-72 & 25 & 11 & 900 & 300 & 300 & 225 \\
\hline ARCO & Kem River & $C A$ & Kern & $\operatorname{Jan}-72$ & 80 & 39 & 800 & 800 & 800 & 600 \\
\hline ARCO & Midway-Sunset & $\mathrm{CA}$ & Kern & $\operatorname{Jan}-72$ & 63 & 7 & 1,200 & 1,050 & 1,050 & 788 \\
\hline ARCO & Midway-Sunset & CA & Kem & May-05 & 137 & 13 & 1,500 & 3,500 & 3,500 & 2,625 \\
\hline ARCO & Midway-Sunset & $\mathrm{CA}$ & Kern & $\operatorname{Jan}-83$ & 109 & 42 & 1,500 & 2,500 & 2,500 & 1,875 \\
\hline ARCO & Midway-Sunset & CA & Kern & $\operatorname{Jan}-81$ & 94 & 13 & 1,200 & 1,250 & 1,250 & 938 \\
\hline ARCO & Midway-Sunset & $\mathrm{CA}$ & Ken & Aug -72 & 130 & 5 & 1,000 & 900 & 900 & 675 \\
\hline ARCO & Midway-Sunset & CA & Kern & $\operatorname{Jan}-84$ & 7 & 0 & 1,300 & 120 & 120 & 90 \\
\hline ARCO & Midway-Sunset & CA & Kern & Jan-69 & 98 & 17 & 1,100 & 2,700 & 2,700 & 2,025 \\
\hline ARCO & Midway-Sunset & $\mathrm{CA}$ & Kern & $\operatorname{Jan}-89$ & 127 & 4 & 1500 & 1.750 & 1.750 & 1,313 \\
\hline
\end{tabular}

Table 2-2 Additional Fields of EOR Operation by AERA Energy [43]

One of the parent companies, Shell holds 52\% of EOR holding in AERA Energy and produces 100,000 barrels of oil through steam flooding in California [44]. The 96.5\% of EOR operations worldwide are performed by steam generators out of which $65 \%$ occur in north of 
America and out of which 94\% occur in California's San Joaquin Valley. The oil recovered in San Joaquin Valley is 303,000 barrels per day using 768 OTSGs each averaging about 60 MMBTU per hour [45]. With the engagement of AERA and ClearSign in the installing of OTSG in Bakersfield, high energy efficiency was achieved at high firing rate and reduced NOx emission to less than 5 parts per million (PPM) [46]. For the production of steam, Aera is selfsufficient with the water supply. $99 \%$ of the water used in the EOR is recycled with the use of less than $1 \%$ of fresh water. Freshwater is used for dust suppression, equipment and process cooling, drilling, hydraulic fracturing, and domestic use [42]. Some of the specifications of EOR production in Aera Energy fields are shown in the figure below-

\begin{tabular}{|c|c|c|c|c|c|c|c|}
\hline \multicolumn{8}{|c|}{$\begin{array}{l}\text { Midway Sunset } \\
\text { Aera }\end{array}$} \\
\hline Operation & Equipment & $\begin{array}{c}\text { HP Capacity } \\
\text { (hp) }\end{array}$ & Units & $\begin{array}{c}\text { Cum HP } \\
\text { Capacity } \\
\text { (hp) }\end{array}$ & $\begin{array}{c}\text { Adj. HP } \\
\text { Capacity } \\
\text { (hp) }\end{array}$ & \begin{tabular}{|c|} 
Adj. MW \\
Capacity \\
(mw)
\end{tabular} & $\begin{array}{l}\text { Adj. MW } \\
\text { Usage } \\
(\mathrm{mwh} / \mathrm{yr})^{1}\end{array}$ \\
\hline Fluid Lift & Rod Pump & 30 & 1,525 & 45,750 & 45,750 & 34.13 & 269,077 \\
\hline Water Injection & Central Facility & 2,000 & 20 & 40,000 & 40,000 & 29.84 & 235,259 \\
\hline (Disposal) & \begin{tabular}{|l|} 
Individual \\
Injection Wells
\end{tabular} & 120 & 300 & 36,000 & 36,000 & 26.86 & 211,733 \\
\hline \multirow{2}{*}{\multicolumn{8}{|c|}{$\begin{array}{l}\text { Total: } \\
\text { Co-Generation }\end{array}$}} \\
\hline & & & & & & & \\
\hline Operation & Units & $\begin{array}{c}\text { Unit Fuel } \\
\text { Requirment } \\
\text { (mmcfd) }\end{array}$ & $\begin{array}{c}\text { Total } \\
\text { Fuel } \\
\text { (mmcfd) }\end{array}$ & $\begin{array}{c}\text { Unit Steam } \\
\text { Generation } \\
\text { (lbs/hr) }\end{array}$ & $\begin{array}{c}\text { Total Steam } \\
\text { Generation } \\
\text { (lbs/hour) }\end{array}$ & \begin{tabular}{|c|} 
Unit \\
Capacity \\
(MW)
\end{tabular} & $\begin{array}{c}\text { Total } \\
\text { Capacity } \\
\text { (MW) }\end{array}$ \\
\hline $\begin{array}{l}\text { Electricity/Steam } \\
\text { Generation }\end{array}$ & 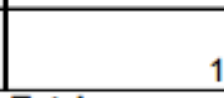 & 4.8 & 4.8 & 25,000 & 25,000 & 4 & \\
\hline & Total: & & 4.8 & & 25,000 & & 4 \\
\hline
\end{tabular}

Assumes $24 \mathrm{hr} /$ day, 328 days/year

Table 2-3 Different Operations at Midway Sunset, AERA Energy

This field produces 27,500 BOPD from 107 steam injection wells and 1525 production well. For the generation of electricity and steam, natural gas is used. The $4^{\text {th }}$ highest expense of the operation is electricity and is purchased from local utility at $\$ 0.043$ to $\$ 0.18 \mathrm{KWH}$ [43]. 


\begin{tabular}{|c|c|c|c|c|c|c|c|}
\hline \multicolumn{8}{|c|}{$\begin{array}{l}\text { South Belliridge } \\
\text { Aera }\end{array}$} \\
\hline Operation & Equipment & $\begin{array}{c}\text { HP Capacity } \\
\text { (hp) }\end{array}$ & Units & $\begin{array}{c}\text { Cum HP } \\
\text { Capacity } \\
\text { (hp) }\end{array}$ & $\begin{array}{c}\text { Adj. HP } \\
\text { Capacity } \\
\text { (hp) }\end{array}$ & \begin{tabular}{|c|} 
Adj. MW \\
Capacity \\
(mw)
\end{tabular} & $\begin{array}{c}\text { Adj. MW } \\
\text { Usage } \\
\text { (mwh/vr) }\end{array}$ \\
\hline Fluid Lift & Rod Pump & 30 & 560 & 16,800 & 16,800 & 12.53 & 98,809 \\
\hline $\begin{array}{l}\text { Water Injection } \\
\text { (Disposal) }\end{array}$ & Central Facility & 2.000 & 5 & 10,000 & 10,000 & 7.46 & 58,815 \\
\hline & & & Total: & 26,800 & 26,800 & 20 & 157,623 \\
\hline \multicolumn{8}{|c|}{ Co-Generation } \\
\hline Operation & Units & $\begin{array}{c}\text { Unit Fuel } \\
\text { Requirment } \\
\text { (mmcfd) }\end{array}$ & $\begin{array}{c}\text { Total } \\
\text { Fuel } \\
\text { (mmcfd) }\end{array}$ & $\begin{array}{c}\text { Unit Steam } \\
\text { Generation } \\
\text { (lbs/hr) }\end{array}$ & $\begin{array}{l}\text { Total Steam } \\
\text { Generation } \\
\text { (Ibs/hour) }\end{array}$ & \begin{tabular}{|c|} 
Unit \\
Capacity \\
(MW)
\end{tabular} & $\begin{array}{c}\text { Total } \\
\text { Capacity } \\
\text { (MW) }\end{array}$ \\
\hline \multirow{3}{*}{$\begin{array}{l}\text { Electricity/Steam } \\
\text { Generation } \\
\end{array}$} & 1 & 63 & 63 & 300,000 & 300.000 & 65 & 65 \\
\hline & 1 & 6 & 6 & 175,000 & 175,000 & 9.6 & 10 \\
\hline & Total: & & 69 & & 475,000 & & 75 \\
\hline
\end{tabular}

Assumes $24 \mathrm{hr} /$ day, 328 days/year

Table 2-4 Different Operations at South Bellridge, AERA Energy

For the above field, co-generated electricity is used for water disposal and fluid lift to generate useful heat and electricity at the same time. The steam generated and electricity produced on site is sufficient to carry out Aera's EOR process. As very little associated gas is produced from the field, the standby electricity is purchased from PG\&E for $\$ 0.20 / \mathrm{kWh}$. The production of EOR depends directly on fluid lift and if it shuts down, production stops immediately. This operation is carried out at later stages when the artificial lift is used for the production to maintain reservoir pressure against pressure drop due to depletion [43]. The information of power generation and additional co-generation in major fields of california is summarized below. 


\begin{tabular}{|l|c|c|c|c|c|c|}
\hline \multicolumn{1}{|c|}{ Field } & Projects & $\begin{array}{c}\text { Power } \\
\text { Capacity } \\
\text { (MW) }\end{array}$ & $\begin{array}{c}\text { Natural Gas } \\
\text { Usage } \\
\text { (MMcfd) }\end{array}$ & $\begin{array}{c}\text { Cogenerated } \\
\text { Steam } \\
\text { Injected } \\
\text { (MBS/D) }\end{array}$ & $\begin{array}{c}\text { Total Steam } \\
\text { Injected } \\
\text { (MBS/D) }\end{array}$ & $\begin{array}{c}\text { Percent } \\
\text { Cogen/ } \\
\text { Total }\end{array}$ \\
\hline Kern River & 10 & 812 & 220 & 371 & 371 & $100 \%$ \\
\hline Midway-Sunset & 10 & 415 & 121 & 281 & 478 & $59 \%$ \\
\hline Kern Front & 4 & 189 & 44 & 25 & 25 & $100 \%$ \\
\hline Placerita & 2 & 142 & 49 & 20 & 20 & $100 \%$ \\
\hline San Ardo & 3 & 82 & 24 & 53 & 53 & $100 \%$ \\
\hline South Belridge & 2 & 75 & 22 & 60 & 291 & $21 \%$ \\
\hline Coalinga & 5 & 59 & 22 & 65 & 87 & $75 \%$ \\
\hline Mt. Poso & 1 & 50 & (coal-fired) & 3 & 11 & $29 \%$ \\
\hline Cymric & 4 & 27 & 33 & 34 & 76 & $44 \%$ \\
\hline Lost Hills & 1 & 10 & 4 & 8 & 37 & $22 \%$ \\
\hline Total (10 Fields) & $\mathbf{4 2}$ & $\mathbf{1 , 8 6 1}$ & $\mathbf{5 3 9}$ & $\mathbf{9 2 0}$ & $\mathbf{1 , 4 4 9}$ & $\mathbf{6 3 \%}$ \\
\hline Total California TEOR & $\mathbf{5 1}$ & $\mathbf{2 , 0 7 1}$ & $\mathbf{6 2 5}$ & $\mathbf{9 3 4}$ & $\mathbf{1 , 5 2 1}$ & $\mathbf{6 1 \%}$ \\
\hline
\end{tabular}

Table 2-5 Summary of Cogeneration in California Fields [43]

\subsubsection{Chevron}

Chevron is an American multination energy company that has various thermal EOR fields with leading capabilities such as reservoir simulation and laboratory testing in gas EOR clear[46]. Thermal EOR of Chevron operates in Kern, Fresno and Monterey County of California and Coat of Sumatra of Riau Province [43]. Chevrons Monterey County is the $4^{\text {th }}$ largest producer of oil in California and oil field San Ardo includes various TEOR (Thermal Enhanced Oil Recovery) methods such as Conventional, Cyclic Steam Injection, Steam Flooding and Water Flooding. The field produces up to 180,000 barrels of water per day and the used water is recycled by reverse osmosis process and injected into wastewater disposal well. Reverse osmosis is used to remove toxic and volatile organic compounds such as radioactive substance, heavy metals, and hydrocarbons. Chevron now processes up to 66,700 barrels of wastewater in San Ardo facility and recovers 50,000 barrels of treated water. The treated water is released into 
ponds under San Ardo field. The table below summarizes total production, EOR and other important details from each of the fields in chevron USA [47].

\begin{tabular}{|c|c|c|c|c|c|c|c|c|c|c|c|}
\hline \multirow{2}{*}{$\begin{array}{l}\text { Operator } \\
\text { Chevron }\end{array}$} & Field & \multicolumn{2}{|c|}{ State and County } & \multirow{2}{*}{\begin{tabular}{c|} 
Date \\
Oct-89
\end{tabular}} & \multirow{2}{*}{\begin{tabular}{r|} 
Prod wad \\
31
\end{tabular}} & \multirow{3}{*}{$\begin{array}{r}\text { Inj Well } \\
19 \\
47\end{array}$} & \multirow{2}{*}{\begin{tabular}{r|} 
Depth Ft \\
1,200
\end{tabular}} & \multicolumn{2}{|c|}{ Total Prod and EOR, Bd } & \multirow{2}{*}{$\begin{array}{l}\text { Power, hp } \\
1.096\end{array}$} & \multirow{2}{*}{ Suce. } \\
\hline & Cymric 26W & $\mathrm{CA}$ & Kern & & & & & 1.461 & 1.461 & & \\
\hline Chevron & Cymric $35 / 36 \mathrm{~W}$ & CA & Kern & May-75 & 130 & & 1,200 & 6.518 & 6,518 & 4.889 & Suce. \\
\hline Chevron & Cymric 52 & CA & Kern & Feb-91 & 14 & 4 & 1,200 & 591 & 591 & 443 & Suce. \\
\hline Chevron & Cymric $6 Z$ & CA & Kern & Feb-86 & 31 & 19 & 1,200 & 900 & 900 & 675 & Suce. \\
\hline Chevron & Cymric 72 & CA & Kern & May-91 & 30 & 30 & 600 & 70 & 70 & 53 & Suce. \\
\hline Chevron & Kern River-ANO & CA & Kern & May-74 & 177 & 82 & 1,000 & 3.643 & 3,643 & 2.732 & Suce. \\
\hline Chevron & Kem River KCL 39 & CA & Kern & Oct-75 & 67 & 42 & 1,400 & 379 & 379 & 284 & Suce. \\
\hline Chevion & Kern River MC1 & CA & Kern & Apr-76 & 120 & 76 & 960 & 2,072 & 2.072 & 1,554 & Suce. \\
\hline Chevron & Kern River MCII & CA & Kern & Apr-71 & 129 & 30 & 960 & 2.274 & 2.274 & 1,706 & Suce. \\
\hline Chevron & Kern River Sec. 3 & CA & Kern & Sep-68 & 345 & 155 & 775 & 8,340 & 8.340 & 6.255 & Suce. \\
\hline Chevron & Kern River Sec. 4 & CA & Kern & Jun-78 & 200 & 64 & 850 & 3,778 & 3,778 & 2.834 & Suce. \\
\hline Chevron & Kern River Sec.9 HHF & CA & Kern & Jan-92 & 8 & & 800 & 158 & 158 & 119 & Suce. \\
\hline Chevron & Midway-Sunset Sec. 15A & CA & Kern & May-78 & 36 & 5 & 1,400 & 1,600 & 1,600 & 1.200 & Suce. \\
\hline Chevron & Midway-Sunset Sec. $26 \mathrm{C}$ & CA & Kern & Nov-75 & 243 & 81 & 1,300 & 7,381 & 7,381 & 5,536 & Suce. \\
\hline Chevron & Midway-Sunset Sec. 2F & CA & Kern & Oct-83 & 44 & 10 & 1,800 & 2.251 & 2.251 & 1.688 & Suce. \\
\hline Chevron & West Coalinga 12-D & CA & Fresno & Feb-82 & 89 & 31 & 1,600 & 617 & 617 & 463 & Suce. \\
\hline Chevron & West Coalinga 13-D & CA & Fresno & May-73 & 182 & 104 & 1.200 & 2,465 & 2.465 & 1.849 & Suce. \\
\hline Chevron & West Coalinga 25-D & CA & Kern & May-80 & 131 & 95 & 2,500 & 5,441 & 5,441 & 4,081 & Suce. \\
\hline Chevron & West Coalinga 31AV362 & CA & Fresno & Mar-89 & 70 & 21] & 1.700 & 1.382 & 1.382 & 1.037 & Suce. \\
\hline Chevron & West Coalinga $6 C$ & $\mathrm{CA}$ & Fresno & $3 u 1-84$ & 131 & 18 & 1,500 & 689 & 689 & 517 & Suce. \\
\hline
\end{tabular}

Table 2-6 Thermal EOR Projects for Chevron in California [43]

Kern County is the $5^{\text {th }}$ largest producer in the U.S. With production continuing for 100 years, Chevron still continues to extract oil with the EOR technology. $70 \%$ of the chevron production in Kern County is with steam flooding. The recovery factor in kern valley is $60 \%$ compared to a global recovery of $32-35 \%$. The recovery factor is percentage of original oil in place that is recovered. In primary recovery, the oil recovered from Kern is only $5-10 \%$ however, with hot water injection it raises to $15-25 \%$. Furthermore with steam flooding the recovery can be achieved up to $80 \%$ [48]. Additional information on the fields and EOR production is shown in the table below-

\begin{tabular}{|l|l|l|c|c|c|c|}
\hline \multicolumn{1}{|c|}{ Field } & Lease Operator & $\begin{array}{c}\text { Fuel } \\
\text { Type }\end{array}$ & $\begin{array}{c}\text { Maximum Power } \\
\text { Output (MW) }\end{array}$ & $\begin{array}{c}\text { Surplus } \\
\text { Power } \\
\text { Buyer }\end{array}$ & $\begin{array}{c}\text { Approx. Plant } \\
\text { Cost } \\
\text { (\$ millions) }\end{array}$ & Fuel Requirements \\
\hline Coalinga & Chevron & Gas & 5.8 & PGE & 6.6 & $2.8 \mathrm{MMcf/d}$ \\
\hline Coalinga & Chevron & Gas & 5.8 & PGE & 5.5 & $2.8 \mathrm{MMcf/d}$ \\
\hline Coalinga & Chevron & Gas & 5.8 & PGE & 6.0 & $2.8 \mathrm{MMcf/d}$ \\
\hline Cymric & Chevron & Gas & 10.8 & PGE & 10.0 & $4.8 \mathrm{MMcf/d}$ \\
\hline Cymric & Chevron & Gas & 6.0 & PGE & 5.5 & $2.1 \mathrm{MMcf/d}$ \\
\hline Cymric & Chevron & Gas & 6.0 & PGE & 5.0 & $2.7 \mathrm{MMcf} / \mathrm{d}$ \\
\hline Kern River & Chevron & Gas & 42.0 & PGE & 32.5 & $11.8 \mathrm{MMcf/d}$ \\
\hline Midway-Sunset & Chevron & Gas & 12.5 & PGE & 10.0 & $7.2 \mathrm{MMcf/d}$ \\
\hline
\end{tabular}

Table 2-7 Cogeneration Facility for Chevron in California [43]

As steam flooding is very effective, it comes with a price of transporting natural gas and co-generation plants for the generation of steam and electrical power. The total energy consumed by co-generation plants is 62 million BTU which is equivalent to energy generated from 11 barrels of oil. This energy is used to generate 1,321 MW of power out of which Kern project 
consumes $550 \mathrm{MW}$ and rest is sold to power grid or used as a standby capacity. The reservoirs in Kern uses $180 \mathrm{kbpd}$ of steam for the injection and additional cold water seeps through the surrounding rock that comes up into the pumps as oil strained water. This results in the production of $75 \mathrm{kbpd}$ of oil, and $780 \mathrm{kbpd}$ of water. The average oil production from Chevron Kern County is 8 bpd and median production is 6 bpd [48]. Chevron partnership with Indonesia goes back to 88 years and it accounts to $40 \%$ of nation's crude oil from Sumatra [49]. It uses steam flooding at its field North Duri Development Area 13 located in Sumatra, Indonesia and produces 185,000 barrels per day. The field extends to an area of $324 \mathrm{sq}$. km and is considered largest steam development in the world. In 2015, 77 percent of the field was deployed with steam injection with majority of Chevron Pacific Indonesia production coming from Duri field. The NDD Area has 539 new wells including 145 steam injection and 36 temperature observation wells. This is expected to increase 17,000 barrels of production per day [50].

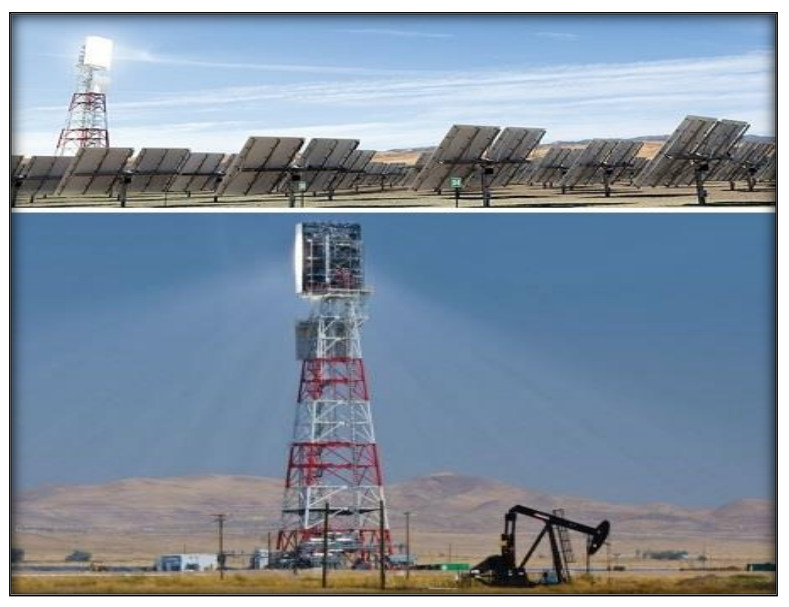

Table 2-8 Chevron Solar EOR in California [51]

According to the recent report by SBI, this has added an additional estimate of 241.7 barrels of oil increasing the recovery to 70-90\% [52]. The project extends to an area of 65 to 35 acre and consists of 3,822 mirror system (heliostats) of 10 by 7 foot on a steel pool of 6 foot. There are 7,644 mirrors in total focusing light on 327 foot of solar tower. The receiver on the solar tower captures solar rays and the heat produces steam for EOR. The steam generated is about the same as produced by one gas-fired steam generator [53].

\subsubsection{Berry Petroleum}

Berry Petroleum Company is an energy company primarily based out of California and is involved in production, development, acquisition, exploitation and exploration of crude oil and 
natural gas since 1985. The world's first commercial Solar Enhanced Oil Recovery (EOR) unit was setup by Glasspoint inc at Berry Petroleum's $21 \mathrm{Z}$ lease in Kern County, California. The system adopts sun's concentrated sunlight to produce 1 million Btu per hour of solar heat thereby reducing the gas consumption from oilfield [54].

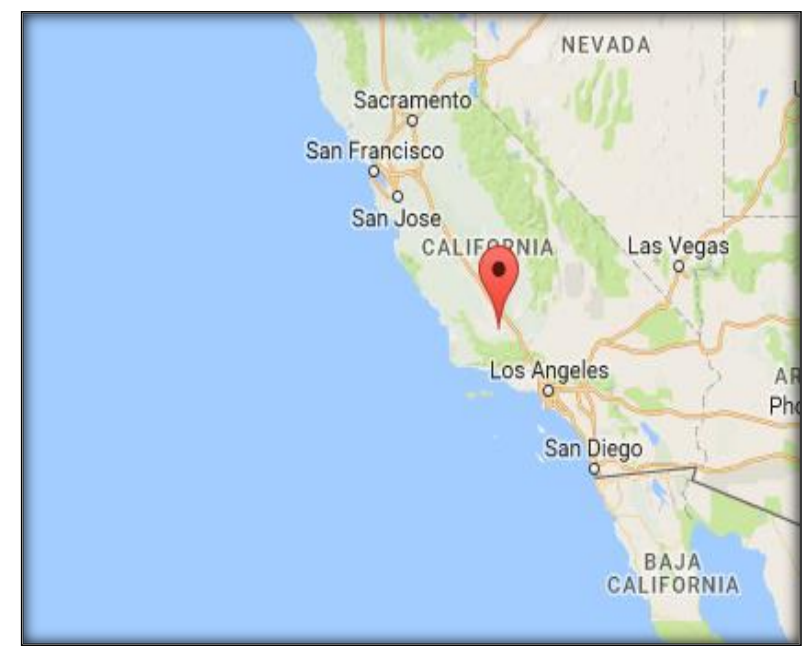

Figure 2.12: Berry Petroleum Thermal EOR Field at California [55]

Local oil producers in Kern County were seeking advanced technologies to economically produce from their heavy oil reserves which have been in production for over a century. Glasspoint partnering with local firms TJ cross engineers and PCL industrial services integrated the solar EOR system with existing facilities. This generates steam and preheated water at $190^{\circ} \mathrm{F}$ which is used as feedwater for the field's gas-fired generators. The efficiency and success of the first ever solar EOR unit at Berry petroleum helped GlassPoint solar land a contract to build a 7MW solar EOR for Petroleum Development Oman (PDO), the national oil company of Oman [56]. The glasspoint solar EOR system uses concentrated thermal energy from the sun thereby reducing the amount of natural gas burned for thermal EOR, releases gas for higher value applications, including power generation, desalination, industrial development and export. The resulting low-cost, emission free steam is fed directly into existing PDOs steam distribution network spanning more than 4 acres and producing 11 tons of high temperature $\left(312{ }^{\circ} \mathrm{C}\right)$, high pressure $(1,450 \mathrm{psi})$ steam per hour. The project at PDO is an estimated 27 times bigger than the Solar EOR at Berry petroleum, California. Glasspoint employs a unique single transit trough (STT) technology that encloses lightweight reflective mirrors inside a glasshouse structure. This protects the system from dirt, dust, sand, and humidity and reduces the natural gas usage for EOR by almost $80 \%$ in regions that are sunny. The STT technology combines existing proven 
technologies in high volume production worldwide with low-cost, light-weight components. This produces five times steam per acre than older power tower designs. Employing the solar EOR, Oman could effectively use gas for higher value applications thereby enabling other gas dependent industries to flourish [57]. 


\section{Chapter 3 SYSTEM DESCRIPTION}

\subsection{Solar Steam Generator}

For this given project, central tower is considered for the production of steam for thermal EOR. The system description of central tower is as follows.

\subsubsection{Heliostats}

Heliostat is the basic building block of central tower solar steam generator and consists of three major components namely drive, reflector module and structure. The control system commands drive that houses two motors. The motor enables heliostat to move in two different axes and track sun accurately throughout the day [58]. The pedestal supports the reflective surface that helps in the movement of heliostat about its elevation and azimuth axis. Fractional horsepower motor through gearbox drive helps in the movement about each axis [59]. The reflector module has mirror glass and metal frame attached to the drive. Heliostat is made of several glass mirror module panel with reflecting element of thin second black surface. Some of the heliostat uses thin reflective plastic membrane stretched over the hoop to protect it from the weather. This design is considerably less expensive and light weight however, cleaning and renewal is an important consideration. The mirror is slightly concave as glass mirror is supported by a backing substrate. This structure provide sturdy and rigid anchor to the heliostat. The individual panels on the heliostat are canted towards a point on the receiver. The focal length of the heliostat is equal to the approximate distance from receiver to the farthest heliostat [60]. The figure below shows backside of heliostat used at Solar One central receiver pilot plant in Barstow, CA. 


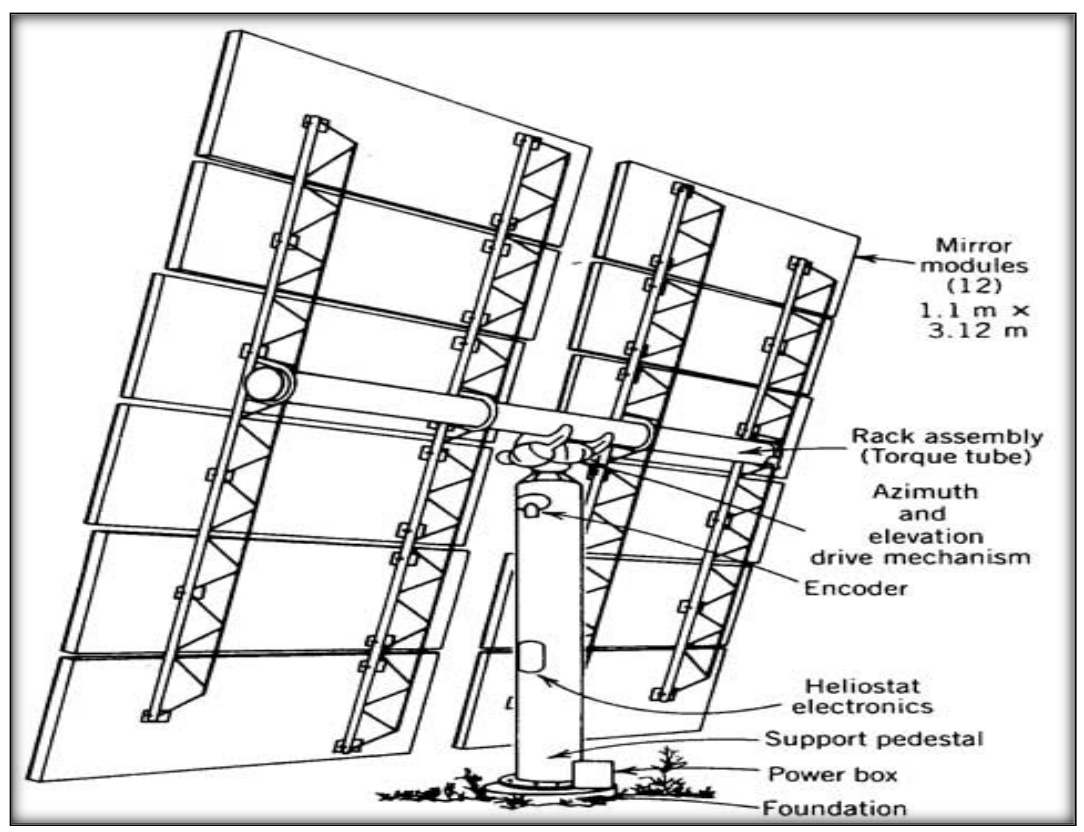

Figure 3-1 Parts of Heliostat [60]

The drive of heliostat is made of aluminum die cast, sintered metal and molded plastic components. Steel components and robotic welding are utilized in the making reflector module for high quality and repeatability. The stable and rigid structure utilizes progressive die stamping with robotic welding of steel components [58]. The reflective mirror is multilayered with silver providing high reflectivity in solar spectrum range. Protective layer of copper applied next to silver with prime coat, intermediate and protective top coat. The thickness of the complete mirror is approximately 4 to $5 \mathrm{~mm}$. The Figure below shows multilayers of the mirror used in a heliostat.

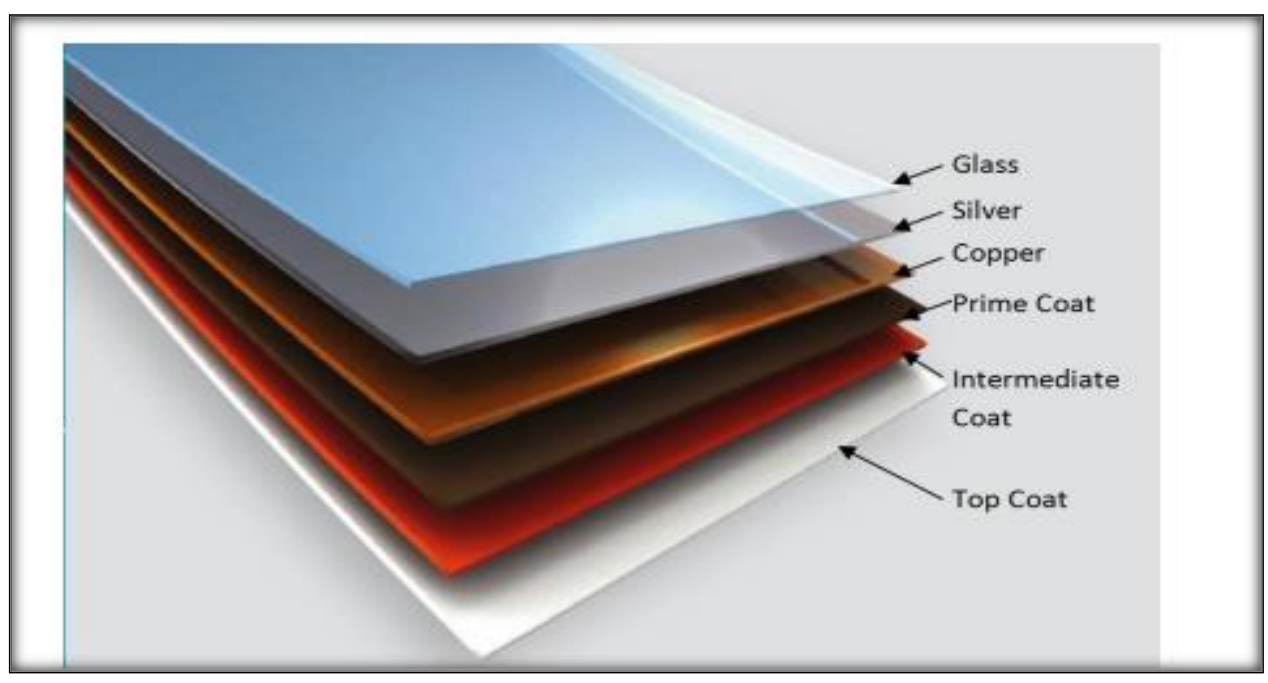

Figure 3-2 Multilayer of Mirror on Heliostat [61] 


\subsubsection{Receiver Tower}

The receiver is located at the top of the tower where the incident sun light from the heliostat can be most efficiently intercepted. The energy from the heliostat is transfer into heating the fluid flowing inside the receiver. The most commonly used receivers are external receivers that has panel of vertical small tubes welded to the side of the cylinder. These vertical tubes are connected to the headers to supply fluid (water) from the bottom of each tube and collect heated fluid from the top. The figure below shows an external receiver with 24 panels each $13.7 \mathrm{~m} \mathrm{(45}$ ft.) high, consisting of 70-12.7 mm (1/2 in.) diameter tubes. Six of these panels preheat water and eighteen produce steam. This receiver is mounted on a tower of $77.1 \mathrm{~m}$ (253 ft.) height. These tubes are coated with black paint and are made of Incoloy 800. The total diameter of the receiver is $7 \mathrm{~m}(23 \mathrm{ft}$.$) .$

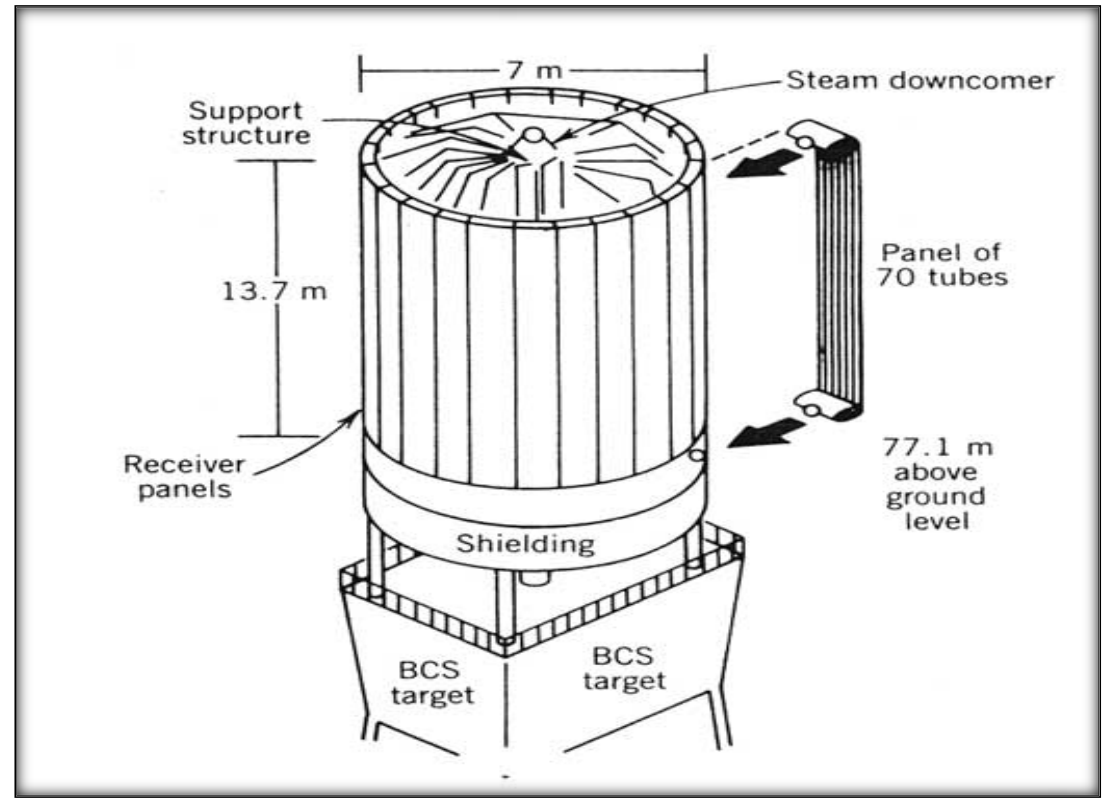

Figure 3-3 Sections of Receiver Tower

The height to diameter ratio of external receiver is $1: 1$ to $2: 1$. To reduce heat loss, area of receiver is kept to minimum. By knowing the operating temperature of the tubes and heat transfer capacity of the fluid, lower limit is determined. For example, if liquid sodium is used as heat transferring fluid, height and diameter of the receiver is approximately $15 \mathrm{~m}$ (49 ft.) vs $13 \mathrm{~m}$ (41 ft) with peak output of $380 \mathrm{MW}(1.3 \times 109 \mathrm{Btu} / \mathrm{h})$. However, if water is used as the transfer fluid, twice the area would be required due to the lower heat transfer capabilities. 


\subsubsection{Tower Design}

For the design of the tower, weight of the receiver and windage area are the most important factors. The height of the tower is cost dependent and ranges from 140 to $170 \mathrm{~m}$ (460 to $560 \mathrm{ft}$ ). The fluid choice affects the size and weight of the receiver on the top of the tower. The construction material for the tower is steel frame or concrete. Cost analysis indicate that concrete towers are cheaper for higher towers and steel frame towers are cost efficient for height less than $120 \mathrm{~m}(400 \mathrm{ft})$. The weight of the receiver on top of the tower ranges from $250,000 \mathrm{~kg}$ $(550,000 \mathrm{lb})$ to $2,500,000 \mathrm{~kg}(5,500,000 \mathrm{lb})$ [60]. In places where this project is constructed and where high sand and dust is experienced, robotic cleaning system is installed. This uses high pressure water to clean mirror surface without coming in contact with the reflective mirror. With this technology, high temperature solar steam recovery is maintained by proving maximum reflective energy. This does not require an enclosed glass house and can be deployed on an uneven terrain with high reliability and simple operation [62].

\subsection{Heat Recovery Steam Generator}

\subsubsection{Economizer}

The first primary part of HRSG circuit is economizer. The capacity of the economizer is to bring feed water to an approach temperature close to saturation temperature at which maximum heat energy can be absorbed leading to efficiency and operational adaptability. They act like once through heat exchangers and can be intended for steaming or non-steaming. The ones used in HRSG are non-steaming based on water quality, boiler life, heat optimization and operational consideration. An economizer is called as steam economizer when absorption of heat energy from high exhaust gas flows across water to produce steam. The figure below illustrates the process occurring in an economizer. Section of the economizer is made out of finned tube surface modules including drains and vents. These modules are arranged parallel to reach desire capacity and water temperature. The Drum control helps economizer to achieve water flow rate control [63]. 


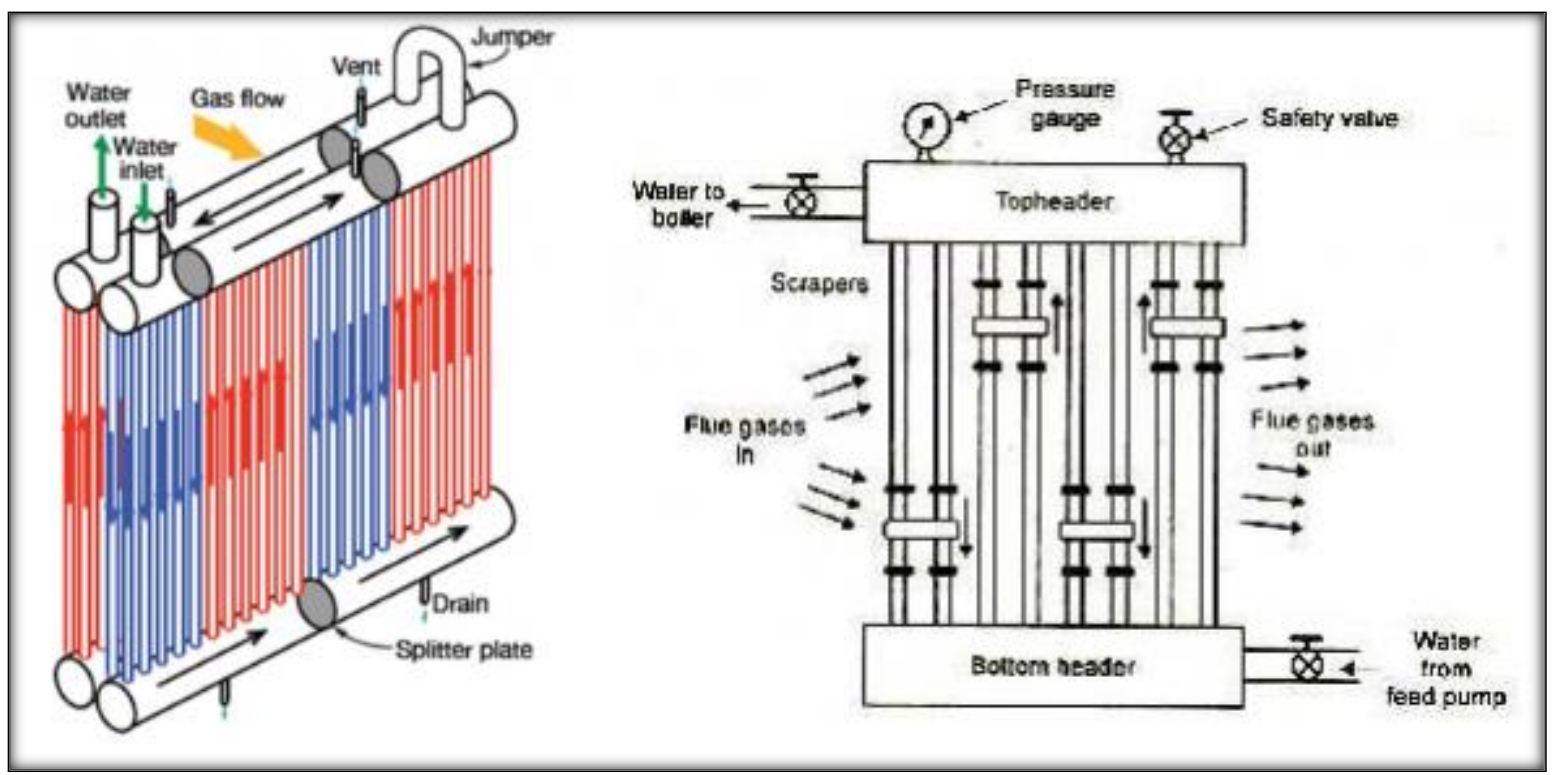

Figure 3-4 Side Section and Cross Section of Economizer [64] [65]

Based on the pressure system of HRSG, there can be a single or dual economizer in the circuit. In dual pressure HRSG, there is a high pressure economizer and in three pressure HRSG, there is high and intermediate economizer. In high pressure economizer, each module is single pass on gas side and multipass on water side. The feed water received by feed pump absorbs heat from exhaust gas raising the water temperature to near saturation further directing it to the high steam drum [63].

\subsubsection{Steam Drum}

Steam drums operating in HRSG are equipped at high, intermediate and low pressure and are used for steam water separation, water storage and purity of steam control. The riser tube allows the steam water mixture to enter the drum and has approximately $5-10 \%$ of steam depending on the pressure and load of the boiler. The low percentage of steam in the mixture prevents the boiler tubes from overheating and leading to failure. When the mixer comes to the steam drum, the saturated steam separates from the mixture and rises to the top of the drum. The remaining water with feedwater from economizer enters the evaporator where heat is absorbed by the water from evaporator tubes. The steam water separation occurs with the combination of mechanical components and gravity. The separation of this mixture depends on the distinct level in the drum called as normal water level. There are two steps by which this separation occurs. In primary separation, centrifugal separator removes almost all the water however; some water traces are left which has to be removed before steam goes to the superheater. For that purpose, 
secondary separation or steam scrubbing is carried out. The cyclone separator in primary separation is cylindrical in shape and is placed inside the drum along its length. With the rise tubes, the mixture enters this separator tangentially and the centrifugal force throws water against the cylinder wall. As water is denser than steam, the water flows down by gravity and steam moves to the center of the cylinder to rise above. The water discharges from cyclone separator through annulus. The steam passes through the corrugated scrubbers for secondary separation on the top of the cylinder. The scrubber removes any small amounts of contaminants and water. Steam drum contains control instruments such as relief valves, pressure indicator, riser pipes, downcomers and blowdown [63].

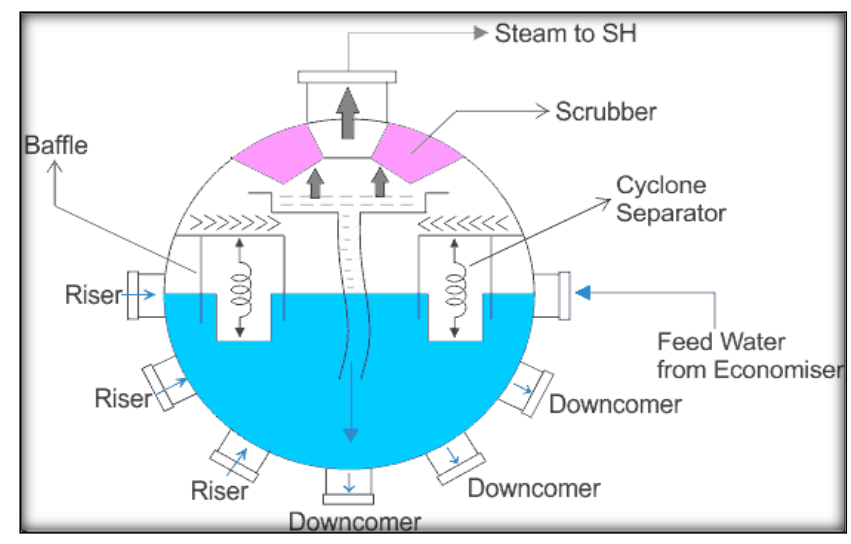

Figure 3-5 Cross Section of Steam Drum [66]

The high/low pressure drum gets feed water from high/low pressure economizer and mixes it with the water in the drum. Through the downcomers, water from the drum is fed to the bottom of high/low pressure evaporator. Natural loop is completed when steam and water steam mixture flows to steam drum through evaporator modules [63].

\subsubsection{Evaporator}

The steam generation and the boiling process occur in the evaporator. The heat energy from the gas stream is absorbed by water causing the temperature to increase. When this temperature reached the saturation temperature, water starts to boil and some of the water evaporates to steam. The water is fed into the evaporator through downcomer and the mixture of water steam leaves for steam drum via riser system. The continuous circulation of water entering the evaporator and leaving with a mixture of water steam is called natural circulation loop [63]. 


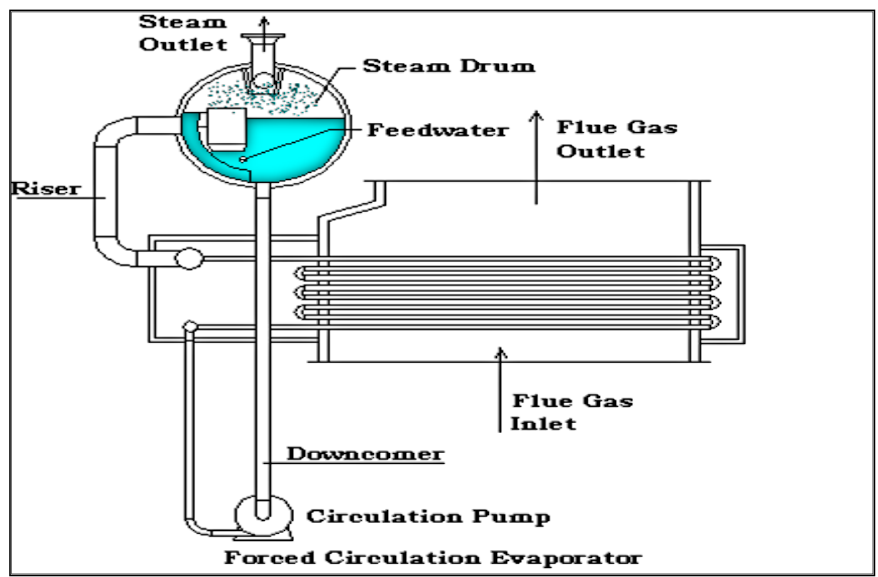

Figure 3-6 Cross Section of Evaporator [67]

\subsubsection{Superheater}

Superheater is the last component of steam generator circuit. It is used to increase the steam temperature above saturation. Steam cycle efficiency is improved as introduction of water into the injection well is minimized due to high temperature steam. The heat from the exhaust gas is absorbed by the superheater and this energy is transferred to steam. The section of superheater is made of finned tube surface modules with high metal temperature and arranged in parallel or series configuration to obtain desired temperature and capacity. Some water or condensate can be formed in the lower module header as a result of purge of warm start. This can be removed by drainable superheater. In the high pressure superheater, steam is received at saturated temperature from high pressure steam drum and heated to final steam temperature [63].

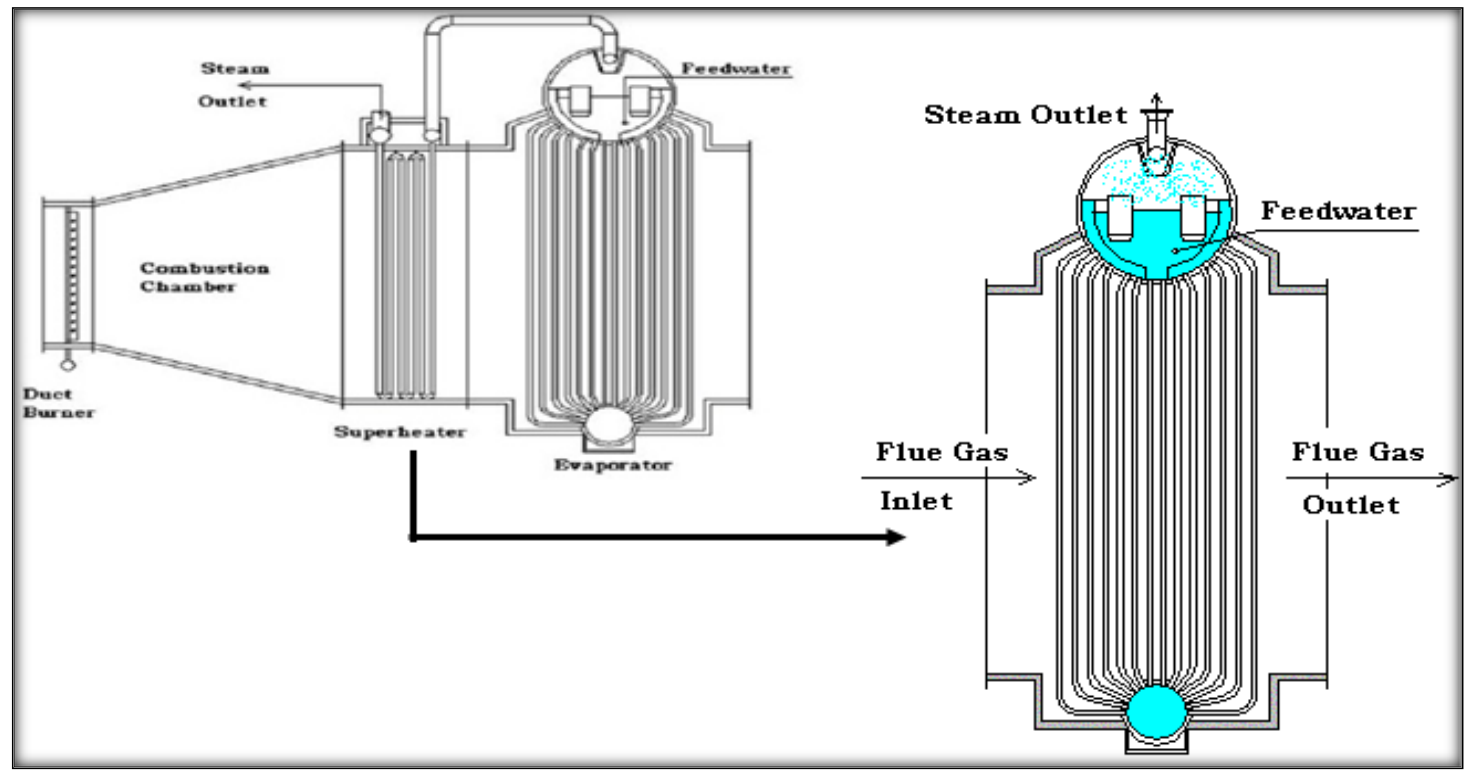

Figure 3-7 Cross Section of Super Heater [68] [69] 


\section{Chapter 4 MECHANISM}

\subsection{Steam Generation by Solar Power}

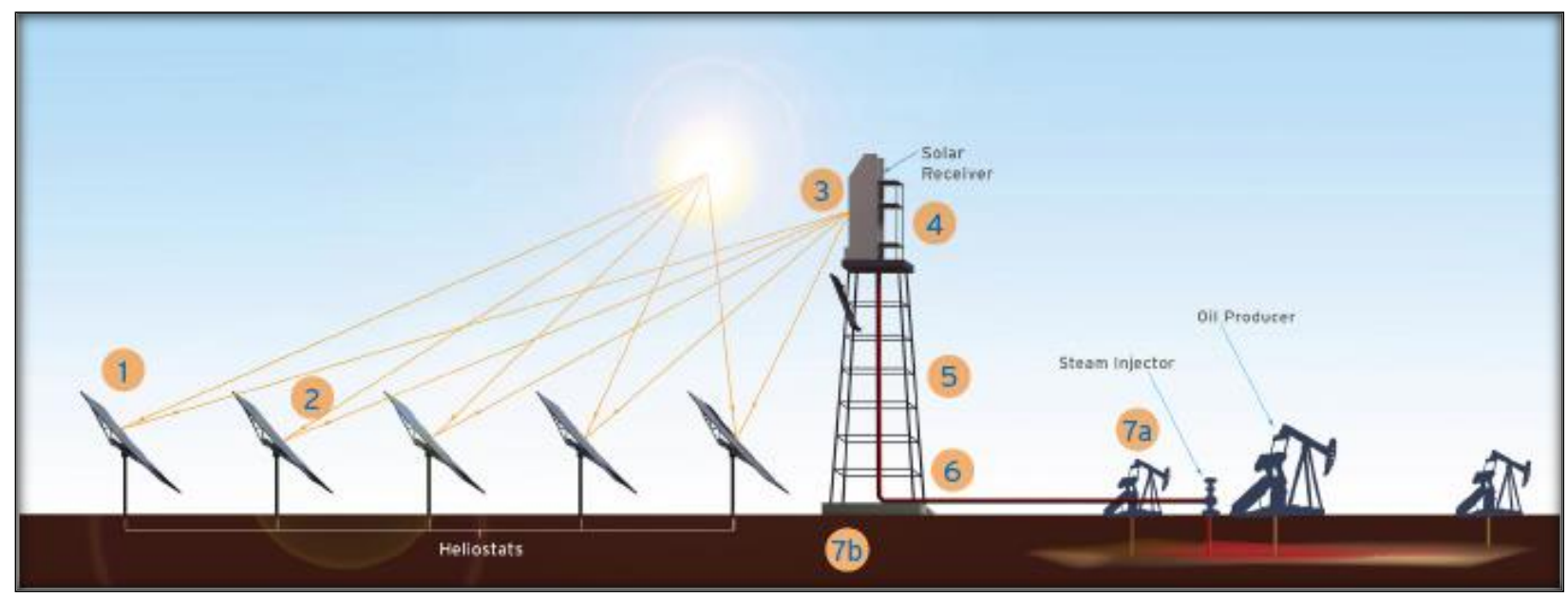

Figure 4-1 Solar Steam Generation Mechanism

1. The heliostats are reflective mirrors that follow sun rays throughout the day.

2. The reflective mirrors capture the light energy from sun and convert it into heat energy.

3. At the top of the tower is receiver where, light is reflected from heliostats.

4. The water is converted into process steam and heated to high temperature with heat energy in the receiver.

5. The process steam is directed to heat exchangers at the bottom of the tower.

6. Inside the heat exchangers, the close loop system of pipe holds water obtained from oil production. The heat of process steam converts water into steam which is called saturated steam. 7a. The saturated steam is sent to the distribution system where it is sent to oil fields and injected into the reservoir through injection wells.

7b. Process steam cools down, becomes water and is sent to the boiler unit at the top of the tower into the receiver and this entire process is repeated [70]. 


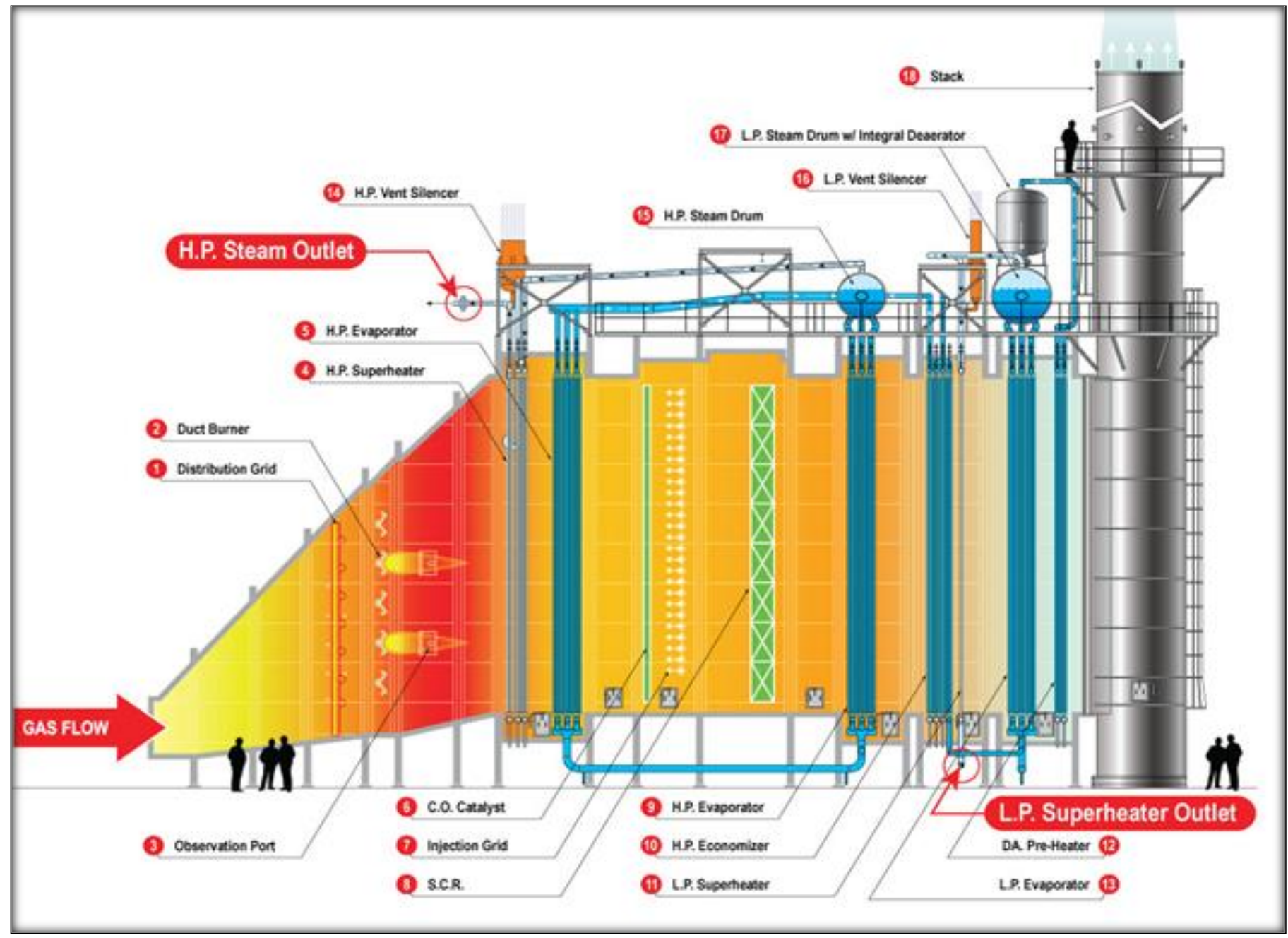

Figure 4-2Heat Recovery Steam Generation Mechanism [71]

Heat Recovery Steam Generators (HRSG) is basically a heat exchanger that absorbs and recovers heat from the exhaust gas stream to generate 1150 psia and 515 degree Fahrenheit steam. This steam is then directed to injection wells to be injected into the reservoir for the thermal enhanced oil recovery. As per the above figure, the numbers in the mechanism below are based on the flow path.

1. There are two flow paths in HRSG firstly, gas flow that starts from combustion turbine outlet to distribution grid (1) and finally to outlet stack (14). Secondly, water flow that starts from feed water pre-heater and moves through gas flow path to be converted into steam. This steam is directed to injection wells through high pressure steam outlet. 
2. The gas flows across the duct burner (2) typically located between HP superheated sections (4), where gas is burnt and temperature reaches to 1500 degree Fahrenheit.

3. Observation port (3) provides complete assess to burner, furnace and convention section.

4. Feed water preheater (12) is where condensate water enters to be preheated and directed into low pressure steam drum (17). In the LP steam drum, preheated water mixes with the water (already in the drum) and leaves for low pressure evaporator (13) via downcomers.

5. Low pressure evaporator (13) is the place where steam is generated. This steam enters the LP steam drum again where separation between water and steam occurs. The recirculation between water-steam mixture and water produces saturated steam. This steam exits the steam drum to enter the high pressure superheater where it is heated to final steam temperature.

6. High pressure economizer (10) gets feed water from LP drum. The control valves control the entry of this water into HP steam drum (15) from the economizer. In the HP steam drum, feedwater mixes with the water (already in the drum) and leaves for high pressure evaporator (9). High pressure evaporator generates steam and this steam enters the HP steam drum. Recirculation produces saturated steam and transferred to high pressure superheater (4).

7. High pressure superheater absorbs the heat energy from the exhaust gas and increases the temperature of the steam making it superheated.

7. The superheated steam (4) is then routed to injection wells.

8. High pressure vent silencer (14) reduces the unwanted noise in the pipelines created by high velocity flow of stream or gas.

8. SCR catalyst (6) is made of ceramic elements that are compact, homogeneous and honeycomb structure. They are mixture of titanium dioxide, tungsten oxide, and vanadium pentoxide. The temperature in this section ranges from 635 to 675 degree Fahrenheit.

9. Selective catalytic reduction (S.C.R) system (8) removes NOx (NO and NO2) with Aqueous ammonia (NH3) as reducing agent [63]. 


\section{Chapter 5 CHAPTER V. METHODOLOGY}

\subsection{Steam from Solar Powered Generator}

As the heat energy converts water to steam, following methodology is used to calculate total heat in BTU/Hr. required to further convert 10 gals of cold water to steam at 450 degree Fahrenheit and 414.7 psia.

Heat to raise water temp to boiling point $\rightarrow$ Heat to convert water to steam $\rightarrow$ Heat to increase the temperature and pressure of steam

1. If the available solar power density is $1.0 \mathrm{kWh} / \mathrm{hr} / \mathrm{m}^{2}$, a solar collector can absorb 3412 $\mathrm{BTU} / \mathrm{hr} / \mathrm{M}^{2}$. Power available from the sun, as stated above, can be expressed in terms of BTUs per hour per square meter $\left(\mathrm{btu} / \mathrm{hr} / \mathrm{m}^{2}\right)$.

2. When water is boiling in a closed container, the temperature of the steam will not increase as heat is added until all the water in the container has turned to steam. Heat required to convert water from its boiling temperature to steam is called the Latent Heat of Vaporization and has a value of $970 \mathrm{BTU} / \mathrm{lb}$ for water at atmospheric pressure. What this means is for every pound of water, 970 BTU is needed to convert water into steam at 212 degree Fahrenheit. Heat of Vaporization for water equals 970 BTU/lb [72].

3. As the steam condition at the surface is 450 degree $\mathrm{F}$ and 414.7 psia, it is important to know the energy in BTU/hr to produce steam at the given conditions. For this, superheated steam table is used with safety factor assuming to be 1.2 and $80 \%$ quality of steam is produced

\subsection{Steam from Natural Gas Powered Generator}

1. Steam table at operating pressure of 1150 psia and feed water temperature at 515 degree Fahrenheit with energy content of natural gas (BTU/Sales unit) is referred to calculate the amount of steam generated per MMCF of natural gas [73]

2. Total cost set up of plant is calculated in USD/KW and converted into USD/BTU to calculate the cost per lb. of steam from natural gas.

3. From step 1, amount of steam (lb.) generated is calculated from 1 BTU of energy.

4. To get the cost per lb. of steam generation by natural gas, divide step 2 by step 3 


\section{Chapter 6 ASSUMPTION}

\subsection{Steam from Solar Powered Generator}

1. For the calculation of total amount of heat in BTU required to heat water at $70 \mathrm{deg}$. Fahrenheit into superheated steam at 450 degree Fahrenheit, small scale solar powered generator is assumed in operation. Additionally the rate of incoming water is assumed to be 10 gallons/min.

2. Only one heliostat is assumed which is $13.98 \mathrm{~m}^{2}$ in area that strikes the sun rays onto the receiver for conversion of water into steam.

3. For heating the steam to 450 degree $\mathrm{F}$, it is assumed that the quality of steam produced is $80 \%$. The efficiency of this system is assumed to be $39 \%$ with 320 days of operation.

4. The total cost of investment, installation, operation and maintenance was found for a solar steam generation plant of $50 \mathrm{KW}$. It is assumed that economy of scale will be constant all these cost in USD is calculated per KW.

\subsection{Steam from Natural Gas Powered Generator}

1. The efficiency of the process is assumed to be $85 \%$ as not all the natural gas from pipelines or tankers is used for the conversion of water into steam. 


\section{Chapter 7 CALCULATIONS}

\subsection{Steam from Solar Powered Generator}

The steps below determine the heat required to raise 10 gallons of water from 70 degree Fahrenheit to the boiling point of 212 degree Fahrenheit:

$\underline{\text { STEP-1 }}$ Total weight of water $=10$ gal x $8.3 \mathrm{lbs} . /$ gal $=83 \mathrm{lbs}$.

Temperature change $=\mathrm{T} 2-\mathrm{T} 1=212-70=142$ degree Fahrenheit.

$\mathrm{H}_{\mathrm{w}}$, the total heat required to heat the water $=1 \mathrm{BTU} / \mathrm{lb}-\mathrm{deg} \times 83 \mathrm{lb} . \times 142 \mathrm{deg}=11,786 \mathrm{BTU}$

Available solar power density is $1.0 \mathrm{kWh} / \mathrm{hr} . / \mathrm{m}^{2}$, a solar collector can absorb $3412 \mathrm{BTU} / \mathrm{hr} . \mathrm{M}^{2}$.

Therefore, heat per hour: $\mathrm{H}_{\mathrm{h}}=3,412 \frac{\mathrm{BTU}}{\mathrm{hr} \times \mathrm{M}^{2}} \times 13.98 \mathrm{M}^{2}=47,699 \mathrm{BTU} / \mathrm{hr}$.

Therefore, it will take $\mathrm{T}_{\mathrm{h}}$ hours, where: $\mathrm{T}_{\mathrm{h}}=\mathrm{H}_{\mathrm{w}} / \mathrm{H}_{\mathrm{h}}=11,786 \mathrm{BTU} \div 47,699 \mathrm{BTU} / \mathrm{hr}=0.24 \mathrm{hrs}$.

Total Heat per hour $=11,786 \div 0.24 \mathrm{hrs}=49,108 \mathrm{BTU} / \mathrm{hr}$.

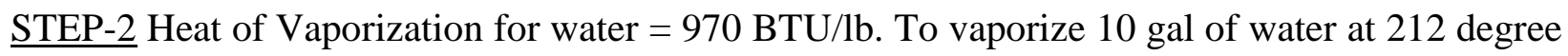
to steam, the following amount of heat is needed:

$\mathrm{H}_{\mathrm{v}}=10$ gal $\times 8.3 \mathrm{lb} /$ gal $\times 970 \mathrm{BTU} / \mathrm{lb}=80,510 \mathrm{BTU}$

Available solar power density is $1.0 \mathrm{kWh} / \mathrm{hr} . / \mathrm{m}^{2}$, a solar collector can absorb 3,412 BTU/hr./M².

Therefore, heat per hour: $\mathrm{H}_{\mathrm{h}}=3,412 \frac{\mathrm{BTU}}{\mathrm{hr} \times \mathrm{M}^{2}} \times 13.98 \mathrm{M}^{2}=47,699 \mathrm{BTU} / \mathrm{hr}$.

The time required to make $83 \mathrm{lbs}$. of steam from 10 gals of water at the boiling point is:

$\mathrm{T}_{\mathrm{v}}=80,510 \mathrm{BTU} \div 47,699 \mathrm{BTU} / \mathrm{hr}=1.68$ hours

Total Heat per hour $=80,510 \div 1.68=47,922 \mathrm{BTU} / \mathrm{hr}$.

\section{$\underline{\text { STEP-3 }}$}

$83 \mathrm{lbs}$. of $80 \%$ steam is further heated to 450 degree $\mathrm{F}$ at 414.7 psia.

First plot the pressure on graph as $\mathrm{P}$ and steam quality on graph as Q. Draw a straight line through P and Q to get W1. W1= 25 watts/hr./lb.

Plot the degree of superheat on graph $\mathrm{S}$. The degree of superheat equals operating temperature minus saturated temperature. $\mathrm{S}=450-212=238$ degree $\mathrm{F}$

Draw a straight line through P and S to get W2. W2=120 watts/hr./lb.

Safety Factor is assumed to be 1.2

Required KW/hr $=83 \mathrm{lb} . \times \frac{(120-25) \text { watts }}{h r \times l b} \times \frac{1}{1000} \times 1.2=9.46 \mathrm{KW} / \mathrm{hr}$

To convert kW to BTU simply multiplies by 3412 .

Total heat per hour $=9.46 \times 3412=\mathbf{3 2 , 2 8 4} \mathrm{BTU} / \mathrm{hr}$. 


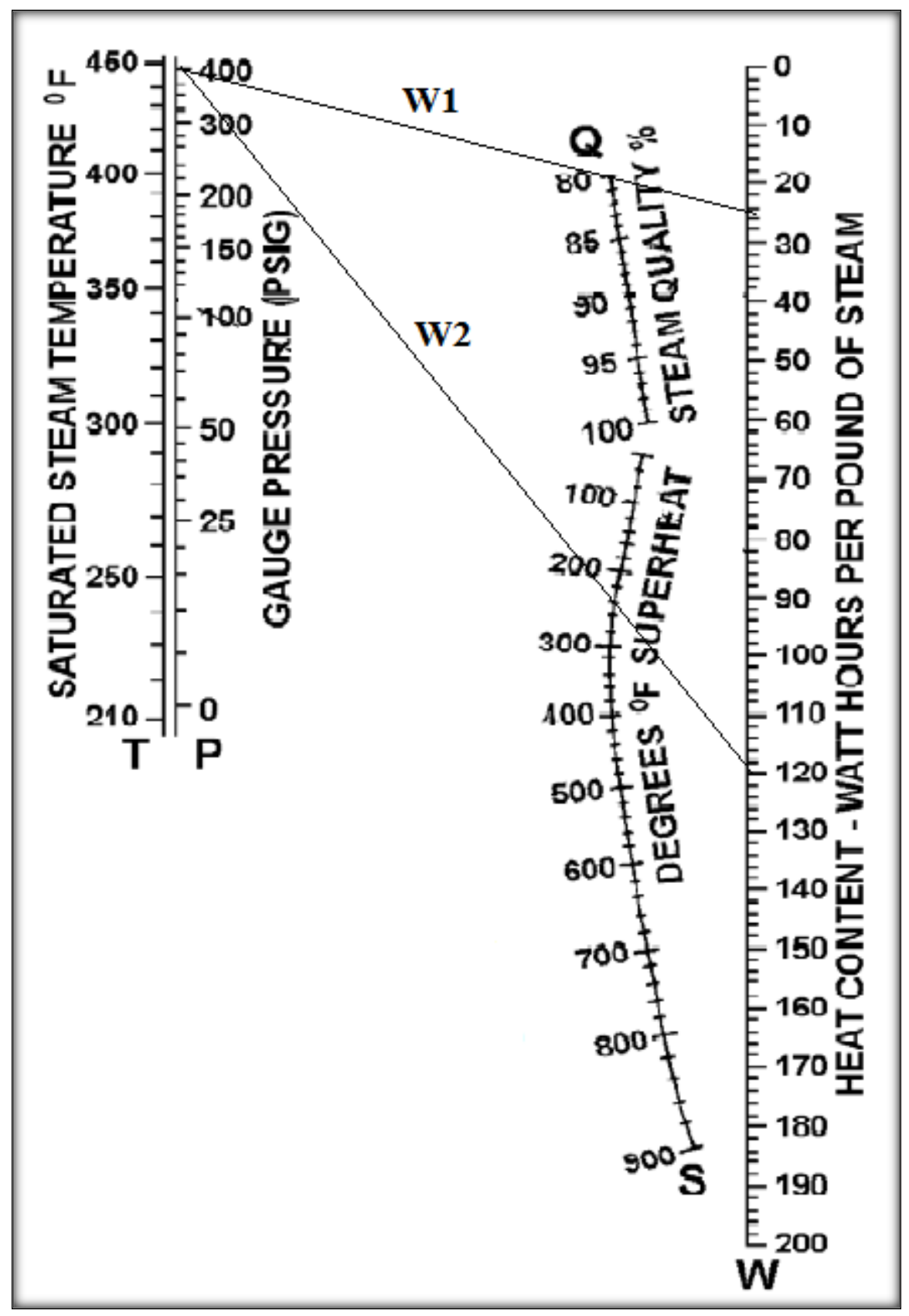

Figure 7-1 Steam Superheat Nomograph [73]

Total heat required $=49,108+47,922+32,284=129,314 \mathrm{BTU} / \mathrm{hr}$.

Therefore to calculate how much amount of steam was produced-

$$
\frac{129,314 B t u}{h r} \times \frac{L b}{1206 B t u} \times 0.39=41.81 \text { lb of steam per hour of solar energy }
$$

$1206 \mathrm{Btu} / \mathrm{lb}$ is obtained from superheated steam table at 414.7 psia and 450 degree F. [73] 
Assuming there are 6000 collectors each with a $13.98 \mathrm{~m}^{2}$ area, total steam generated at an average of 8 hours per day directly from sun and rest 16 hours from storage unit for a year $=$ $6000 \times 41.81 \times 24 \times 320=1,926,604,800 \mathrm{lb}$.

The amount of steam generated per BTU $=41.81 \div 129,314$ or

$1,926,604,800 \div[(1,926,604,800 \times 129,314) \div 41.81]=\underline{3.233 * 10^{-4} \mathrm{lb} . / \text { Btu }}$

Average Cost $=$ Total Cost/Total Steam, USD/LB [74]

Total Cost $=$ Investment+ Installation + Operation and Maintenance

Total Cost $=25,749$ USD $/ \mathrm{KW}=25,749 \div 3412=\underline{7.54 \mathrm{USD} / \mathrm{BTU}}$

$\underline{\text { Average Cost per Lb. of steam }}=7.54 \mathrm{USD} / \mathrm{BTU} \div 3.233 \times 10^{-4} \mathrm{lb} / \mathrm{BTU}=\underline{\mathbf{\$ 2 3}, \mathbf{3 2 1} / \mathbf{L b}}$.

\begin{tabular}{|l|r|}
\hline \multicolumn{2}{|c|}{ Investment Cost } \\
\hline Labour Cost: Site and Solar Field & USD/KW \\
\hline Solar Field & 1248 \\
\hline Site Prep and Infrastructure & 226 \\
\hline Steel Construction & 424 \\
\hline Piping & 128 \\
\hline Electric Installation and others & 288 \\
\hline Equipment: Solar Field and HeatTransfer System & USD/KW \\
\hline Mirror & 462 \\
\hline Receiver & 518 \\
\hline Steel Construction & 780 \\
\hline Pylon & 6 \\
\hline Foundation & 156 \\
\hline Motors & 32 \\
\hline Swivel Joint & 52 \\
\hline HTS (pipipng, insulation, heat exchangers and pump) & 390 \\
\hline Storage System & $\mathrm{USD} / \mathrm{KW}$ \\
\hline Storage Tanks & 132 \\
\hline Insulation Material & 14 \\
\hline Foundation & 46 \\
\hline HeatExchangers & 102 \\
\hline Pumps & 32 \\
\hline Others & $\mathrm{USD} / \mathrm{KW}$ \\
\hline Project Developnment & 210 \\
\hline Project Management & 562 \\
\hline Financing & 436 \\
\hline Other Cost (Allowance) & 210 \\
\hline Total & 6454 \\
\hline & \\
\hline
\end{tabular}




\begin{tabular}{|l|r|}
\hline Installation Cost & USD/KW \\
\hline Parabolic Trough & 7100 \\
\hline Solar Tower & 9000 \\
\hline Heat Transfer System & 1068 \\
\hline Thermal Energy Storage & 2020 \\
\hline Total & 19188.398 \\
\hline
\end{tabular}

\begin{tabular}{|l|r|}
\hline O\&M Cost & USD/KW \\
\hline Onsite Staff & 54 \\
\hline Utilities- Water & 0.42 \\
\hline Consumables & 9 \\
\hline Maintenance \& Repairs & \\
\hline Solar Field & 10.16673 \\
\hline HTF System & 3.152816 \\
\hline TES System & 3.533233 \\
\hline Power Block & 23.0058 \\
\hline Water Treatment & 0.845592 \\
\hline Office \& Administration & 1.07034 \\
\hline Training & 0.824515 \\
\hline Contract Services & 0.382922 \\
\hline Miscellaneous Cost & 1.160709 \\
\hline Total & 107 \\
\hline
\end{tabular}

\begin{tabular}{|ll|l|}
\hline Total Cost, USD/KW & 25749 & USD/KW \\
\hline
\end{tabular}

Table 7-1 Total Cost of Steam Generation by Solar [75]

\subsection{Steam from Natural Gas Powered Generator}

To calculate the amount of steam from the required natural gas, following tables were referred to-

\begin{tabular}{|c|c|c|}
\hline Fuel Type, sales unit & $\begin{array}{c}\text { Energy Content, } \\
\text { Btu/sales unit }\end{array}$ & $\begin{array}{c}\text { Combustion } \\
\text { Efficiency, \% }\end{array}$ \\
\hline Natural Gas, MMBtu & $1,000,000$ & 85.7 \\
\hline $\begin{array}{c}\text { Natural Gas, thousand cubic } \\
\text { feet }\end{array}$ & $1,030,000$ & 85.7 \\
\hline
\end{tabular}

Table 7-2 Energy Content and Combustion Efficiency of Fuels [76]

$\underline{\text { Step } 1}$ Referring the tables above, $1030 \times 10^{6} \mathrm{Btu}$ of energy is produced per MMcf of natural gas and $943 \mathrm{Btu}$ energy is required to produce $1 \mathrm{lb}$. of steam. 
$943 \mathrm{Btu} / \mathrm{lb}$ is obtained from superheated steam table at 1150 psia and 515 degree F [73]. The amount of steam generation per MMCF of natural gas is calculated as follows-

$$
\frac{1030 \times 10^{6} \mathrm{Btu}}{M M c f} \times \frac{\mathrm{Lb}}{943 \mathrm{Btu}} \times 0.85=928,420 \mathrm{lb} \text { per MMcf of natural gas }
$$

$\underline{\text { Step } 2}$ Total Plant cost equals $=4495 \$ / \mathrm{KW}=4495 / 3412 \$ / \mathrm{BTU}=\$ 1.32 / \mathrm{Btu}$

\begin{tabular}{|l|r|}
\hline Investment Cost & USD/KW \\
\hline Civil/Structure & 80 \\
\hline Mechanical Gas Turbine & 584 \\
\hline SCR & 60 \\
\hline Gas Compressor & 128 \\
\hline Electrical & 110 \\
\hline Piping & 28 \\
\hline Instruments and Controls & 18 \\
\hline Natural Gas & 1075.2 \\
\hline Balance of Plant/General Facilities & 68 \\
\hline Total & $\mathbf{2 1 5 1 . 2}$ \\
\hline
\end{tabular}

\begin{tabular}{|l|r|}
\hline Maintenance \& Repairs & USD/KW \\
\hline Water Treatment & 0.845592 \\
\hline Office \& Administration & 1.07034 \\
\hline Training & 0.824515 \\
\hline Contract Services & 0.382922 \\
\hline Miscellaneous Cost & 1.160709 \\
\hline Indirect Costs & 56 \\
\hline Engineering and Home Office Costs & 126 \\
\hline Project Contingency & 188 \\
\hline Gas Turbine Cost & 560 \\
\hline Total & $\mathbf{9 3 4}$ \\
\hline
\end{tabular}

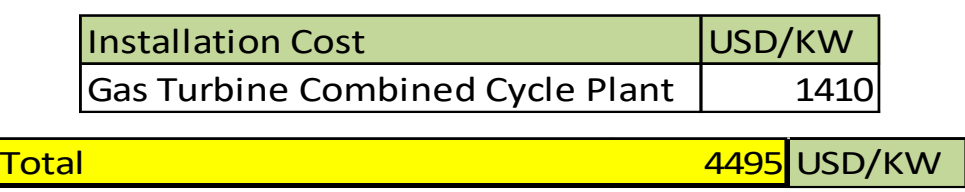

Table 7-3 Total Cost of Steam Generation by Natural Gas [75] [76]

$\underline{\text { Step } 3} 928,420 \mathrm{lb}$ Steam is generated from $1030 \times 10^{6} \mathrm{Btu}$ natural gas. Which means $9.01 \times$ $10^{-4} l b$ of steam is generated from 1 Btu of natural gas.

Step 4 Therefore,

$\frac{\$ 1.32}{B t u} \times \frac{B t u}{9.01 \times 10^{-4} l b}=\frac{1,465 \$}{l b}$ of steam generated from natural gas. 
To further calculate the NPV for the SSG and HRSG, nominal discount rate is assumed $10 \%$ with inflation rate of $4 \%$. From nominal discount rate and inflation rate, real discount rate is calculated to be used in finding NPV. The NPV for both these cases are shown below.

\begin{tabular}{|r|r|}
\hline \multicolumn{2}{|c|}{ Solar } \\
\hline Year & Cash Flow \\
\hline 0 & -10693 \\
\hline 1 & -22972 \\
\hline 2 & -21099 \\
\hline 3 & -19225 \\
\hline 4 & -17352 \\
\hline 5 & -15478 \\
\hline NPV & $\$(93,078.23)$ \\
\hline
\end{tabular}

\begin{tabular}{|r|r|}
\hline \multicolumn{2}{|c|}{ Natural Gas } \\
\hline Year & Cash Flow \\
\hline 0 & -5960 \\
\hline 1 & -526 \\
\hline 2 & 1348 \\
\hline 3 & 3221 \\
\hline 4 & 5095 \\
\hline & 6968 \\
\hline NPV & \\
\hline
\end{tabular}

Table 7-4 Cash Flow for SSG and HRSG 


\section{Chapter 8 RESULTS}

For the $1^{\text {st }}$ case of generation of steam by solar plant, the total cost of steam is calculated to be $\$ 23,321$ per $\mathrm{lb}$. and the total cost of plant for this operation is $\$ 25,749$ per $\mathrm{KW}$. For case $2^{\text {nd }}$ of generation of steam by natural gas, total cost of steam is $\$ 1,465$ per lb. and total cost of plant for this operation is $\$ 4,495$ per $\mathrm{KW}$. With time in different countries, the cost of natural gas changes. The calculation was specific to plant cost and upon increased price of natural gas, the cost difference of the production of steam decreases making solar steam generators more competitive.

The Summary of results is shown in the table below-

\begin{tabular}{|l|r|r|}
\hline RESULTS & Steam Cost, USD/Lb & Total Plant Cost, USD/KW \\
\hline Solar & $\$ 23,321$ & $\$ 25,749$ \\
\hline Natural Gas & $\$ 1,465$ & $\$ 4,495$ \\
\hline
\end{tabular}

Table 8-1 Summary of Results 


\section{Chapter 9 DISCUSSION}

\subsection{Locations for the Setup of Solar EOR}

As discussed in the introduction and from the figures below, the global heavy oil reserves is as follows-

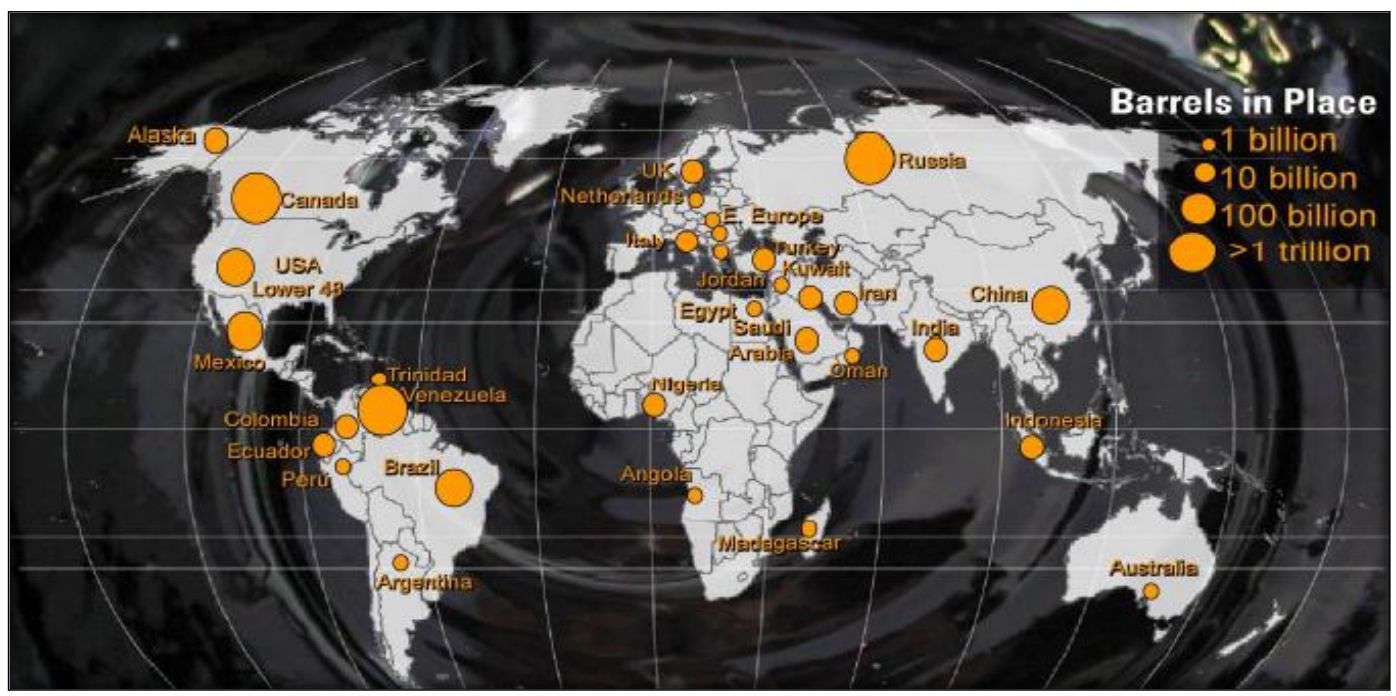

Figure 9-1 Global Heavy Oil Resources in Barrels in Place

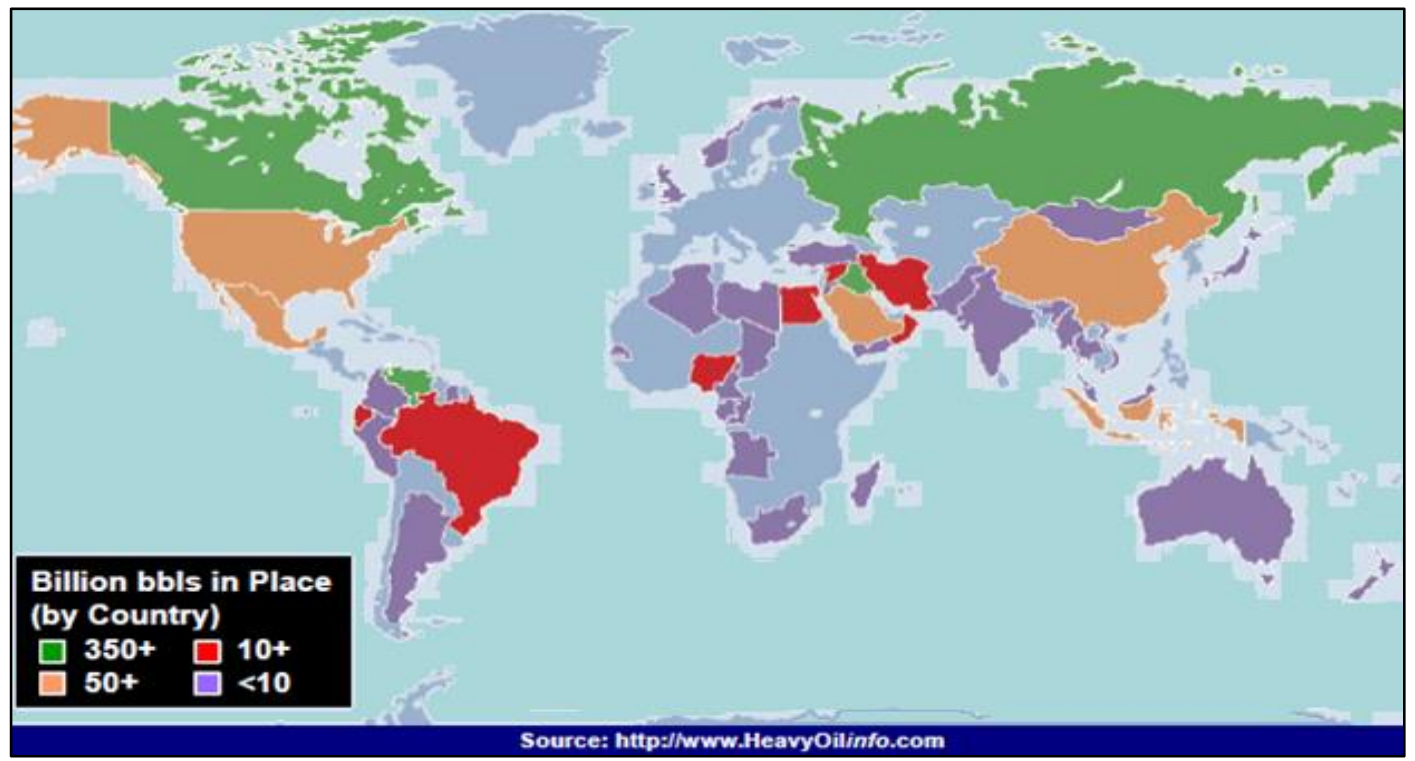

Figure 9-2 Global Heavy Oil Resources in Barrels in Place by Country [5]

It is important to analyze which place is most suitable for the setup of solar steam generation plant based on the annual solar radiance, while comparing the heavy oil resources. Global sum of direct irradiance is shown in the figure below- 


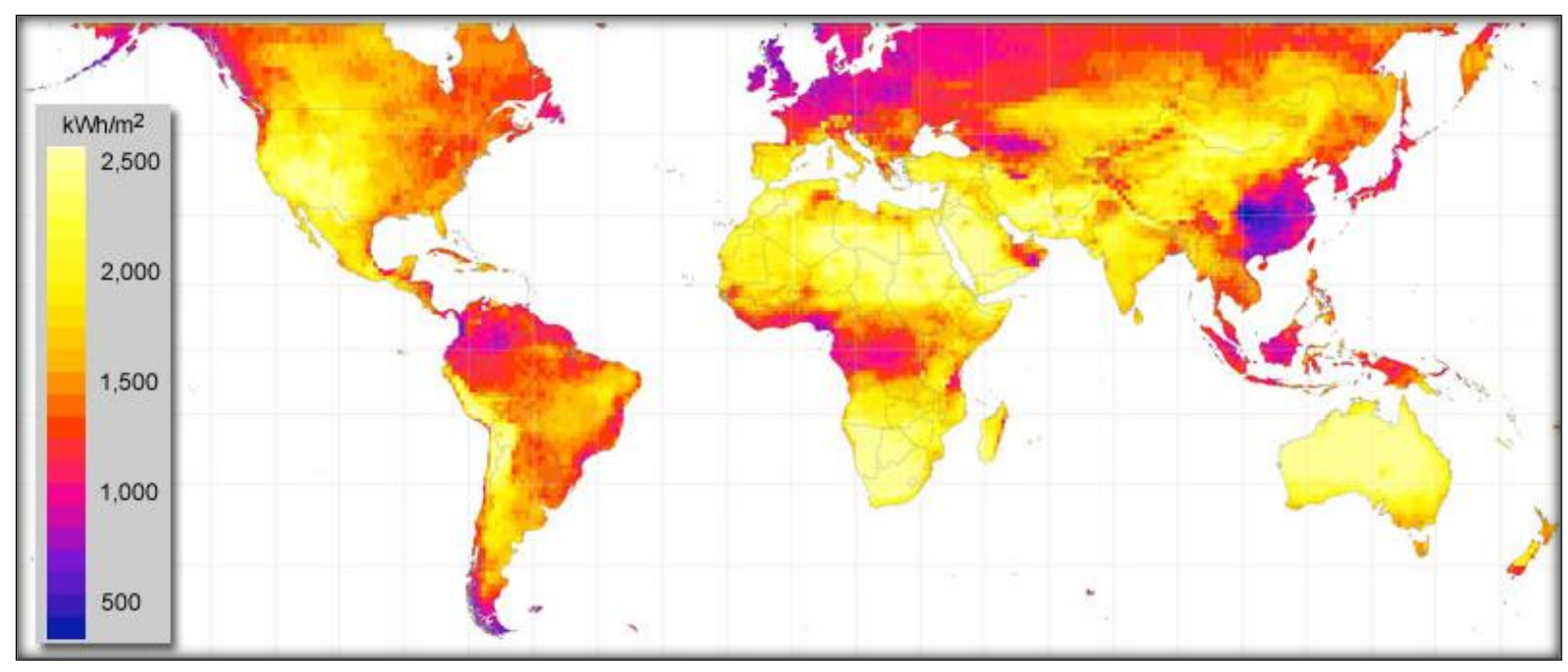

Figure 9-3 Yearly Solar Radiance[77]

Much of the heavy oil that is recovered is located in location with good solar resources. Comparing the figures above, the most suitable location for the setup of solar steam generator is California, Venezuela, Saudi Arabia, and Iraq. The graphs below show monthly mean minimum and maximum daily temperature and monthly total sun hours for suitable locations mentioned above.

California-

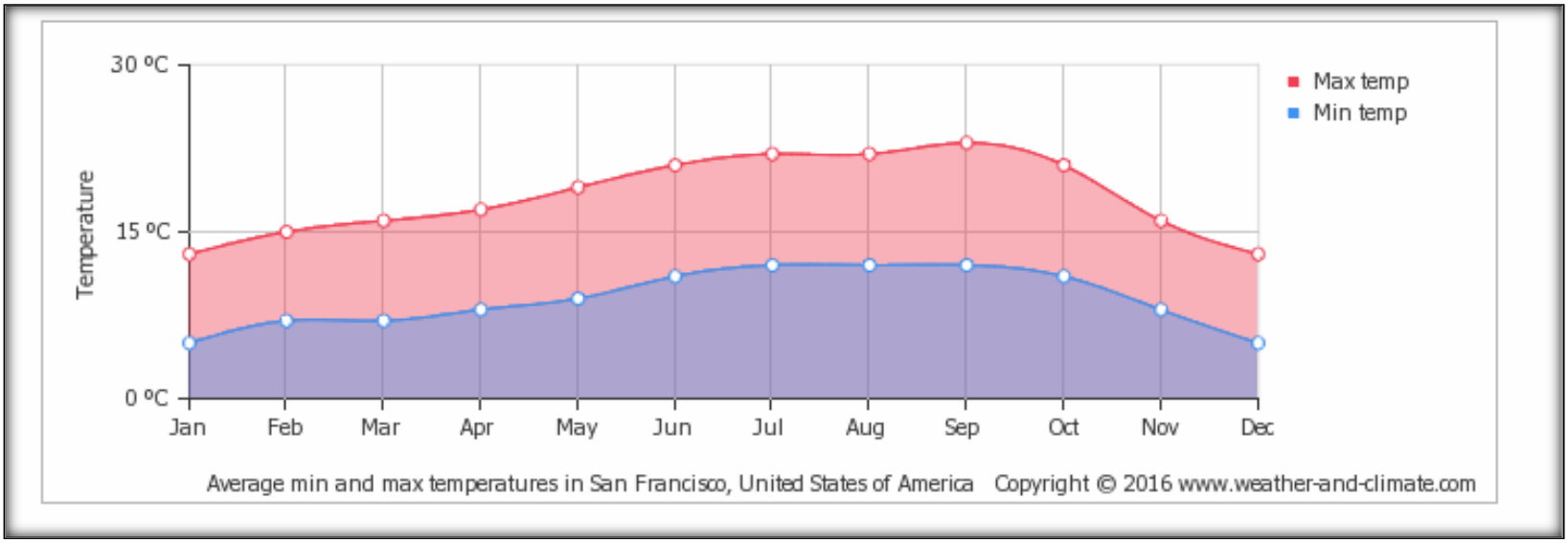

Figure 9-4 Average Minimum and Maximum Temperature in San Francisco, U.S.A 


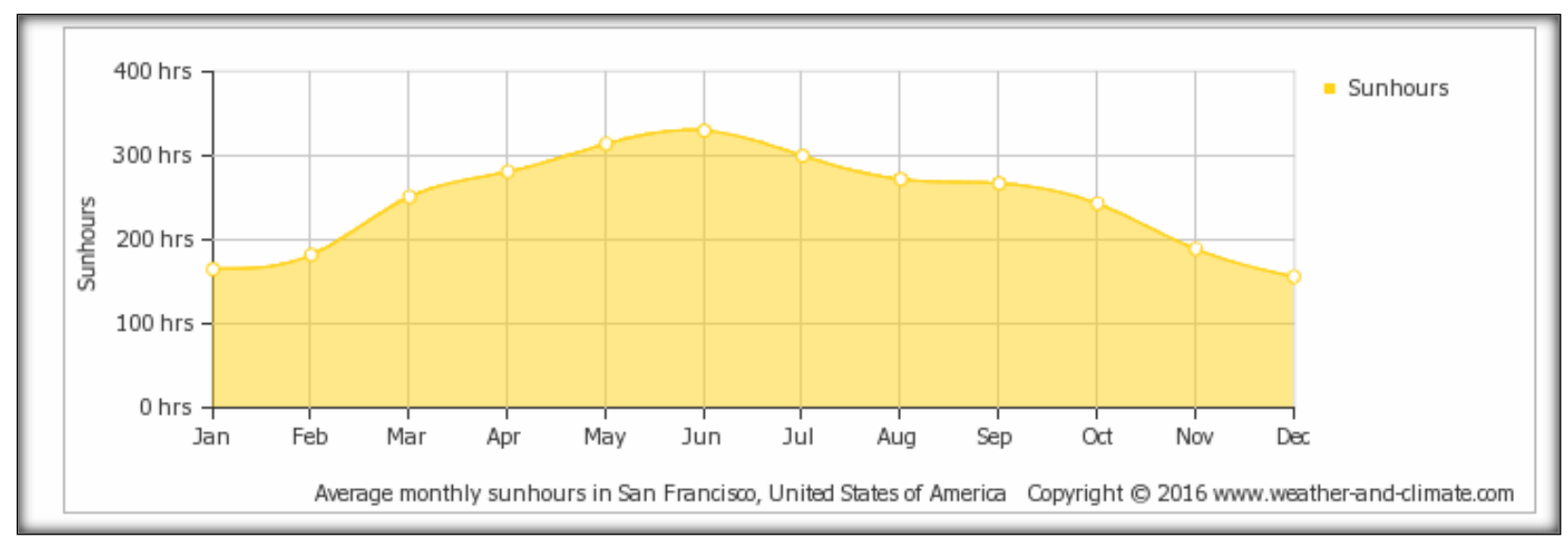

Figure 9-5 Average Monthly Sun hour in San Francisco, U.S.A [78]

\section{Venezuela}

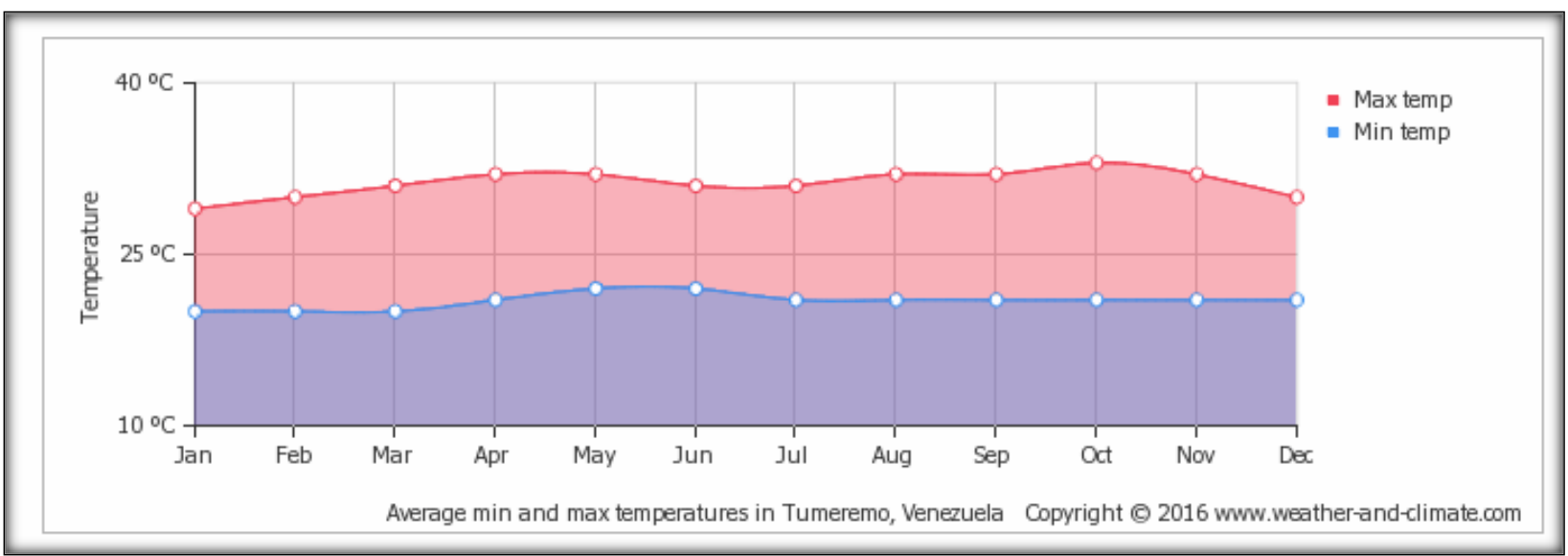

Figure 9-6 Average Minimum and Maximum Temperature in Tumeremo, Venezuela

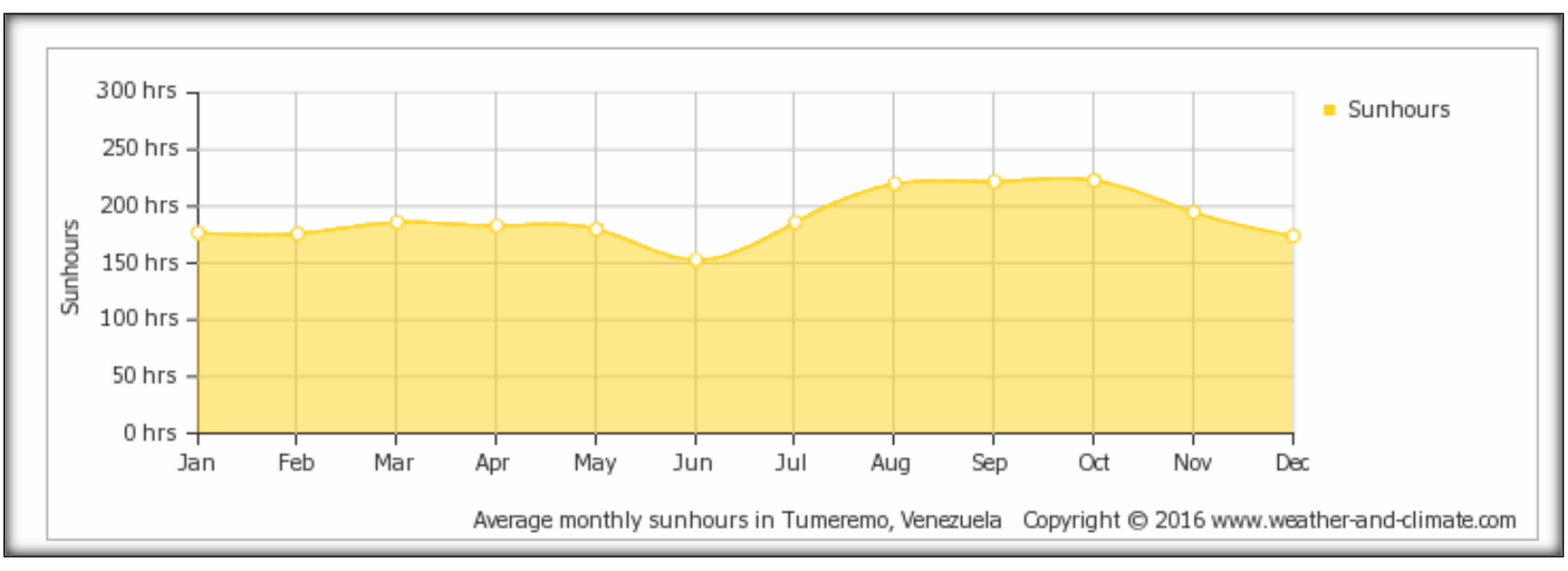

Figure 9-7 Average Monthly Sun hour in Tumeremo, Venezuela[79]

Saudi Arabia- 


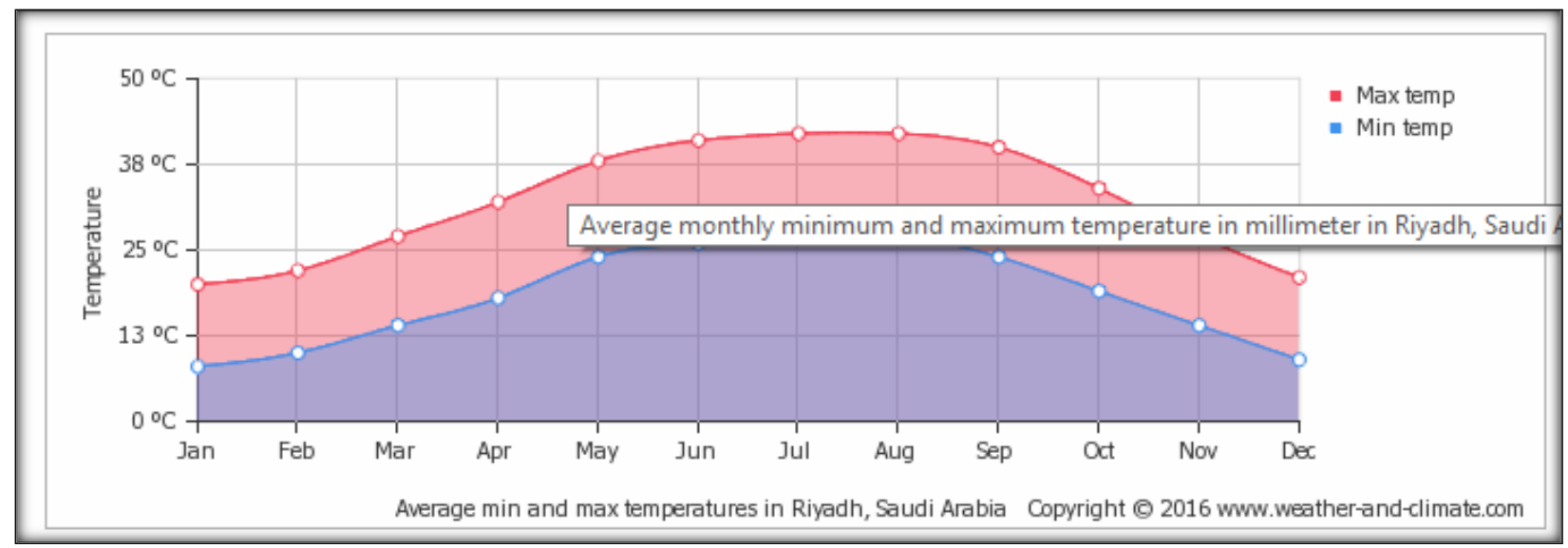

Figure 9-8 Average Minimum and Maximum Temperature in Riyadh, Saudi Arabia

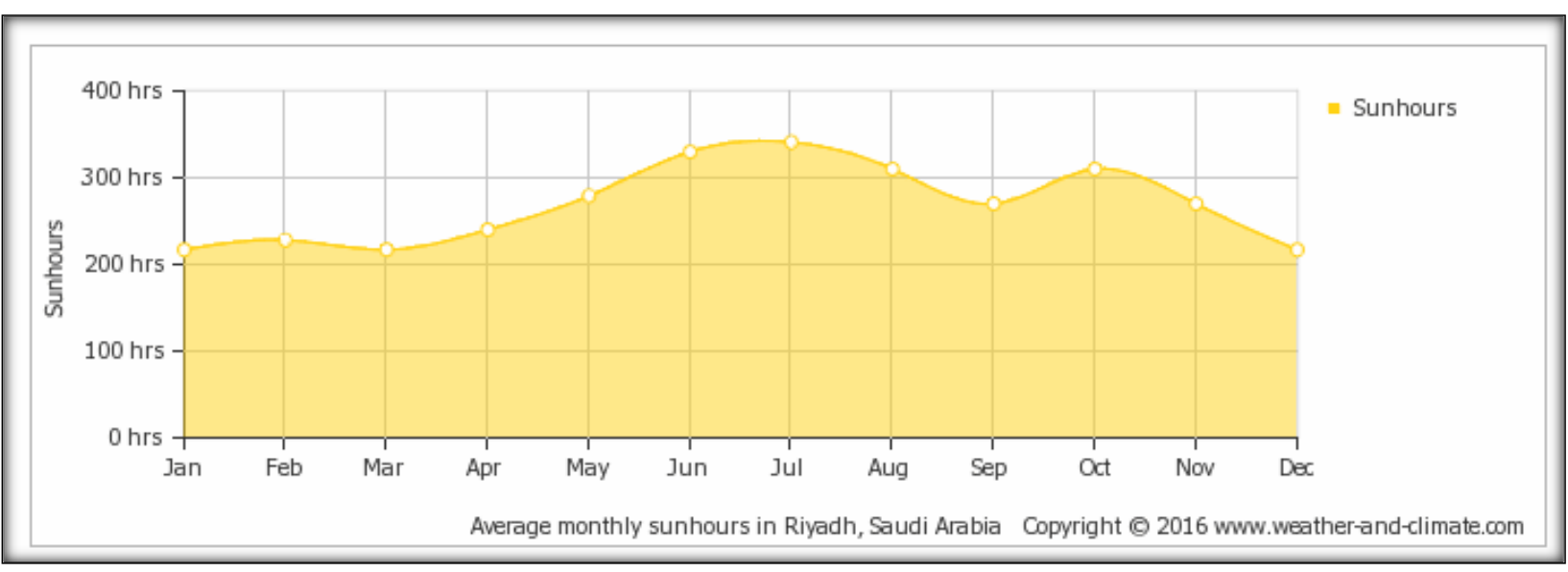

Figure 9-9 Average Monthly Sun hour in Riyadh, Saudi Arabia[80]

Iraq-

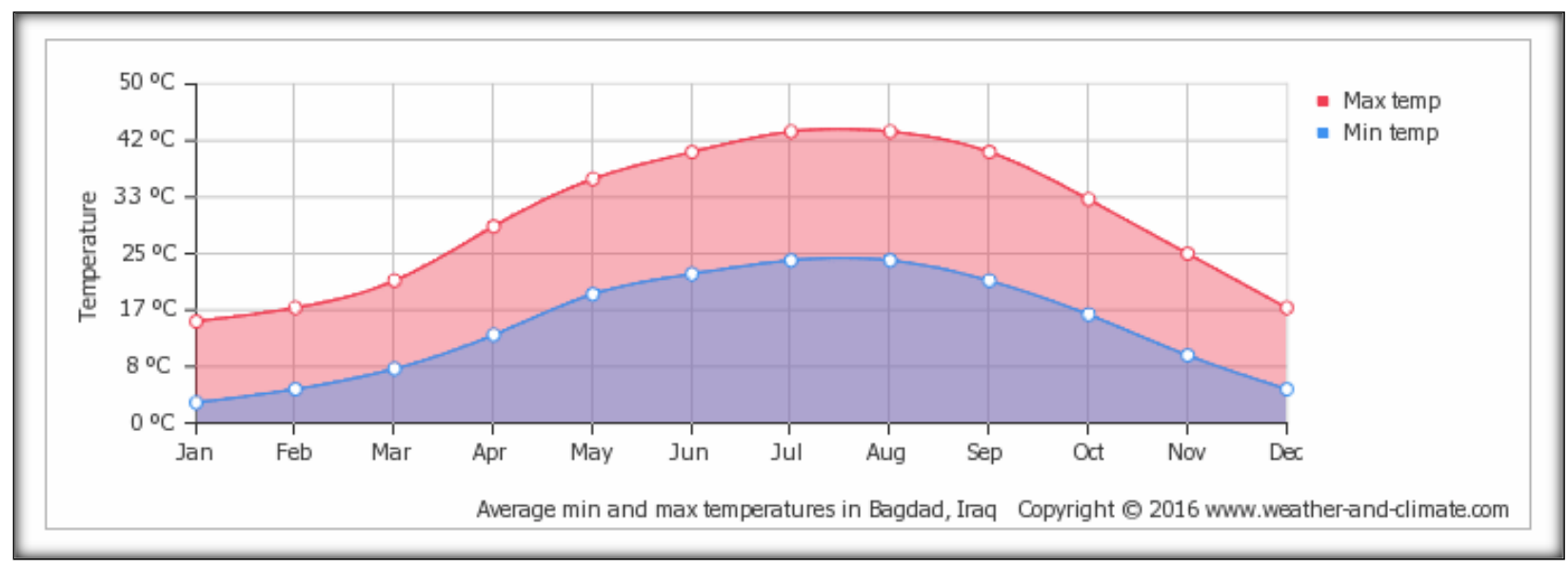

Figure 9-10 Average Minimum and Maximum Temperature in Bagdad, Iraq 


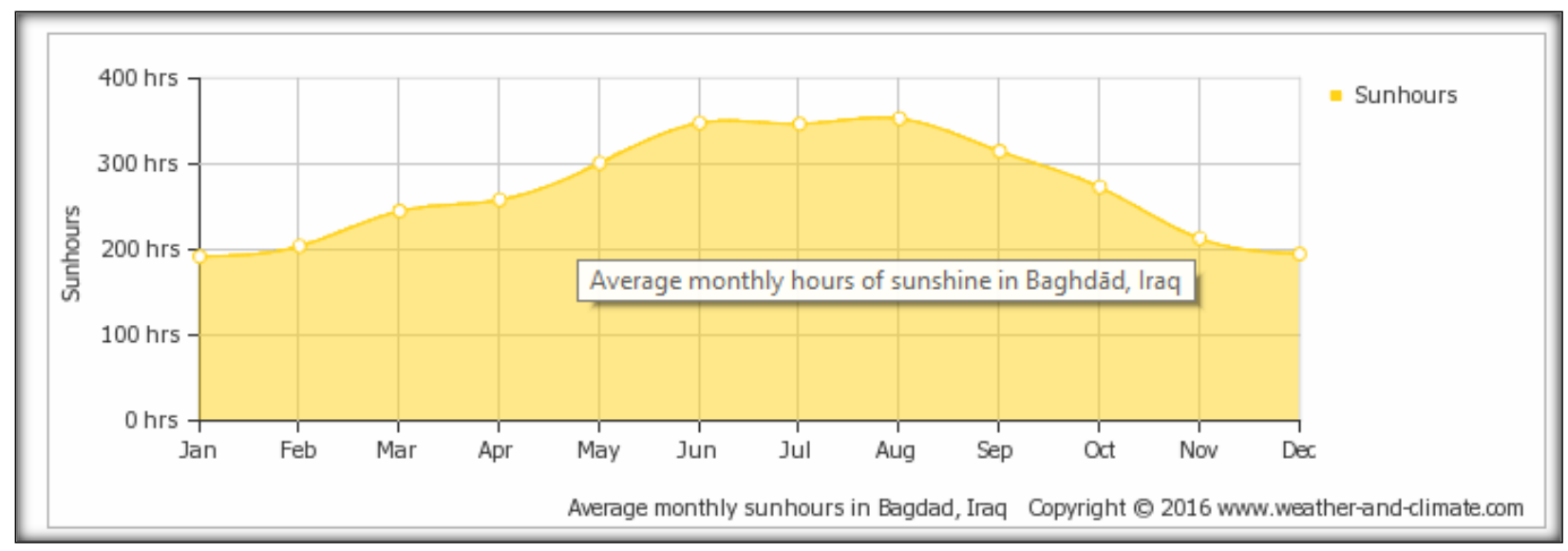

Figure 9-11 Average Monthly Sun hours in Bagdad, Iraq[81]

To find the most suitable locations for generation of steam by solar steam generators or hybrid generators, the table below compares heavy oil reserves to annual solar radiance and natural gas pricing.

\begin{tabular}{|c|c|c|c|c|}
\hline Country & Annual Solar & Heavy Oil Reserves & Natural & Price \\
\hline Russia & $1400 \mathrm{Kwh} / \mathrm{M}^{2}$ & $\begin{array}{l}\text { More than } 1 \text { trillion barrels } \\
\text { in place. }\end{array}$ & Year & $\begin{array}{l}\text { Natural Gas Spot } \\
\text { Price Dollars per } \\
\text { Million Btu [82] }\end{array}$ \\
\hline & & & 2016 & 5.16 \\
\hline & & & 2015 & 5.81 \\
\hline & & & 2014 & 10.45 \\
\hline & & & 2013 & 10.99 \\
\hline & & & 2012 & 11.64 \\
\hline Saudi Arabia & $2500 \mathrm{Kwh} / \mathrm{M}^{2}$ & $\begin{array}{l}\text { Up to } 100 \text { Billion barrels in } \\
\text { place. }\end{array}$ & Averag & \\
\hline Iraq & $2700 \mathrm{Kwh} / \mathrm{M}^{2}$ & $\begin{array}{l}\text { Up to } 100 \text { Billion barrels in } \\
\text { place. }\end{array}$ & Averag & \\
\hline Venezuela & $2100 \mathrm{Kwh} / \mathrm{M}^{2}$ & $\begin{array}{l}\text { More than } 1 \text { trillion barrels } \\
\text { in place. }\end{array}$ & Averag & \\
\hline
\end{tabular}




\begin{tabular}{|c|c|c|c|c|}
\hline \multirow[t]{6}{*}{ Canada } & \multirow[t]{6}{*}{$1700 \mathrm{Kwh} / \mathrm{M}^{2}$} & \multirow[t]{6}{*}{$\begin{array}{l}\text { More than } 1 \text { trillion barrels } \\
\text { in place. }\end{array}$} & Year & $\begin{array}{l}\text { Natural Gas Spot } \\
\text { Price Dollars per } \\
\text { Million Btu [83] }\end{array}$ \\
\hline & & & 2016 & 2.05 \\
\hline & & & 2015 & 2.64 \\
\hline & & & 2014 & 4.23 \\
\hline & & & 2013 & 3.03 \\
\hline & & & 2012 & 2.31 \\
\hline \multirow[t]{6}{*}{ U.S.A } & \multirow[t]{6}{*}{$2100 \mathrm{Kwh} / \mathrm{M}^{2}$} & \multirow[t]{6}{*}{$\begin{array}{l}\text { Up to } 100 \text { Billion barrels in } \\
\text { place. }\end{array}$} & Year & $\begin{array}{l}\text { Natural Gas Spot } \\
\text { Price Dollars per } \\
\text { Million Btu [84] }\end{array}$ \\
\hline & & & 2016 & 2.52 \\
\hline & & & 2015 & 2.62 \\
\hline & & & 2014 & 4.37 \\
\hline & & & 2013 & 3.73 \\
\hline & & & 2012 & 2.75 \\
\hline
\end{tabular}

\subsection{Advantages of Solar Enhanced Oil Recovery}

\subsubsection{Financial}

1. Operators of Solar Enhanced Oil Recovery can hedge against the fuel price volatility as solar energy is free and this could further improve the economics of oil production [85].

2. With the use of this technology, the value of natural gas is maximized. As may oil producing countries use natural gas for the EOR operation, this puts them in direct competition with industrial development. With the use of solar EOR, there will be more natural gas availability for other industry boosting the economic activity. Additionally, solar EOR reduces the gas usage by $80 \%$ [86].

3. Once installed, solar generators can produce steam for 30 years with $60 \%$ reduced operating cost [85].

\subsubsection{Technical}

1. Solar power towers are simple and easy to operate compared to gas steam generators [87]. 
2. More oil can be economically recovered compared to gas steam generators with optimized solar steam strategy of heliostat design coupled with advanced aiming controls and software [88].

\subsubsection{Social and environmental impact}

1. Solar EOR reduces nitrogen oxides and carbon emission enabling producers to expand production without being concerned about the increasing regulations and constrains from carbon legislature [89].

In future if the companies are charged for every ton of carbon emission, with the use of this technology, companies will spend a lot lesser. This technology has a positive impact on the environment.

2. Development of solar fields and wells will create more job opportunities leading to powerful economic stimulus [90].

\subsection{Disadvantages of Solar Enhanced Oil Recovery}

\subsubsection{Financial}

1. The initial installing cost and capital cost of solar power steam generator is very high compared to the gas steam generators. Additionally, it could take up to 10 to 15 years to break even with the initial investment cost [91].

\subsubsection{Technical}

1. Location of heliostat is dependent on the availability of sunlight. This plant can only be setup where the availability of sunlight is high. Areas where it remains cloudy or foggy, installing solar EOR plant is not suitable. Additionally, at night as solar energy cannot be obtained, the plant has to generate steam by natural gas [92].

2. Although there are solar storage systems attached to solar power towers, the reliability of this system is very low during the night time or less sunny days [87].

3. Most of the solar panels have only $40 \%$ efficiency as $60 \%$ of the sunlight that strikes gets wasted. Most of the upcoming technologies are focused on harnessing the wasted energy to make the system more efficient. With the increased efficiency, the price of the heliostats has gone higher [93].

4. The area needed for the installation is huge averaging of up to $9.5 \mathrm{sq} \mathrm{mi}\left(25 \mathrm{~km}^{2}\right)$. Additionally, once solar field is laid it cannot be moved [94]. 


\subsubsection{Social and environmental impact}

1. The wind condition can have a severe impact on heliostat as the operating limit is up to 25 mph wind. Anything above it can reduce the efficiency of heliostat [95].

2. For the dust, additional use of water is used by enclosed cleaning trough [96].

\subsection{Advantages of Natural Gas Enhanced Oil Recovery}

\subsubsection{Financial}

1. The production of steam by natural gas is very cheap compared to the solar production of steam as the installation cost is significantly less. Additionally, the technological advancement in shale has made natural gas easy to recover in large quantity, making it cheaper [97].

\subsubsection{Technical}

1. Natural gas is easy to be stored in salt formations and aquifer reservoirs or transported by tankers and pipelines. This makes it more reliable to produce steam in different weather conditions during day and night [98].

2. Less space is required compared to solar EOR for the setup of Heat Recovery Steam Generators [97].

3. The efficiency of natural gas steam generators is very high of up to $85 \%$ [99].

9.4.3 Social and environmental impact

1. Compared to fossil fuel such as coal, natural gas produces $50 \%$ less carbon emission [100].

2. In the U.S, as technological advancement has unlocked enough natural gas jobs. This industry supports more than 2.8 million jobs in the U.S [101].

\subsection{Disadvantages of Natural Gas Enhanced Oil Recovery}

\subsubsection{Financial}

1. Operators of Natural Gas Enhanced Oil Recovery cannot hedge against the fuel price volatility as natural gas is not free and this could affect the economics of oil production [102]. The operating cost is higher in the Steam production by natural gas compared to steam produced by solar power. 


\subsubsection{Technical}

1. As natural gas is odorless, the leaks can go undetected further causing explosion. This can be extremely toxic when inhaled. Production of methane is 21 times more dangerous than carbon dioxide.

2. For using the natural gas to further produce steam, processing is needed which further produces sulfur, water vapor, carbon dioxide, and even helium and nitrogen.

\subsubsection{Social and environmental impact}

1. Natural gas is nonrenewable source of energy and cannot be considered long tem supply solution as compared to solar energy [103].

2. Although natural gas emits $50 \%$ less carbon dioxide than other fossil fuels, it considerably has more carbon emissions when compared to solar energy.

3. Natural gas is a source of terrorism and violence. Gas investigation happens in nations with the most noticeably bad records of fascism, for example, the Middle East, and African nations. The income from characteristic gas deal discovers route into pockets of these despots who gather trillions of dollars. This marvel drives up savagery as oil and gas cash wind up in the hands of terrorists [98]. 


\section{Chapter 10 CONCLUSION}

With the drop in the prices of oil, investments in technology have significantly dropped. However, investment in innovation is needed as less investment today means less of future supply. With low investment cost, the future exploration and recovery cost of oil will not drop and would bring companies back to the beginning of the cycle [104]. This project focuses on highlighting an appropriate technology, solar wells, that oil industry can consider for investment. Solar steam generators operates from the solar power and compared to HRSG, have low ongoing operation and maintenance cost. Solar generators can be upgraded as per the company's demand and are modular. If more steam is to be generated, more heliostats are added. They also have 3 important components, which are comparatively fewer than HRSG and requires low maintenance including quick wash in a year or two. Further, in order to pursue companies to invest in the solar steam generators for the recovery of heavy oil, it is compared to the steam generators run by natural gas. In order to compare these two generator systems, the goal is to find the cost of steam production by both these methods to support the comparison. The investment cost in solar steam generator is almost 3 times higher than that natural gas generator however, operation and maintenance cost of natural gas is approximately 9 times higher than that of solar generators. As both these plants have their own pros and cons, a combination of these two system can be considered. The hybrid system can bring down the cost of solar steam generation making it environmental friendly. When the prices of natural gas increase, the price difference for the setup of combination system vs HRSG will not be much apart. Hence, the recommendations are made to big oil companies to invest on a combined systems and with time and increased cash flow, expand into SSG setup. The NPV calculation shows that the solar investment have a negative return up until 14 years and natural gas generators gets their positive return starting $2^{\text {nd }}$ year. Based on this result, HRSG are profitable but SSG are environmental friendly. Comparing the countries above from the discussion chapter, best possible locations for the setup of hybrid plant are Saudi Arabia, Iraq, Venezuela, and U.S.A as they have high Annual Solar radiance with high heavy oil resources and low natural gas prices. 


\section{References}

[1] U.S. Geological Survey, "The Significance of Field Growth and the Role Enhanced Oil Recovery,” 2000. [Online]. Available: https://pubs.er.usgs.gov/publication/fs11500

[2] "What is the Difference between Primary, Secondary \& Enhanced Recovery for Oil Extraction?," PETRO Industry News, 2014. [Online]. Available: https://www.petroonline.com/news/fuel-for-thought/13/breaking-news/what-is-the-difference-betweenprimary-secondary-amp-enhanced-recovery-for-oil-extraction/31405.

[3] I. Faergestad, "Heavy Oil," 2016. [Online]. Available: http://www.slb.com//media/Files/resources/oilfield_review/defining_series/Defining-HeavyOil.pdf?la=en\&hash=40B7EA5DDB2A326F26E3206840785C844F5ABB70

[4] “API gravity.” [Online]. Available: http://www.petroleum.co.uk/api.

[5] D. Law, "A New Heavy Oil Recovery Technology to Maximize Performance and to Maximize Performance and Minimize Environmental Impact,” 2011. [Online]. Available: http://www.spe.org/dl/docs/2011/Law.pdf

[6] M. Foroozanfar, "ENHANCED HEAVY OIL RECOVERY BY USING THERMAL AND NON-THERMAL METHODS," IIOAB, 2016. [Online]. Available: http://www.iioab.org/articles/IIOABJ_7.S5_92-104.pdf

[7] S. Salem, G. Abdelaleem, N. Elsayed, and W. O. Saad, "IMPROVING THE QALITY OF PETROLEUM CRUDE OILS BY DEASPHALTING,” Eng. Sci., 2011. [Online]. Available: http://www.aun.edu.eg/journal_files/82_J_8822.pdf

[8] S. A. A. NAQVI, "ENHANCED OIL RECOVERY OF HEAVY OIL BY USING THERMAL AND NON-THERMAL METHODS,” Dalhousie University, 2012.

[9] G. Zerkalov, "Steam Injection for Enhanced Oil Recovery,” 2015. [Online]. Available: http://large.stanford.edu/courses/2015/ph240/zerkalov2/

[10] “Steam Injection.” [Online]. Available: http://www.belgravecorp.com/steaminjection.

[11] R. G. Santos, W. Loh, A. C. Bannwar, and O. V. Trevisan, "An overview of heavy oil properties and its recovery and transportation methods," Brazilian J. Chem. Eng., 2014.

[12] K. Alnoaimi, "Heavy Oil Recovery: Definitions and Means," 2010. [Online]. Available: http://large.stanford.edu/courses/2010/ph240/alnoaimi1/

[13] J. P. Everett and C. F. Weinaug, "Physical Properties of Eastern Kansas Crude Oils," Kansas Geol. Surv., 1955. [Online]. Available: 
http://www.kgs.ku.edu/Publications/Bulletins/114_7/

[14] A. Muggeridge et al., "Recovery rates, enhanced oil recovery and technological limits," Philos Trans A Math Phys Eng Sci, 2006. [Online]. Available: https://www.ncbi.nlm.nih.gov/pmc/articles/PMC3866386/

[15] A. Daryasafar, A. Ahadi, and R. Kharrat, "Modeling of Steam Distillation Mechanism during Steam Injection Process Using Artificial Intelligence," Sci. World, 2014. [Online]. Available: https://www.hindawi.com/journals/tswj/2014/246589/

[16] M. T. Vafaei, R. Eslamloueyan, L. Enfeali, and S. Ayatollahi, "Analysis and Simulation of Steam Distillation Mechanism during the Steam Injection Process," Am. Chem. Soc., 2008. [Online]. Available: http://pubs.acs.org/doi/full/10.1021/ef800602w

[17] "Relative permeability." [Online]. Available: http://petrowiki.org/Relative_permeability.

[18] "Steam Flooding." [Online]. Available: http://www.mktechsolutions.com/Steam.html.

[19] J. G. Speight, Enhanced Recovery Methods for Heavy Oil and Tar Sands. 2009.

[20] J. Alvarez and S. Han, "Current Overview of Cyclic Steam Injection Process," Pet. Sci. Res., 2013.

[21] “Thermal Enhanced Oil Recovery Process." [Online]. Available: http://petroleumsupport.com/thermal-enhanced-oil-recovery-process/.

[22] J. DOWNEY, "UNDERSTANDING SAGD TECHNOLOGY.” [Online]. Available: http://jeromedowney.ca/blog/understanding-sagd/\#more-3812.

[23] “About Tar Sands.” [Online]. Available: http://ostseis.anl.gov/guide/tarsands/.

[24] "UNCONVENTIONAL." [Online]. Available: http://www.conocophillips.ca/technologyand-innovation/unconventional/Pages/sagd.aspx.

[25] “Mechanism." [Online]. Available: http://petrowiki.org/File:Vol5_Page_1355_Image_0001.png.

[26] “Steam-assisted gravity drainage." [Online]. Available: https://en.wikipedia.org/wiki/Steam-assisted_gravity_drainage.

[27] H. Zarza, E., Valenzuela, L., León, J., Hennecke, K., Eck, M., Weyers, H.D., Eickhoff, "Direct steam generation in parabolic troughs: Final results and conclusions of the DISS project," Energy, vol. 29, no. 5-6, pp. 635-644, 2004.

[28] “Solar Thermal Power Plants." [Online]. Available: https://www.eia.gov/energyexplained/?page=solar_thermal_power_plants\#SolarPowerTo 
wers.

[29] “Solar EOR.” [Online]. Available: http://petrowiki.org/Solar_EOR.

[30] M. TRIMARCHI, "How Solar Thermal Power Works.” [Online]. Available: http://science.howstuffworks.com/environmental/green-tech/energy-production/solarthermal-power1.htm.

[31] “Concentrating Solar Power.” [Online]. Available: http://www.seia.org/policy/solartechnology/concentrating-solar-power.

[32] M. Chaar, M. Venetos, J. Dargin, and D. Palmer, "Economics Of Steam Generation For Thermal EOR," 2014.

[33] E. C. Donaldson, G. V. Chilingarian, and T. F. Yen, Enhanced Oil Recovery, II, Processes and Operations. 1989.

[34] "Heat recovery steam generator." [Online]. Available: https://en.wikipedia.org/wiki/Heat_recovery_steam_generator.

[35] “Once Through Steam Generators.” [Online]. Available: http://inproheat.com/product/heat-recovery-steam-generators/natural-circulation-heatrecovery-steam-generators-behind-gas.

[36] “PRODUCING THERMAL EOR IN US.” [Online]. Available: http://www.ogj.com/content/dam/ogj/print-articles/Volume 110/April 2/Producing Thermal EOR.pdf.

[37] “Companies Using Enhanced Oil Recovery." [Online]. Available: http://www.cafrackfacts.org/fracking-in-california/who-is-fracking-in-california/.

[38] “Belridge.”[Online]. Available: http://www.aeraenergy.com/belridge.asp.

[39] “Coalinga.” [Online]. Available: http://www.aeraenergy.com/coalinga.asp.

[40] "Midway Sunset." [Online]. Available: http://www.aeraenergy.com/midway-sunset.asp.

[41] “San Ardo.” [Online]. Available: http://www.aeraenergy.com/san-ardo.asp.

[42] “Aera Energy LL." [Online]. Available: https://www.grac.org/media/files/files/c7f39f35/4.4_Morris.pdf.

[43] A. Amarnath, "Enhanced Oil Recovery Scoping Study," 1999. [Online]. Available: http://www.energy.ca.gov/process/pubs/electrotech_opps_tr113836.pdf

[44] E. WALDNER, "Kern pumping oil, but Shell says production on decline," 2006. [Online]. Available: http://www.bakersfield.com/news/business/kern-pumping-oil-but-shell-says- 
production-on-decline/article_1835dd4b-4e6f-5aba-ba5f-e33af3dc28a2.html

[45] "ClearSign Contracts with Aera Energy LLC to Demonstrate Next-Generation NOx Emissions Control Technology in California's San Joaquin Valley.” [Online]. Available: http://www.marketwatch.com/story/clearsign-contracts-with-aera-energy-llc-todemonstrate-next-generation-nox-emissions-control-technology-in-californias-sanjoaquin-valley-2014-08-19-92031548.

[46] T. Dorsey, "ClearSign Combustion Has Successful Operational Employment Of Duplex Burner.” [Online]. Available: https://seekingalpha.com/article/3467636-clearsigncombustion-successful-operational-employment-duplex-burner.

[47] M. Hsia-Coron, "Monterey County’s Oil Fields," 2016. [Online]. Available: http://scruzclimact.pbworks.com/w/file/fetch/104880520/Report_Monterey_County_Oil_ \%26_Gas_Fields.pdf

[48] C. Nelder, "Heavy Oil of the Kern River Oil Field," 2011. [Online]. Available: http://www.getreallist.com/heavy-oil-of-the-kern-river-oil-field.html.

[49] “Chevron Announces Minas Surfactant Flood Pilot Start Up,” 2013. [Online]. Available: http://www.chevronindonesia.com/en/news/minas_surfactant.aspx.

[50] “Duri Field Expansion, Sumatra, Indonesia.” [Online]. Available: http://www.hydrocarbons-technology.com/projects/duri-field-expansion-sumatra/.

[51] “California Oil \& Gas Company.” [Online]. Available: http://aoghs.org/stocks/californiaoil-gas-company/.

[52] "COALINGA.” [Online]. Available: http://www.brightsourceenergy.com/coalinga\#.WTcdQ2jyvIU.

[53] 'Chevron Technology Ventures Launches World's Largest Solar Enhanced-Oil-Recovery Project.” [Online]. Available: https://www.chevron.com/stories/chevron-technologyventures-launches-worlds-largest-solar-enhancedoilrecovery-project “UNITED STATES SECURITIES AND EXCHANGE COMMISSION Berry Petroleum," 1934.

[55] “Berry Petroleum EOR plant." [Online]. Available: http://cspworld.org/cspworldmap/berry-petroleum-eor-plant.

[56] “GlassPoint Berry Petroleum.” [Online]. Available: https://www.glasspoint.com/berrypetroleum/. 
[57] "PDO taps GlassPoint for solar EOR system to boost oil production in Oman," PennEnergy, 2011.

[58] “Heliostats 101." [Online]. Available: http://www.esolar.com/products/heliostats/.

[59] A. S. Blazev, Photovoltaics for Commercial and Utilities Power Generation. 2011.

[60] W. B. Stine and M. Geye, Power From The Sun. 2001.

[61] M. Günther, M. Joemann, and S. Csambor, "Parabolic Trough Technology," in Advanced CSP Teaching Materials, [Online]. Available:

http://edge.rit.edu/edge/P15484/public/Detailed Design Documents/Solar Trough

Preliminary analysis references/Parabolic Trough Technology.pdf

[62] "What is Solar Enhanced Oil Recovery?" [Online]. Available:

http://www.solartronenergy.com/applications/solar-enhanced-oil-recovery-with-solarconcentrator/.

[63] "HEAT RECOVERY STEAM GENERATOR." [Online]. Available: https://www.myodesie.com/wiki/index/returnEntry/id/2994\#Economizer.

[64] "Working principle of Economizer," 2016. [Online]. Available: http://www.readorrefer.in/article/Working-principle-of-Economizer_5570/.

[65] “7F USERS GROUP, HRSG SPOTLIGHT SESSION Mitigate fatigue cracking in HRSGs." [Online]. Available: http://www.ccj-online.com/2q_2012-outage-handbook/7fusers-group/7f-users-group-hrsg-spotlight-session/.

[66] "Feed Water and Steam Circuit of Boiler." [Online]. Available: https://www.electrical4u.com/feed-water-and-steam-circuit-of-boiler/.

[67] "Forced Circulation." [Online]. Available: http://nawabi.de/project/hrsg/page7_1.htm.

[68] “Thermosyphon(Natural) Circulation.” [Online]. Available: http://nawabi.de/project/hrsg/page7_1.htm.

[69] "Steam Boiler All of About Steam Boiler, Heat Exchanger, Energy and Power Generation.” [Online]. Available: http://steamofboiler.blogspot.com/2011/08/hrsgcomponents.html.

[70] K. Korosec, “Chevron uses solar power to produce more oil," ZDNet, 2011. [Online]. Available: http://www.zdnet.com/article/chevron-uses-solar-power-to-produce-more-oil/

[71] “INDUSTRIAL-DUTY DESIGN GT-HRSG POWER UTILITY.” [Online]. Available: https://victoryenergy.com/enhanced-heat-recovery/gt-hrsg-power-utility/. 
[72] R. Saunders, "MAKING STEAM FROM SOLAR ENERGY for Small Steam Turbines and Engines," 2008.

[73] “Calculator: Superheated Steam Table." [Online]. Available: http://www.tlv.com/global/TI/calculator/superheated-steam-table.html.

[74] "How To Calculate The True Cost of Steam." [Online]. Available: https://www.energy.gov/sites/prod/files/2014/05/f15/tech_brief_true_cost.pdf.

[75] “RENEWABLE ENERGY TECHNOLOGIES: COST ANALYSIS SERIES," 2012.

[76] D. Pauschert, "Study of Equipment Prices in the Power Sector," 2009.

[77] “Annual Solar Irradiance, Intermittency and Annual Variations.” [Online]. Available: http://www.greenrhinoenergy.com/solar/radiation/empiricalevidence.php.

[78] "AVERAGE MONTHLY WEATHER IN SAN FRANCISCO, UNITED STATES OF AMERICA.” [Online]. Available: https://weather-and-climate.com/average-monthlyRainfall-Temperature-Sunshine,San-Francisco,United-States-of-America.

[79] “AVERAGE MONTHLY WEATHER IN TUMEREMO, VENEZUELA.” [Online]. Available: https://weather-and-climate.com/average-monthly-Rainfall-TemperatureSunshine,Tumeremo, Venezuela.

[80] “AVERAGE MONTHLY WEATHER IN RIYADH, SAUDI ARABIA.” [Online]. Available: https://weather-and-climate.com/average-monthly-Rainfall-TemperatureSunshine,Riyadh,Saudi-Arabia.

[81] “AVERAGE MONTHLY WEATHER IN BAGDAD, IRAQ.” [Online]. Available: https://weather-and-climate.com/average-monthly-Rainfall-TemperatureSunshine,Bagdad,Iraq.

[82] "Index Mundi Russian Natural Gas Monthly Price - US Dollars per Million Metric British Thermal Unit.” [Online]. Available: http://www.indexmundi.com/commodities/?commodity=russian-natural-gas\&months=60.

[83] “Chart-3-Natural-Gas-Price-new." [Online]. Available: http://www.cga.ca/wpcontent/uploads/2017/07/Chart-3-Natural-Gas-Price-new.pdf.

[84] “U.S. EIA Henry Hub Natural Gas Spot Price." [Online]. Available: https://www.eia.gov/dnav/ng/hist/rngwhhdm.htm.

[85] “GlassPoint California." [Online]. Available: https://www.glasspoint.com/markets/california/. 

2013. [Online]. Available: https://www.glasspoint.com/new-research-validatesglasspoints-solar-eor-technology/

[87] M. Hatti, "Operation and Maintenance Methods in Solar Power Plants," Green Energy Technol., 2014.

[88] Y. Gilon and Is. Kroizer, "Method and control system for operating a solar power tower system US 20090217921 A1,” 2008. [Online]. Available:

https://www.google.com/patents/US20090217921

[89] A.-C. Aycaguer, M. Lev-On, and A. M. Winer, "Reducing Carbon Dioxide Emissions with Enhanced Oil Recovery Projects: A Life Cycle Assessment Approach," Am. Chem. Soc., 2001. [Online]. Available: http://pubs.acs.org/doi/full/10.1021/ef000258a

[90] P. Gillespie, "Solar energy jobs double in 5 years," 2016. [Online]. Available: http://money.cnn.com/2016/01/12/news/economy/solar-energy-job-growth-useconomy/index.html

[91] C. A. Rodriguez, M. A. Modestino, D. Psaltis, and C. Moser, "Design and cost considerations for practical solar-hydrogen generators," R. Soc. Chem., 2014. [Online]. Available: http://pubs.rsc.org/en/content/articlehtml/2014/ee/c4ee01453g

[92] “Concentrated Solar Power and Kerala's Solar Roof Top Program," 2013. [Online]. Available: https://issuu.com/energyblitz/docs/2013_1_.

[93] K. Valentine, "Solar Technique Achieves Record-High 40\% Efficiency," 2014. [Online]. Available: https://thinkprogress.org/solar-technique-achieves-record-high-40-efficiency20211e23fdbf

[94] V. WOOLLASTON, "How many solar panels would it take to power the PLANET? Experts reveal we would need to cover an area the size of Spain to provide the world with enough energy,” 2015. [Online]. Available:

http://www.dailymail.co.uk/sciencetech/article-3263721/How-solar-panels-powerPLANET-Experts-reveal-need-cover-area-size-Spain-provide-world-energy.html

[95] “Heliostat Wind Mitigation." [Online]. Available: https://www.google.org/pdfs/google_heliostat_wind_mitigation.pdf

[96] “Solar Water Heating System Maintenance and Repair." [Online]. Available: https://energy.gov/energysaver/solar-water-heating-system-maintenance-and-repair. 
[97] "What are the advantages and disadvantages of steam and gas turbine power plants?" [Online]. Available: https://www.quora.com/What-are-the-advantages-and-disadvantagesof-steam-and-gas-turbine-power-plants.

[98] “Advantages and Disadvantages of Natural Gas." [Online]. Available: http://www.conserve-energy-future.com/advantages-and-disadvantages-of-naturalgas.php.

[99] M. Pace, "High Efficiency Heating."

[100] "Environmental Impacts of Natural Gas." [Online]. Available: http://www.ucsusa.org/clean-energy/coal-and-other-fossil-fuels/environmental-impactsof-natural-gas\#.WUWSEWjyvIV

[101] S. K. Schwartz, "Can the Natural Gas Sector Save the US Economy?," 2012. [Online]. Available: http://www.cnbc.com/id/47280026?view=story\& \$DEVICE $\$=$ native-androidmobile

[102] S. Heisler, "Oil and Gas Production : Emergence of Solar Enhanced Oil Recovery," 2010. [Online]. Available: https://www.oilandgasiq.com/gas-oil-production-andoperations/articles/how-the-sun-will-shine-for-the-oil-industry-the-em/

[103] A. K, "Pros and Cons of Natural Gas Use," 2014. [Online]. Available: http://www.brighthubengineering.com/power-plants/114797-pros-and-cons-of-naturalgas-use/

[104] S. Gross, "Energy innovation doesn't stop when oil prices are low," 2017. [Online]. Available: https://www.brookings.edu/blog/planetpolicy/2017/03/15/energy-innovationdoesnt-stop-when-oil-prices-are-low/. 